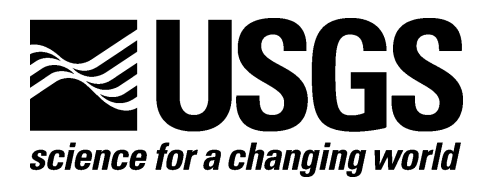

\title{
Chronology and References of Volcanic Eruptions and Selected Unrest in the United States, 1980- 2008
}

By Angela K. Diefenbach, Marianne Guffanti, and John W. Ewert

Open-File Report 2009-1118

U.S. Department of the Interior

U.S. Geological Survey 


\section{U.S. Department of the Interior \\ KEN SALAZAR, Secretary}

U.S. Geological Survey

Suzette M. Kimball, Acting Director

U.S. Geological Survey, Reston, Virginia: 2009

For product and ordering information:

World Wide Web: http://www.usgs.gov/pubprod

Telephone: 1-888-ASK-USGS

For more information on the USGS—-the Federal source for science about the Earth, its natural and living resources, natural hazards, and the environment:

World Wide Web: http://www.usgs.gov

Telephone: 1-888-ASK-USGS

Suggested citation

Diefenbach, A.K., Guffanti, M., and Ewert, J.W., 2009, Chronology and references of volcanic eruptions and selected unrest in the United States, 1980-2008: U.S. Geological Survey Open-File Report 2009-1118, 85 p. [http://pubs.usgs.gov/of/2009/1118/].

Any use of trade, product, or firm names is for descriptive purposes only and does not imply endorsement by the U.S. Government.

Although this report is in the public domain, permission must be secured from the individual copyright owners to reproduce any copyrighted material contained within this report. 


\section{Contents}

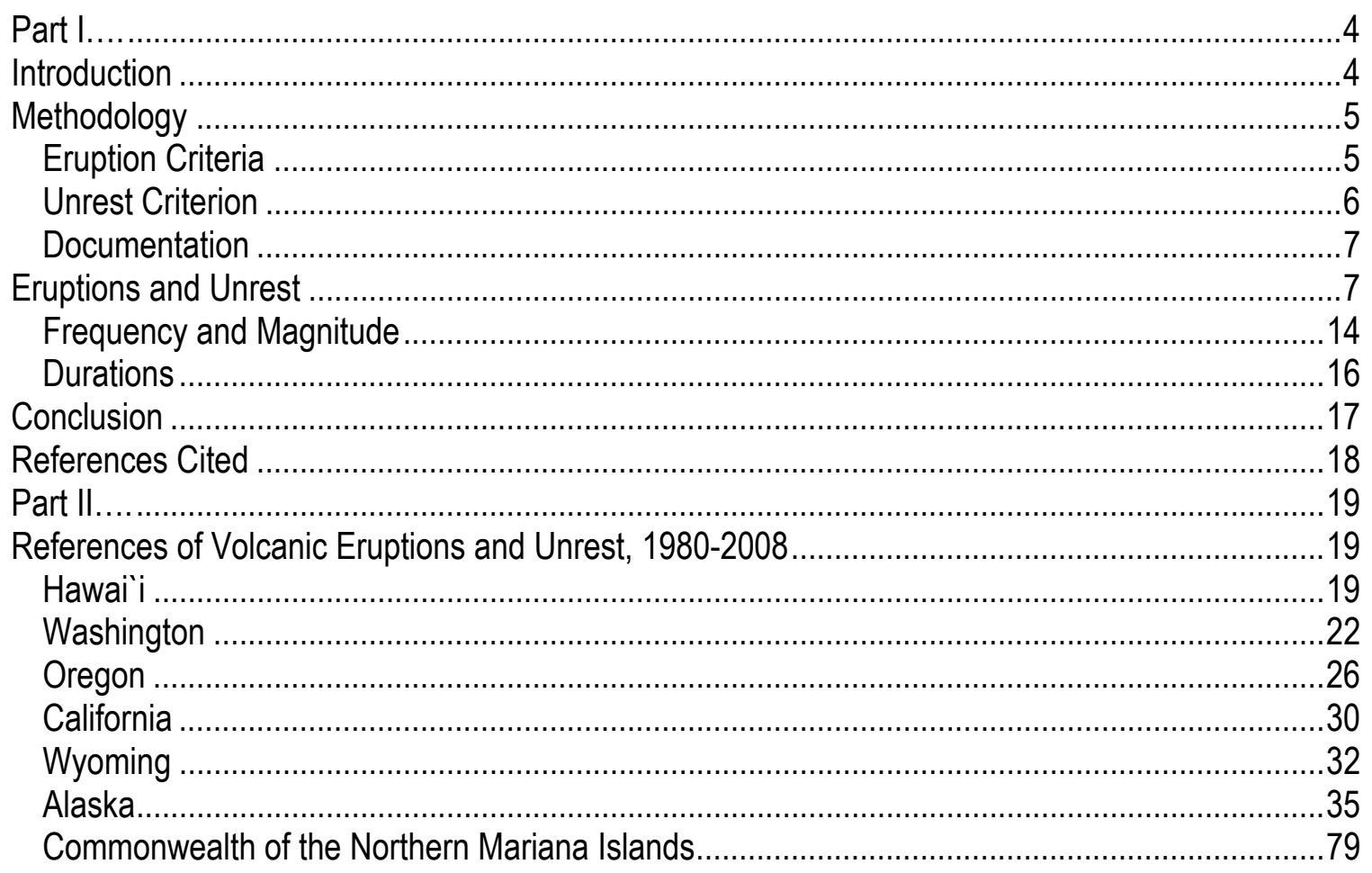

\section{Figures}

Figure 1. Geographic distribution of volcanoes in the United States ..........................................5

Figure 2. Timeline of eruptions and unrest that occurred from 1980 to 2008 at U.S. volcanoes. ...13

Figure 3. Number of volcanic eruptions and episodes of unrest that occurred during the course of

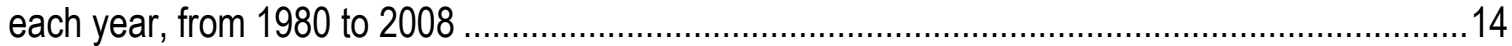

Figure 4. Interferogram of active surface deformation at South Sister volcano in central

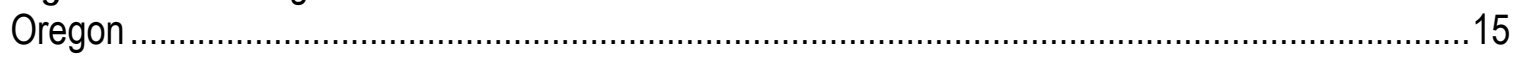

Figure 5. Frequency and magnitude of eruptions from 1980 to 2008 at U.S. volcanoes ................16

Figure 6. Frequency histogram of duration of eruptions .......................................................17

\section{Tables}

Table 1. Description and chronology of eruptions and unrest in the United States during 1980 through 2008 


\title{
Chronology and References of Volcanic Eruptions and Selected Unrest in the United States, 1980- 2008
}

\author{
By Angela K. Diefenbach ${ }^{1}$, Marianne Guffanti ${ }^{2}$, and John W. Ewert ${ }^{1}$
}

\section{Part I}

\section{Introduction}

The United States ranks as one of the top countries in the world in the number of young, active volcanoes within its borders. The United States, including the

Commonwealth of the Northern Mariana Islands, is home to approximately 170 geologically active (age $<10,000$ years) volcanoes (Siebert and Simkin, 2002-). As our review of the record shows, 30 of these volcanoes have erupted since 1980, many repeatedly. In addition to producing eruptions, many U.S. volcanoes exhibit periods of anomalous activity, unrest, that do not culminate in eruptions.

Monitoring volcanic activity in the United States is the responsibility of the U.S. Geological Survey (USGS) Volcano Hazards Program (VHP) and is accomplished with academic, Federal, and State partners. The VHP supports five Volcano Observatoriesthe Alaska Volcano Observatory (AVO), Cascades Volcano Observatory (CVO), Yellowstone Volcano Observatory (YVO), Long Valley Observatory (LVO), and Hawaiian Volcano Observatory (HVO). With the exception of HVO, which was established in 1912, the U.S. Volcano Observatories have been established in the past 27 years in response to specific volcanic eruptions or sustained levels of unrest. As understanding of volcanic activity and hazards has grown over the years, so have the extent and types of monitoring networks and techniques available to detect early signs of anomalous volcanic behavior. This increased capability is providing us with a more accurate gauge of volcanic activity in the United States.

The purpose of this report is to (1) document the range of volcanic activity that U.S. Volcano Observatories have dealt with, beginning with the 1980 eruption of Mount St. Helens, (2) describe some overall characteristics of the activity, and (3) serve as a quick reference to pertinent published literature on the eruptions and unrest documented in this report.

\footnotetext{
${ }^{1}$ USGS Cascades Volcano Observatory, Vancouver, Washington.

${ }^{2}$ USGS Volcano Hazards Program, Reston, Virginia.
} 


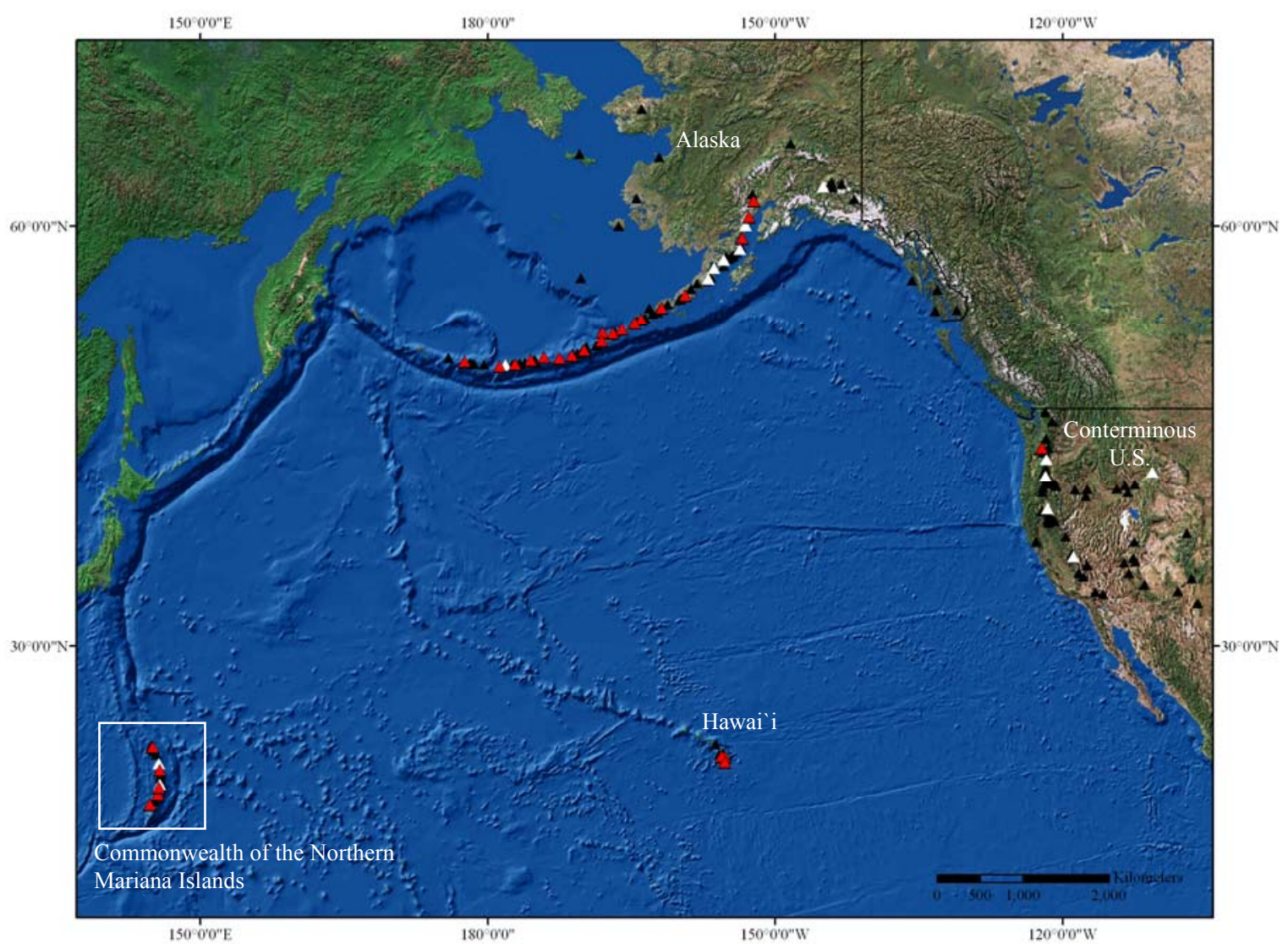

Figure 1. Geographic distribution of volcanic centers in the United States. Volcanoes that have erupted since 1980 are displayed as red triangles, and volcanoes that have produced episodes of unrest without eruption are displayed as white triangles. The remainder of all U.S. volcanic centers are displayed as black triangles.

\section{Methodology}

\section{Eruption Criteria}

Eruption data were acquired from the Smithsonian Institution's Global Volcanism Program (GVP) Web site (www.volcano.si.edu) and activity reports of the five U.S. volcano observatories. Criteria used to define and document eruptive events were adopted from the GVP and are discussed below. We adopted the GVP criteria to maintain consistency with the global catalog of volcanic activity maintained by the GVP.

As defined by the GVP, an eruption is the arrival of solid volcanic products at the Earth's surface. Following this definition, volcanic events such as steam emissions (that do not produce ash), no matter how vigorous, are not counted as eruptions in this report. Arrival of juvenile magma at the surface, however, is also not required; eruptions that eject non-juvenile material are included in the GVP definition of an eruption and are included in this report. The end of an eruption is determined by the conclusion of 
eruptive activity, even though a formal declaration by an observatory may not occur until months later.

The word eruption, in singular form, has had variable definitions applied to it with respect to the duration of volcanic activity. Depending on the observer, an eruption can be defined as a single event that lasts hours to an eruptive episode on a decadal time scale. In this report, with a few exceptions, we have separated volcanic eruptions into independent events if the period of quiet between eruptive events exceeds three months. This standardization, established by the GVP, provides a consistent accounting of recent volcanic eruptions.

Volcanic eruptions listed in this report are confirmed by the USGS or a State, Federal or academic partner of the USGS. Because some volcanoes are remote or lack monitoring stations, especially some in Alaska and the Commonwealth of the Northern Mariana Islands, there are several reports of "suspected" eruptions in the GVP database and in observatory activity logs (Siebert and Simkin, 2002-). The "suspected" reports in the GVP database and observatory activity logs often come from eyewitness accounts of eruptive activity or from ground-based monitoring data that suggest volcanic activity, but were not confirmed visually or on the basis of satellite images by USGS scientists. To provide reliable documentation of volcanic eruptions, any "suspected" events were omitted, and only those eruptions confirmed by the USGS or its partner agencies are included in this report.

\section{Unrest Criterion}

Although eruptions are typically preceded by unrest that may last for days to months, not all unrest culminates in eruption. In this report, we distinguish unrest as unusual non-eruptive activity from precursory unrest that has led to eruption. Owing to the variable character of background activity at individual volcanoes, specifying such activity as unrest in a consistent manner can be problematical. Activity such as steam plumes, thermal anomalies, seismic events, or degassing may be anomalous at one volcano, but typical background activity at another. Moreover, detection and characterization of unrest is often dependent on the historical record of a volcano, as determined by years of direct observation, or data from ground-based monitoring networks, records that are not available at many U.S. volcanoes (Ewert and others, 2005). For the purpose of this report, we selected unrest episodes based on the criterion that a volcano observatory responded in some way to each episode listed in this report. Observatory responses may have included an alert-level notification or information release describing changes in volcanic behavior (Gardner and Guffanti, 2006) or may have consisted of actions, such as the installation of monitoring equipment or additional fieldwork performed by scientists to gather more information about the unrest. Most cases of unrest reported here involved both a formal alert-level notification or information release to the public and field-based investigations by an observatory.

The record of unrest duration is provided by data from visual observations, ground-based monitoring networks, and/or remote-sensing platforms. The end of an episode of unrest usually is determined by the cessation of anomalous activity of unrest (for example, end of earthquake swarm, deformation has stopped, degassing is no longer occurring). In some cases the duration of unrest may be associated or confirmed with an alert-level notification or information release that states the end of the episode of unrest. 
A special case of unrest is the record of nearly continuous (1980 to present) unrest of Yellowstone and Long Valley calderas. Owing to the large size of the underlying magma systems and their complex tectonic settings, Yellowstone and Long Valley calderas exhibit some form of unrest such as earthquakes, ground deformation, and degassing activity, on a frequent, recurring basis. In general, caldera unrest is characterized by extended periods of background unrest that may last for decades (Newhall and Dzurisin, 1988). Such is the case at Yellowstone and Long Valley calderas since the beginning of this report period, and we have designated them as exhibiting continuous unrest.

\section{Documentation}

Publications in the form of journal articles, GVP monthly reports, conference abstracts, and USGS reports constitute the selected references about each eruptive or unrest episode in Part II of this report. The list of references included in this report typically is incomplete for each volcano or each volcanic event. For eruptions or episodes of unrest that have resulted in the publication of a substantial literature, such as

the eruptions of Mount St. Helens or the unrest at Long Valley Caldera, we have included only research publications that provide key information, summarize the event comprehensively, or elicit other published literature. In other cases, such as the eruption of Kiska in 1990, the number of published studies is few. For these events, all known publications were included. The headers indicate in Part II whether the citations are selected or comprehensive.

\section{Eruptions and Unrest}

Because its vast geography encompasses several different tectonic regimes, the United States is home to a spectrum of volcanism that includes explosive stratovolcanoes, effusive shield volcanoes, and restless calderas. The resultant styles of eruption and unrest are as diverse as the volcano types and range in eruptive class from smallmagnitude lava flows to significant pyroclastic eruptions and in signatures of unrest from phreatic explosions to hazardous degassing.

During the past 29 years, 43 volcanoes within the United States have produced 95 eruptions and 32 episodes of unrest (table 1; fig. 2). More than half of the 30 eruptive volcanoes have erupted two or more times. The majority ( 77 percent) of U.S. eruptions has occurred in Alaska. Akutan volcano in Alaska has produced the most eruptions (11) in the past 29 years, followed by Veniaminof (10), Cleveland (9), and Pavlof (8).

Table 1 of this report will be updated as warranted by events and is available online at http://volcanoes.usgs.gov/activity_since_1980/.

The total numbers of eruptions and unrest episodes reported here are minimum values. Unrest or small eruptions of isolated volcanoes with little to no ground-based monitoring may have gone unnoticed. The number of suspected eruptive events $(>20)$ reported by the GVP and observatory activity logs alone suggest that volcanic activity in the United States may be more abundant than what is reported in table 1. 
An increase in the number of reported episodes of volcanic unrest during the past 29 years began shortly after AVO was established in 1988 and became a consistent source of activity reporting (fig. 3). Since 1996, AVO has installed seismic networks on more than two dozen Aleutian volcanoes, thus greatly improving its ability to detect signs of unrest (Brantley and others, 2004). In addition to expanded ground-based monitoring, AVO began routine and systematic use of remote sensing to monitor Alaskan volcanoes and to detect activity that otherwise might have gone unnoticed in the absence of groundbased sensor networks.

Satellite-based methods for volcano surveillance have improved substantially in the past two decades. A technique useful for detecting unrest is Interferometric Synthetic Aperture Radar (InSAR), which measures surface deformation at volcanic centers ( $\mathrm{Lu}$ and others, 1997). A specific example of the success of InSAR was its ability to detect aseismic uplift that began in 1998 west of South Sister volcano (Wicks and others, 2002), activity that likely would not have been recognized before the application of InSAR (fig. 4). Due to the InSAR results, additional instrumentation was installed, and the ongoing deformation is also monitored by yearly field campaigns.

Table 1. Description and chronology of volcanic eruptions and unrest in the United States from 1980 through 2008.

\begin{tabular}{|c|c|c|c|}
\hline $\begin{array}{l}\text { GVP }^{\text {a }} \\
\text { VOLCANO } \\
\text { NUMBER }\end{array}$ & VOLCANO & $\begin{array}{l}\text { ERUPTION DATES } \\
\text { (MM/DD/YYYY) AND VEI } \\
\text { VEI in parenthesis }\end{array}$ & $\begin{array}{l}\text { UNREST EPISODE: } \\
\text { MM/DD/YYYY }\end{array}$ \\
\hline \multicolumn{4}{|l|}{ Hawai i } \\
\hline $1302-00-$ & Lo ihi Seamount & $02 / 25 / 1996-08 / 09 / 1996^{\mathrm{c}}(0)$ & \\
\hline $1302-01-$ & Kîlauea & $\begin{array}{l}03 / 11 / 1980-03 / 11 / 1980(0) \\
04 / 30 / 1982-05 / 01 / 1982(0) \\
09 / 25 / 1982-09 / 26 / 1982(0) \\
01 / 03 / 1983 \text {-present (1) }\end{array}$ & \\
\hline $1302-02=$ & Mauna Loa & 03/25/1984-04/15/1984 (0) & $\begin{array}{l}\text { Inflation and deep seismicity: } \\
\text { 04/24/2002-present }\end{array}$ \\
\hline \multicolumn{4}{|c|}{ Conterminous U.S. } \\
\hline $1201-05-$ & $\begin{array}{l}\text { Mount St. Helens, } \\
\text { Washington }\end{array}$ & $\begin{array}{l}03 / 27 / 1980-10 / 26 / 1986(5) \\
12 / 07 / 1989-01 / 06 / 1990(2) \\
11 / 05 / 1990-02 / 14 / 1991\left(3^{e}\right) \\
10 / 01 / 2004-01 / ? ? / 2008(2)\end{array}$ & $\begin{array}{l}\text { Elevated seismicity: } 01 / 01 / 1995- \\
\text { 10/??/1995 } \\
\text { Elevated seismicity and } \mathrm{CO}_{2} \\
\text { detection: } 05 / ? ? / 1998-07 / ? ? / 1998\end{array}$ \\
\hline
\end{tabular}




\begin{tabular}{|c|c|c|c|}
\hline $\begin{array}{l}\text { GVP }^{\mathrm{a}} \\
\text { VOLCANO } \\
\text { NUMBER }\end{array}$ & VOLCANO & $\begin{array}{l}\text { ERUPTION DATES } \\
\text { (MM/DD/YYYY) AND VEI } \\
\text { VEI in parenthesis }\end{array}$ & $\begin{array}{l}\text { UNREST EPISODE: } \\
\text { MM/DD/YYYY }\end{array}$ \\
\hline $1202-01-$ & $\begin{array}{l}\text { Mount Hood, } \\
\text { Oregon }\end{array}$ & & $\begin{array}{l}\text { Earthquake swarm: 07/06/1980- } \\
\text { 08/05/1980 } \\
\text { Earthquake swarm: 01/11/1999- } \\
01 / 14 / 1999 \\
\text { Earthquake swarm: 01/10/2001- } \\
01 / 19 / 2001 \\
\text { Earthquake swarm: 06/29/2002- } \\
06 / 29 / 2002\end{array}$ \\
\hline $1202-08-$ & $\begin{array}{l}\text { South Sister, } \\
\text { Oregon }\end{array}$ & & $\begin{array}{l}\text { Uplift began } 1998^{*} \text { - continues at } \\
\text { present (earthquake swarm: } \\
03 / 23 / 2004-03 / 25 / 2004)\end{array}$ \\
\hline $1203-02-$ & $\begin{array}{l}\text { Medicine Lake, } \\
\text { California }\end{array}$ & & $\begin{array}{l}\text { Earthquake swarm: 09/29/1988- } \\
11 / 15 / 1988\end{array}$ \\
\hline 120314-A & $\begin{array}{l}\text { Long Valley } \\
\text { Caldera, California }\end{array}$ & & $\begin{array}{l}\text { Recurrent earthquake swarms, } \\
\text { changes in thermal springs and gas } \\
\text { emissions, and uplift since } \\
05 / 25 / 1980 \text { and } \mathrm{CO}_{2} \text { emission from } \\
\text { ground since } 05 / 01 / 1989\end{array}$ \\
\hline $1205-01-$ & $\begin{array}{l}\text { Yellowstone } \\
\text { Caldera, Wyoming }\end{array}$ & & $\begin{array}{l}\text { Recurrent earthquake swarms and } \\
\text { ground deformation (uplift and } \\
\text { subsidence), changes in } \\
\text { hydrothermal features: 1980- } \\
\text { present }\end{array}$ \\
\hline \multicolumn{4}{|l|}{ Alaska } \\
\hline 1101-02- & Kiska & $06 / 01 / 1990-06 / 01 / 1990(2)$ & \\
\hline 1101-06- & $\begin{array}{l}\text { Sugarloaf Peak } \\
\text { (Semisopochnoi) }\end{array}$ & 04/13/1987-05/26/1987 (2 $\left.2^{\mathrm{e}}\right)$ & \\
\hline 1101-07- & Gareloi & $\begin{array}{l}08 / 07 / 1980-09 / 17 / 1980\left(3^{\mathrm{e}}\right) \\
01 / 15 / 1982-01 / 15 / 1982(3) \\
09 / 04 / 1987-?\left(1^{\mathrm{e}}\right) \\
08 / 17 / 1989-?(1)\end{array}$ & \\
\hline 1101-08- & Tanaga & & $\begin{array}{l}\text { Earthquake swarm: } 10 / 01 / 2005- \\
11 / 25 / 2005\end{array}$ \\
\hline 1101-11- & Kanaga & 01/05/1994-06/23/1995 (2) & \\
\hline $1101-13-$ & Kasatochi & $08 / 07 / 2008-08 / 08 / 2008\left(4^{\mathrm{d}}\right)$ & \\
\hline 1101-16- & Korovin (Atka) & $\begin{array}{l}03 / 04 / 1987-03 / 18 / 1987(2) \\
06 / 30 / 1998-06 / 30 / 1998^{*}(3) \\
11 / 25 / 2006-03 / 03 / 2007(1)\end{array}$ & $\begin{array}{l}\text { Earthquake swarms, steam, and ash } \\
\text { plumes: } 02 / 23 / 2005-05 / 07 / 2005\end{array}$ \\
\hline 1101-18- & Seguam & $\begin{array}{l}12 / 27 / 1992-12 / 30 / 1992(2) \\
05 / 28 / 1993-08 / 19 / 1993 *(2)\end{array}$ & \\
\hline 1101-19- & Amukta & $\begin{array}{l}09 / 04 / 1987-09 / 04 / 1987 *(1) \\
07 / ? ? / 1996-09 / ? ? / 1996(1)\end{array}$ & \\
\hline
\end{tabular}




\begin{tabular}{|c|c|c|c|}
\hline $\begin{array}{l}\text { GVP }^{\mathrm{a}} \\
\text { VOLCANO } \\
\text { NUMBER }\end{array}$ & VOLCANO & $\begin{array}{l}\text { ERUPTION DATES } \\
(\mathrm{MM} / \mathrm{DD} / \mathrm{YYYY}) \text { AND VEI } \\
\text { VEI in parenthesis }\end{array}$ & $\begin{array}{l}\text { UNREST EPISODE: } \\
\text { MM/DD/YYYY }\end{array}$ \\
\hline $1101-24-$ & Cleveland & $\begin{array}{l}07 / 12 / 1984-07 / 12 / 1984(1) \\
04 / 28 / 1986-05 / 27 / 1986(2) \\
06 / 19 / 1987-08 / 28 / 1987(3) \\
05 / 25 / 1994-05 / 25 / 1994(3) \\
05 / 05 / 1997-05 / 05 / 1997(2) \\
02 / 02 / 2001-04 / 15 / 2001(3) \\
04 / 27 / 2005-09 / 27 / 2005(2) \\
02 / 06 / 2006-10 / 28 / 2006(3) \\
06 / ? ? / 2007-09 / 04 / 2008^{*}(2) \\
\end{array}$ & \\
\hline 1101-29- & Okmok & $\begin{array}{l}03 / 24 / 1981-03 / 24 / 1981\left(3^{\mathrm{e}}\right) \\
07 / 08 / 1983-07 / 08 / 1983(2) \\
11 / 18 / 1986-02 / 26 / 1988^{*}(2) \\
02 / 13 / 1997-05 / 23 / 1997(3) \\
07 / 12 / 2008-08 / ? ? / 2008\left(4^{\mathrm{d}}\right) \\
\end{array}$ & $\begin{array}{l}\text { Earthquake swarm: 05/11/2001- } \\
05 / 15 / 2001\end{array}$ \\
\hline $1101-30-$ & Bogoslof & $07 / 06 / 1992-07 / 24 / 1992(3)$ & \\
\hline $1101-31-$ & Makushin & $\begin{array}{l}05 / ? ? / 1980-?(1) \\
01 / 30 / 1995-01 / 30 / 1995(1)\end{array}$ & $\begin{array}{l}\text { Elevated seismicity: 07/??/2000- } \\
\text { 06/??/2001 }\end{array}$ \\
\hline 1101-32- & Akutan & $\begin{array}{l}07 / 08 / 1980-07 / 08 / 1980(2) \\
10 / 07 / 1982-05 / ? ? / 1983(2) \\
02 / 03 / 1986-06 / 14 / 1986(2) \\
01 / 31 / 1987-06 / 24 / 1987(2) \\
03 / 26 / 1988-07 / 20 / 1988(2) \\
02 / 27 / 1989-03 / 31 / 1989(2) \\
01 / 22 / 1990-01 / 22 / 1990^{*}(2) \\
09 / 06 / 1990-10 / 01 / 1990(2) \\
09 / 15 / 1991-11 / 28 / 1991^{*}(2) \\
03 / 08 / 1992-05 / 31 / 1992(2) \\
12 / 18 / 1992-?(1) \\
\end{array}$ & $\begin{array}{l}\text { Intense earthquake swarm and } \\
\text { intrusion with ground cracks: } \\
03 / 10 / 1996-03 / 18 / 1996\end{array}$ \\
\hline 1101-34- & Westdahl & 11/29/1991-01/15/1992*(3) & \\
\hline 1101-36- & Shishaldin & $\begin{array}{l}03 / 19 / 1986-03 / ? ? / 1987(2) \\
12 / 23 / 1995-05 / 16 / 1996^{*}(3) \\
06 / 02 / 1997-06 / 02 / 1997(1) \\
02 / 09 / 1999-05 / 28 / 1999(3) \\
02 / 17 / 2004-05 / 17 / 2004(2)\end{array}$ & $\begin{array}{l}\text { Small phreatic explosions: } \\
\text { 09/25/1999-02/04/2000 } \\
\text { Increased seismicity: } \\
\text { 05/15/2002-08/16/2002* } \\
\text { Earthquakes, tremor, and thermal } \\
\text { anomalies: } 02 / 22 / 2005-02 / 22 / 2005 \\
\end{array}$ \\
\hline $1102-011$ & Dutton & & $\begin{array}{l}\text { Earthquake swarm: 07/10/1988- } \\
08 / 08 / 1988\end{array}$ \\
\hline 1102-03- & Pavlof & $\begin{array}{l}11 / 08 / 1980-11 / 13 / 1980(3) \\
09 / 25 / 1981-09 / 27 / 1981(3) \\
07 / 11 / 1983-07 / 18 / 1983\left(2^{\mathrm{e}}\right) \\
11 / 14 / 1983-12 / 18 / 1983(3) \\
04 / 16 / 1986-08 / 13 / 1988(3) \\
01 / 05 / 1990-03 / 05 / 1990(2) \\
09 / 16 / 1996-01 / 03 / 1997(2) \\
08 / 15 / 2007-09 / 13 / 2007(2)\end{array}$ & \\
\hline
\end{tabular}




\begin{tabular}{|c|c|c|c|}
\hline $\begin{array}{l}\text { GVP }^{\mathrm{a}} \\
\text { VOLCANO } \\
\text { NUMBER }\end{array}$ & VOLCANO & $\begin{array}{l}\text { ERUPTION DATES } \\
\text { (MM/DD/YYYY) AND VEI } \\
\text { VEI in parenthesis }\end{array}$ & $\begin{array}{l}\text { UNREST EPISODE: } \\
\text { MM/DD/YYYY }\end{array}$ \\
\hline 1102-07- & Veniaminof & $\begin{array}{l}06 / 02 / 1983-04 / 17 / 1984(3) \\
11 / 29 / 1984-12 / 09 / 1984(2) \\
07 / 30 / 1993-08 / 28 / 1994^{*}(2) \\
04 / 17 / 1995-11 / 30 / 1995(1) \\
09 / 28 / 2002-03 / 23 / 2003(1) \\
02 / 19 / 2004-09 / ? ? / 2004(2) \\
01 / 04 / 2005-02 / 25 / 2005^{*}(2) \\
09 / 07 / 2005-11 / 04 / 2005(1) \\
03 / 03 / 2006-09 / 07 / 2006(1) \\
02 / 22 / 2008-05 / 03 / 2008^{*}\left(2^{\mathrm{d}}\right) \\
\end{array}$ & \\
\hline $1102-11-$ & Chiginagak & & $\begin{array}{l}\text { Fumarolic activity and steam } \\
\text { plumes: } 10 / 22 / 1997-08 / 21 / 1998 \\
\text { Changes in hydrothermal features, } \\
\text { gas emissions, and a lahar } \\
\text { occurred: } 11 / ? ? / 2004-07 / ? ? / 2005^{*}\end{array}$ \\
\hline $1102-14-$ & Martin & & $\begin{array}{l}\text { Strong seismic swarm: } \\
01 / 08 / 2006-01 / 22 / 2006\end{array}$ \\
\hline $1102-26-$ & Fourpeaked & $09 / 17 / 2006-09 / 17 / 2006(2)$ & \\
\hline $\begin{array}{l}1102131 / \\
1102-13-\end{array}$ & $\begin{array}{l}\text { Ukinrek } \\
\text { Maars/Ugashik- } \\
\text { Peulik }\end{array}$ & & $\begin{array}{l}\text { Earthquake swarm: 05/08/1998- } \\
06 / 15 / 1998\end{array}$ \\
\hline 1103-01- & Augustine & $\begin{array}{l}03 / 27 / 1986-09 / 10 / 1986(4) \\
12 / ? ? / 2005-03 / 31 / 2006(3)\end{array}$ & \\
\hline 1103-02- & Iliamna & & $\begin{array}{l}\text { Earthquake swarm and elevated } \\
\text { gas emission: 05/10/1996- } \\
02 / ? ? / 1997\end{array}$ \\
\hline 1103-03- & Redoubt & 12/14/1989-06/??/1990 (3) & $\begin{array}{l}\text { Elevated gas emissions and } \\
\text { increase in heat output: } \\
07 / ? ? / 2008 \text {-present }\end{array}$ \\
\hline 1103-04- & Spurr & 06/27/1992-09/17/1992 (4) & $\begin{array}{l}\text { Elevated seismicity, melt pit at } \\
\text { summit, and increase in } \mathrm{CO}_{2} \text { and } \\
\mathrm{SO}_{2} \text { emissions: } 07 / ? ? / 2004- \\
02 / ? ? / 2006\end{array}$ \\
\hline \multicolumn{4}{|c|}{ Commonwealth of the Northern Mariana Islands } \\
\hline $0804-16=$ & Agrigan & & $\begin{array}{l}\text { Increased fumarolic activity: } \\
08 / 01 / 1990-10 / 06 / 1990\end{array}$ \\
\hline $0804-17=$ & Pagan & $\begin{array}{l}05 / 15 / 1981-05 / 01 / 1985^{*}(4) \\
09 / 04 / 1987-09 / 04 / 1987(1) \\
08 / 24 / 1988-10 / 12 / 1988(2) \\
04 / 13 / 1992-04 / 13 / 1992(1) \\
01 / 15 / 1993 *-11 / ? ? / 1993(2) \\
12 / 04 / 2006-12 / 08 / 2006(1) \\
\end{array}$ & \\
\hline $0804-20=$ & Anatahan & $\begin{array}{l}05 / 10 / 2003-07 / 12 / 2003 *(3) \\
04 / 12 / 2004-09 / 03 / 2005 *(3) \\
03 / 20 / 2006-06 / 26 / 2006 *(2) \\
11 / 27 / 2007-02 / ? ? / 2008^{*}(1)\end{array}$ & $\begin{array}{l}\text { Earthquake swarm, crater lake } \\
\text { refills: 03/30/1990-10/31/1990 } \\
\text { Earthquake swarm: 05/29/1993- } \\
09 / ? ? / 1993 \\
\text { Elevated seismicity: 02/??/2008- } \\
\text { 10/??/2008 }\end{array}$ \\
\hline 0804-141 & Ahyi & $04 / 24 / 2001-04 / 25 / 2001^{\mathrm{c}}(0)$ & \\
\hline 0804-192 & Sarigan & & $\begin{array}{l}\text { Earthquake swarm: 08/09/2005- } \\
08 / 19 / 2005\end{array}$ \\
\hline
\end{tabular}




\begin{tabular}{|l|l|l|l|}
\hline $\begin{array}{l}\text { GVP } \\
\text { VOLCANO } \\
\text { NUMBER }\end{array}$ & VOLCANO & $\begin{array}{l}\text { ERUPTION DATES } \\
\text { (MM/DD/YYYY) AND VEI } \\
\text { VEI in parenthesis }\end{array}$ & $\begin{array}{l}\text { UNREST EPISODE: } \\
\text { MM/DD/YYYY }\end{array}$ \\
\hline $0804-202$ & Ruby & $10 / 11 / 1995-10 / 25 / 1995^{\mathrm{c}}(0)$ & \\
\hline $0804-211$ & NW Rota-1 & $2003^{*}-02 / ? ? / 2008^{* c}(0)$ & \\
\hline
\end{tabular}

${ }^{a}$ Global Volcanism Program.

${ }^{\mathrm{b}}$ Volcanic Explosivity Index (eruption magnitude).

${ }^{\mathrm{c}}$ Submarine eruption.

${ }^{\mathrm{d}}$ Provisional VEI assignment based on eruption column height. A formal VEI has not been assigned owing to how recently the event occurred.

${ }^{\mathrm{e}}$ Inferred VEI assignment due to difficulty of designation or based on anecdotal evidence

* and ? represent approximate or unknown dates, respectively. 


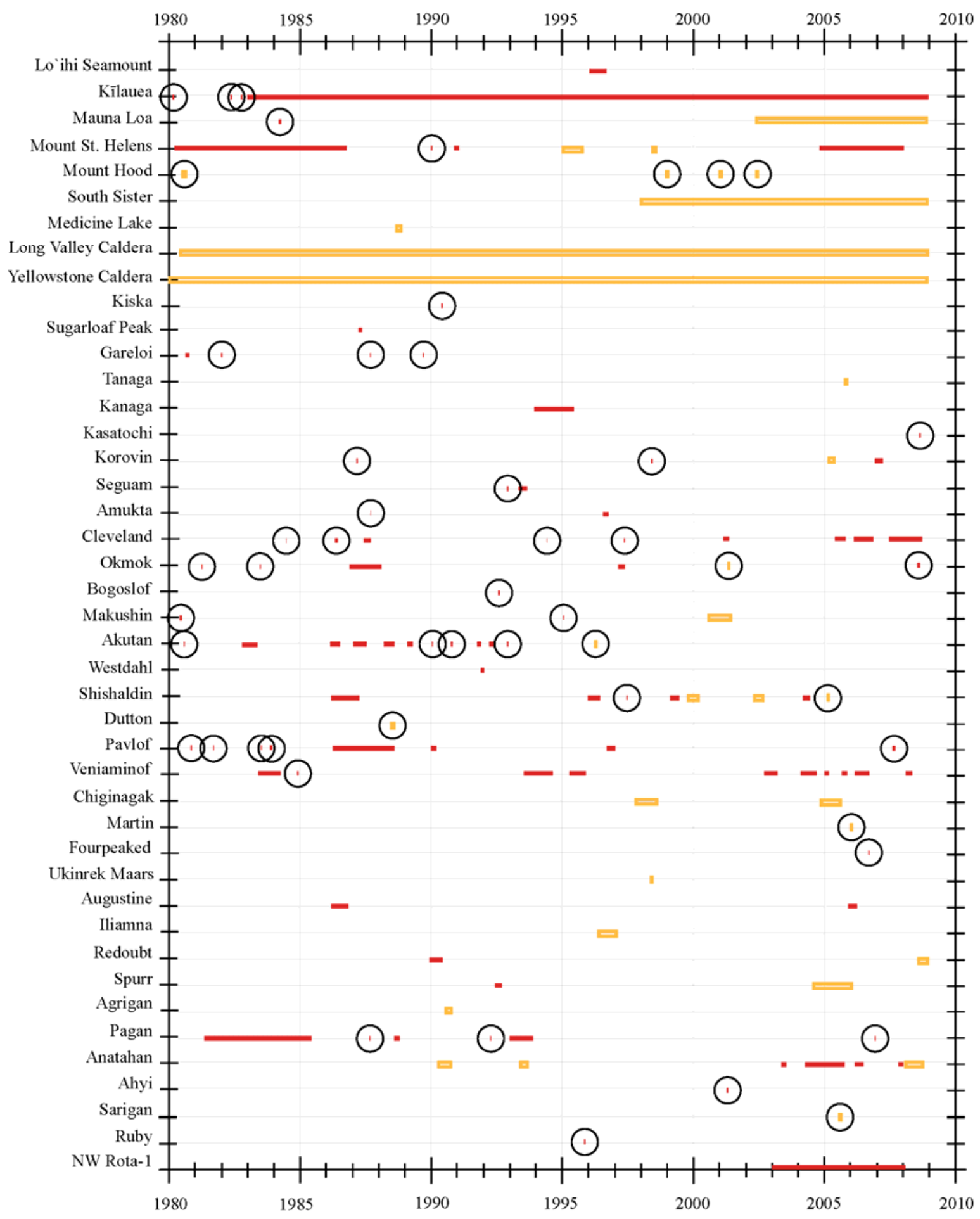

Figure 2. Time line of eruptions (solid red lines) and unrest (orange lines) that occurred from 1980 to 2008 at U.S. volcanoes. Length of lines corresponds to the duration of each volcanic event. Black circles highlight events with a duration equal to or less than about 1 month. 


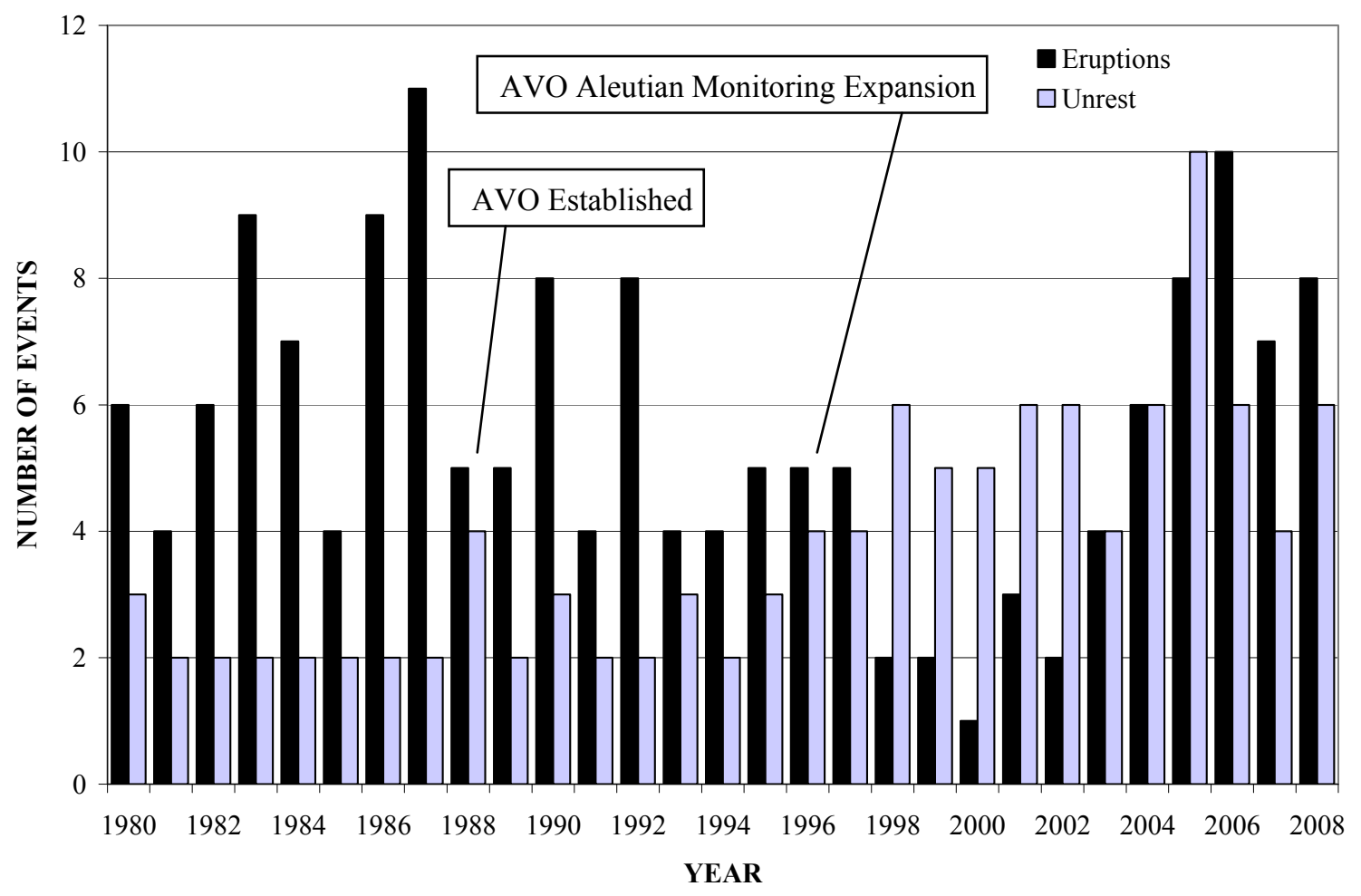

Figure 3. Number of volcanic eruptions and episodes of selected unrest that occurred during the course of each year, from 1980 to 2008. The number plotted is a summation of those events that are either ongoing across years or new. The establishment of AVO in 1988 and the beginning of the AVO monitoring expansion in 1996 provided a more reliable report of volcanic unrest in Alaska. The minimum number of unrest events is always maintained at two due to the continuous unrest of Yellowstone and Long Valley calderas (1980 to present).

\section{Frequency and Magnitude}

Including continuing volcanic events that span a calendar year, within the reporting period there have been, on average, five volcanic eruptions and five episodes of unrest occurring each year in the United States. With the exception of 1985 and 2000, at least one eruption has started in each year of the past nearly three decades (fig. 2). Counting year-spanning eruptions and episodes of unrest, every year between 1980 and 2008 included a volcanic event, including 1985 and 2000 when six and nine events, respectively, occurred within or throughout those years (fig. 3). The maximum number of events to occur during a 12-month period was in 2005, when a total of 18 events (10 episodes of unrest and 8 eruptions) were reported. Note that this is not counting concurrent events, rather that 18 events occurred at some point within this 12-month timeframe by either continuing into 2005 from a previous year or beginning in 2005 . 


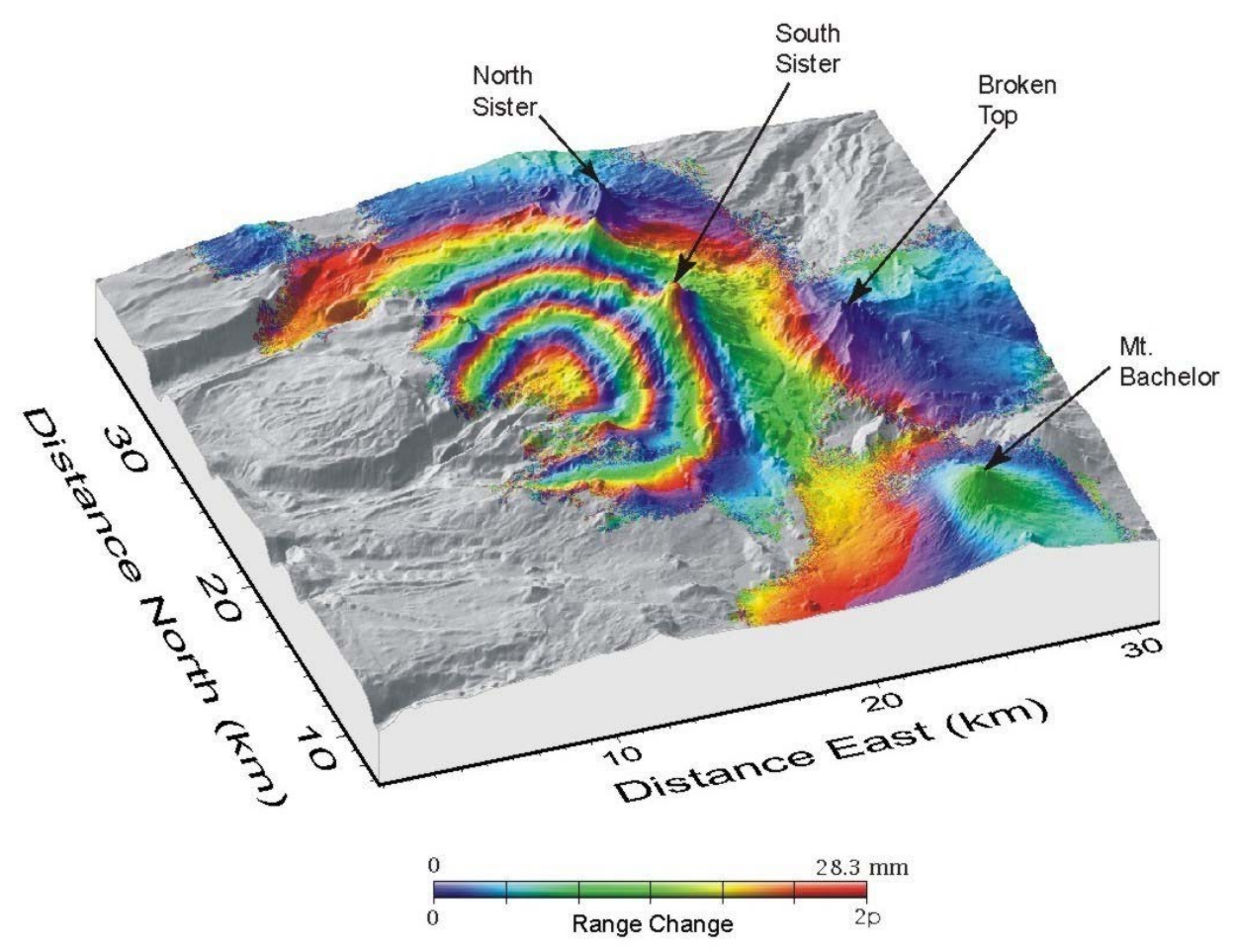

Figure 4. Active surface deformation first detected by InSAR in 2001 west of South Sister volcano in central Oregon. The above interferogram was constructed from data spanning 1996 to 2000 and draped over a $30 \mathrm{~m}$ digital elevation model (Wicks and others, 2002). Each range change (full color cycle) represents $2.8 \mathrm{~cm}$ of uplift. The maximum uplift (not pictured above) that occurred at South Sister between 1998 and 2000 was $\sim 10 \mathrm{~cm}$ (Wicks and others, 2002). Since 2001, the USGS has deployed other ground-based monitoring instrumentation to track the ongoing deformation at South Sister.

The volcanic explosivity index (VEI; Newhall and Self, 1982) describes a relative measure of the size and energy of a volcanic eruption on a scale of 0-8 (low to high). Historical records of worldwide VEI display a log-linear relation between frequency and size; that is, many small eruptions and few large eruptions (Simkin and Siebert, 1999). As reported in table 1 and as seen in fig. 5, the 68 recorded U.S. eruptions with VEI $>1$ also follow a log-linear trend. The largest eruption to take place in the past 29 years in the U.S. was the May 18, 1980, eruption of Mount St. Helens (VEI 5). Pagan (19811985), Spurr (1992), Augustine (1986), and Kasatochi (2008) all produced VEI 4 eruptions. 


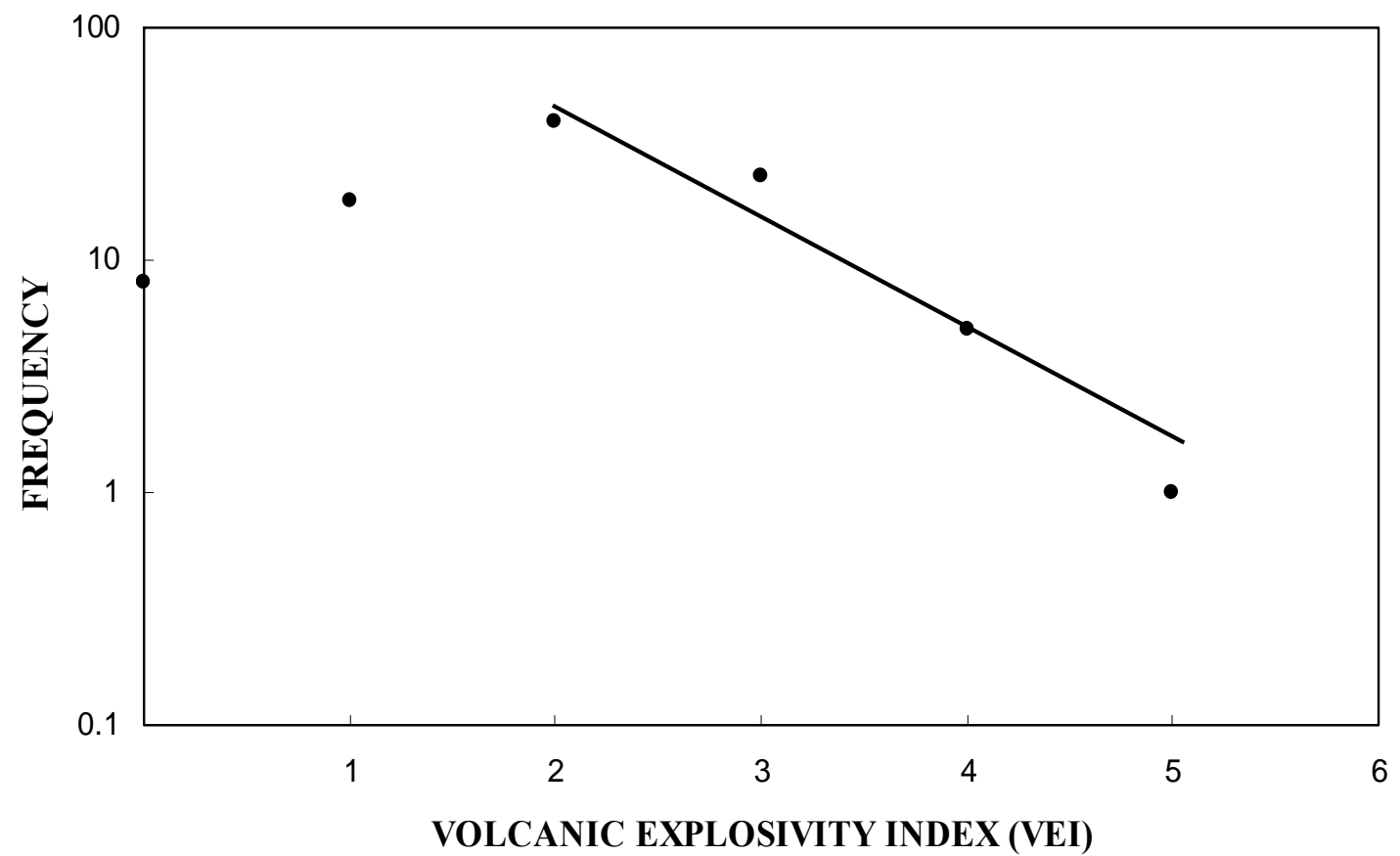

Figure 5. Frequency and magnitude (VEI) of 95 eruptions from 1980 to 2008 at U.S. volcanoes. The best-fit line is an exponential regression determined from 68 eruptions with assigned VEI $\geq 2$. Eruptions of low magnitude (VEI 1 and 0 ) are not included in the best-fit line because they are difficult to distinguish from available field criteria, resulting in misrepresentation of the frequency of small events. For a list of VEI assigned to individual eruptions see table 1.

\section{Durations}

The durations of eruptions range widely at U.S. volcanoes (fig. 6) from time scales of hours to decades. Reporting a simple average duration of volcanic events greatly exaggerates the typical durations. Median durations provide better insight into the recent activity of U.S. volcanoes. The median duration of volcanic eruptions reported here is 1.6 months, a value consistent with global data reported by Simkin and Siebert (1999). We do not report a median duration of unrest because our record is a select subset of unrest events and, therefore, does not fully represent a comprehensive dataset. 


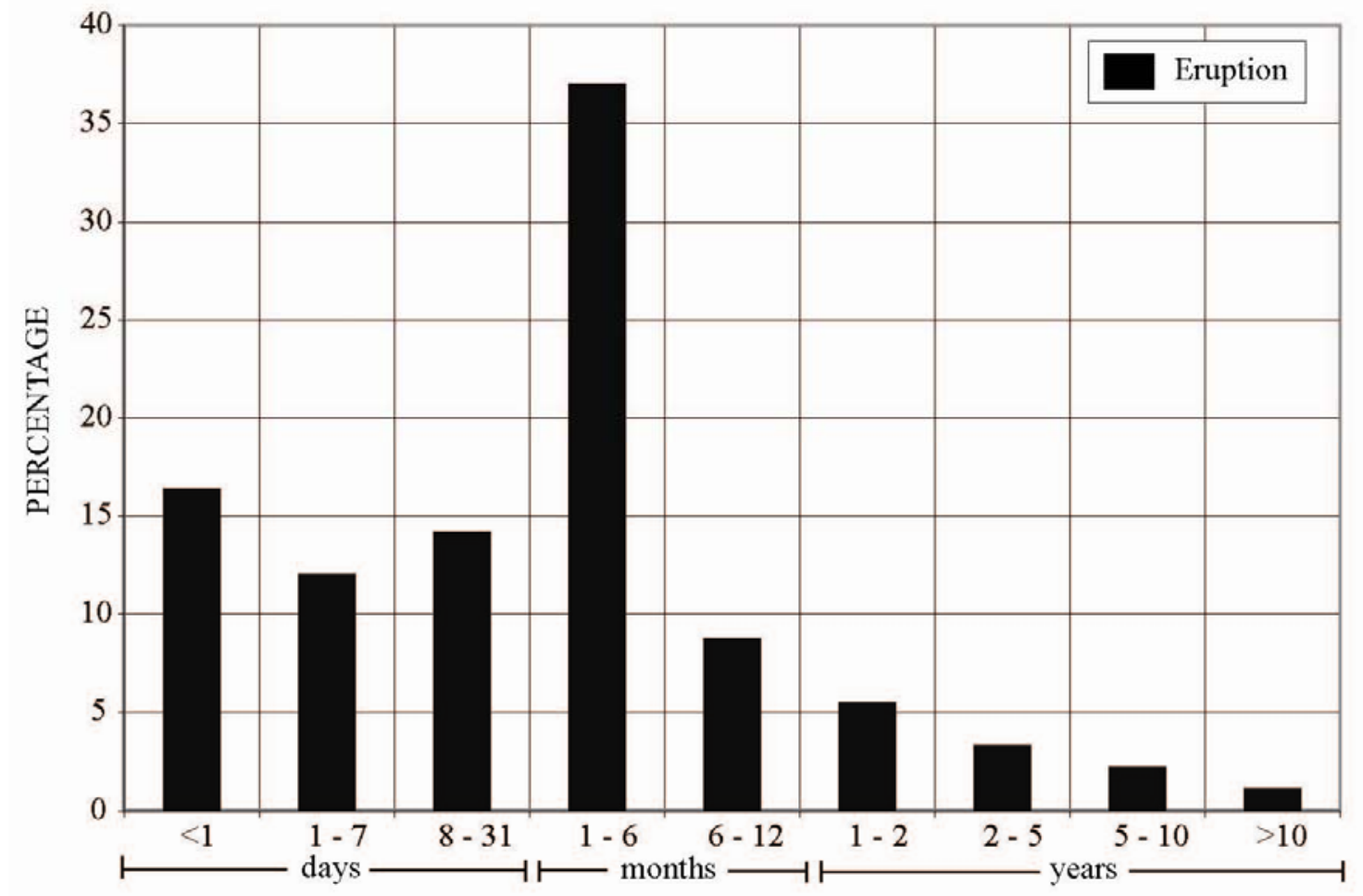

Figure 6. Frequency histogram of duration of eruptions. The vertical axis is the percentage of the totals of 92 eruptions (excluding three events absent of a stop date). The horizontal axis is time separated into days, months, and years. Median duration of eruptions in the U.S., as reported from 1980 to 2008 , is 1.6 months.

\section{Conclusion}

The nearly three decades of events listed in this report provide a snapshot of volcanic activity in the United States. However, three-quarters of the potentially active volcanoes in the U.S., that are not discussed here, also pose threats to infrastructure, economic activity, and people on the ground and in the air (Ewert and others, 2005; Ewert, 2007). Moreover, recurrence intervals between large eruptions typically are longer than the scope of this report's time line (Simkin and Siebert, 1999); thus, the largest, most hazardous eruptions are under represented here.

The United States is a volcanically vigorous country, and it experiences frequent volcanic unrest and eruptive activity each year. During the past 29 years, U.S. volcanoes have produced large explosive eruptions (five with VEI $\geq 4$ ), as well as numerous smaller ones, long-lived eruptions (notably Kīlauea volcano), and diverse signatures of unrest. The great range of volcanic activity and attendant hazards in the United States warrants a robust program of monitoring and research to understand volcanic processes and the attendant hazards. 


\section{References}

Brantley, S.R., McGimsey, R.G., and Neal, C.A., 2004, The Alaska Volcano Observatory-Expanding monitoring of volcanoes yields results: U.S. Geological Survey Fact Sheet 2004-3084, 2 p.

Ewert, J., 2007, System for ranking relative threats of U.S. volcanoes: Natural Hazards Review, v. 8, no. 4, p. 112-124.

Ewert, J., Guffanti, M., and Murray, T., 2005, An assessment of volcanic threat and monitoring capabilities in the United States-Framework for a National Volcano Early Warning System (NVEWS): U.S. Geological Survey Open-File Report 2005-1164, 36 p.

Gardner, C.A., and Guffanti, M.C., 2006, U.S. Geological Survey's Alert Notification System for volcanic activity: U.S. Geological Survey Fact Sheet 2006-3139, 4 p.

Lu, Z., Fatland, R., Wyss, M., Li, S., Eichelberger, J., Dean, K., and Freymueller, J., 1997, Deformation of New Trident volcano measured by ERS-1 SAR interferometry, Katmai National Park, Alaska: Geophysical Research Letters, v. 24, p. 695-698.

Newhall, C.G., and Dzurisin, D., 1988, Historical unrest at large calderas of the world: U.S. Geological Survey Bulletin 1855, 1108 p.

Newhall, C.G., and Self, S., 1982, The volcanic explosivity index (VEI)—An estimate of explosive magnitude for historical volcanism: Journal of Geophysical Research, v. 87, p. 1231-1238.

Siebert, L., and Simkin, T., 2002-, Volcanoes of the world-An illustrated catalog of Holocene volcanoes and their eruptions: Smithsonian Institution, Global Volcanism Program Digital Information Series, GVP-5, [available at http://www.volcano.si.edu/world/, last accessed December 2008].

Simkin, T., and Siebert, L., 1999, Earth's volcanoes and eruptions-An overview, in Sigurdsson, H., Houghton, B.F., McNutt, S.R., Rymer, H., and Stix, J., eds., Encyclopedia of volcanoes: London, Academic Press, p. 249-261.

Wicks, C.W., Jr., Dzurisin, D., Ingebritsen, S., Thatcher, W., Lu, Z., and Iverson, J., 2002, Magmatic activity beneath the quiescent Three Sisters volcanic center, central Oregon Cascade Range, USA: Geophysical Research Letters, v. 29, no. 7, doi:10.1029/2001GL014205. 


\title{
Part II
}

\section{References of Volcanic Eruptions and Unrest, 1980-2008}

\author{
Lo`ihi Seamount \\ 1302-00-
}

Selected References

1996 Submarine Eruption:

Caplan-Auerbach, J., and Duennebier, F., 2001a, Seismicity and velocity structure of Lo ihi seamount from the 1996 earthquake swarm: Bulletin of the Seismological Society of America, v. 91, no. 2, p. 178-190.

Caplan-Auerbach, J., and Duennebier, F., 2001b, Seismic and acoustic signals detected at Lo ihi seamount by the Hawai i Undersea Geo-Observatory: Geochemistry, Geophysics, Geosystems, v. 2, no. 5, doi:10.1029/2000GC000113, 17 p.

Clague, D.A., Batiza, R., Head, J.W., III, and Davis, A.S., 2003, Pyroclastic and hydroclastic deposits on Lo ihi Seamount, Hawai 'i, in White, J.D.L., Smellie, J.L., and Clague, D.A., eds., Explosive subaqueous volcanism: American Geophysical Union, Geophysical Monograph 140, p. 73-95.

Clague, D.A., Davis, A.S., Bischoff, J.L., Dixon, J.E., and Geyer, R., 2000, Lava bubblewall fragments formed by submarine hydrovolcanic explosions on Lo 'ihi Seamount and Kîlauea Volcano: Bulletin of Volcanology, v. 61, no. 7, p. 437449.

Davis, A.S., and Clague, D.A., 1998, Changes in the hydrothermal system at Lo ihi Seamount after the formation of Pele's Pit in 1996: Geology, v. 26, no. 5, p. 399402.

Davis, A.S., Clague, D.A., Zierenberg, R.A., Wheat, C.G., and Cousens, B.L., 2003, Sulfide formation related to changes in the hydrothermal system on Lo 'ihi Seamount, Hawai 'i, following the seismic event in 1996: Canadian Mineralogist, v. 41, p. 457-472.

Garcia, M., Rubin, K.H., Norman, M.D., Rhodes, J.M., Graham, D.W., Muenow, D., and Spencer, K., 1998, Petrology and geochronology of basalt breccia from the 1996 earthquake swarm of Lo 'ihi Seamount, Hawai i-Magmatic history of its 1996 eruption: Bulletin of Volcanology, v. 59, no. 8, p. 577-592. 
The 1996 Lo 'ihi Science Team, 1997, Researchers rapidly respond to submarine activity at Lo ihi volcano, Hawai'i: Eos, Transactions, American Geophysical Union, v. 78, no. 22, p. 229.

\title{
Kīlauea
}

\author{
1302-01-
}

Selected References

1982 Eruptions

Helz, R.T., Banks, N.G., Heliker, C., Neal, C.A., and Wolfe, E.W., 1995, Comparative geothermometry of recent Hawaiian eruptions: Journal of Geophysical Research, v. 100 , no. B9, p. 17637-17657.

Karpin, T.L., and Thurber, C.H., 1987, The relationship between earthquake swarms and magma transport: Kīlauea volcano, Hawai i: Pure and Applied Geophysics, v. 125 , no. 6, p. 971-991.

\section{Selected References}

\section{3 - Present Eruption}

Garcia, M.O., Pietruszka, A.J., Rhodes, J.M., and Swanson, K., 2000, Magmatic processes during the prolonged Pu 'u ' $\bar{O}$ 'ō eruption of Kīlauea volcano, Hawai' i: Journal of Petrology, v. 41, no. 7, p. 967-990.

Garcia, M.O., Rhodes, J.M., Wolfe, E.W., Ulrich, G.E., and Ho, R.A., 1992, Petrology of lavas from episodes 2-47 of the Pu 'u 'Ō 'o eruption of Kīlauea Volcano, Hawai ${ }^{-}$-Evaluation of magmatic processes: Bulletin of Volcanology, v. 55, p. 116.

Heliker, C., Mangan, M.T., Mattox, T.N., and Kauahikaua, J.P., 1998, Pu ’u 'Ō `ō Kūpaianaha eruption of Kīlauea, November 1991-February 1994; field data and flow maps: U.S. Geological Survey Open-File Report 98-103, 10 p.

Heliker, C., Swanson, D.A., and Takahashi, T.J., eds., 2003, The Pu 'u 'Ō `ō -Kūpaianaha eruption of Kīlauea Volcano, Hawai ${ }^{-}$- - The first twenty years: U.S. Geological Survey Professional Paper 1676, 206 p.

Heliker, C., Ulrich, G.E., Margriter, S.C., and Hoffmann, J.P., 2001, Maps showing the development of the Pu'u 'ō 'o -Kūpaianaha Flow Field, June 1984-February 1987, Kīlauea Volcano, Hawai' i: U.S. Geological Survey Geologic Investigations Series, Map I-2685, 4 sheets, scale 1:50000.

Mangan, M.T., Heliker, C.C., Mattox, T.N., Kauahikaua, J.P., and Helz, R.T., 1995, Episode 49 of the Pu'u 'Ō 'ō -Kūpaianaha eruption of Kĩlauea volcanoBreakdown of a steady-state eruptive era: Bulletin of Volcanology, v. 57, p. 127135. 
Takahashi, T.J., Heliker, C.C., and Diggles, M.F., 2003, Selected images of the Pu 'u 'Ō 'ō -Kūpaianaha eruption, 1983-1997: U.S. Geological Survey Digital Data Series DDS-80.

Wolfe, E.W., ed, 1988, The Pu`u `Ō `ō eruption of Kīlauea Volcano: U.S. Geological Survey Professional Paper 1463, 251 p.

\section{Mauna Loa}

Selected References

$1302-02=$

\section{Eruption}

Baher, S., Thurber, C., Roberts, K., and Rowe, C., 2003, Relocation of seismicity preceding the 1984 eruption of Mauna Loa volcano, Hawai $i$-Delineation of a possible failed rift: Journal of Volcanology and Geothermal Research, v. 128, p. 327-339.

Crisp, J., Cashman, K.V., Bonini, J.A., Hougen, S.B., and Pieri, D.C., 1994, Crystallization history of the 1984 Mauna Loa lava flow: Journal of Geophysical Research, v. 99, no. B4, p. 7177-7198.

Koyanagi, R.Y., 1987, Seismicity associated with volcanism in Hawai i-Application to the 1984 eruption of Mauna Loa volcano: U.S. Geological Survey Open-File Report 87-277, 74 p.

Lockwood, J.P., Banks, N.G., English, T.T., Greenland, L.P., Jackson, D.B., Johnson, D.J., Koyanagi, R.Y., McGee, K.A., Okamura, A.T., and Rhodes, J.M., 1985, The 1984 eruption of Mauna Loa Volcano, Hawai i: Eos, Transactions, American Geophysical Union, v. 66, no. 16, p. 169-171.

Lockwood, J.P., and Lipman, P.W., 1987, Holocene eruptive history of Mauna Loa volcano: U.S. Geological Survey Professional Paper 1350, p. 509-535.

Rhodes, J.M., 1988, Geochemistry of the 1984 Mauna Loa eruption-Implications for magma storage and supply: Journal of Geophysical Research, v. 93, no. B5, p. 4453-4466.

Rhodes, J.M., and Lockwood, J.P., eds., 1995, Mauna Loa revealed-Structure, composition, history, and hazards: American Geophysical Union, Geophysical Monograph 92, $348 \mathrm{p}$.

Russell, J.K., 1987, Crystallization and vesiculation of the 1984 eruption of Mauna Loa: Journal of Geophysical Research, v. 92, no. B13, p. 13731-13743. 
Comprehensive References

2002-Present Unrest

Amelung, F., and Walter, T., 2004, Constraints on the geometry of the magma chamber of Mauna Loa volcano, Hawai' i, from InSAR data [abs.]: Eos, Transactions, American Geophysical Union, v. 87, no. 47, Fall Meeting Supplement, Abstract G51A-0074.

Amelung, F., Yun, S., Walter, T.R., Segall, P., and Kim, S., 2007, Stress control of deep rift intrusion at Mauna Loa volcano, Hawai'i: Science, v. 316, no. 5827, p. 10261030 .

Miklius, A., and Cervelli, P., 2003, Interaction between Kīlauea and Mauna Loa: Nature, v. 421, p. 229.

Okubo, P.G., Wolfe, C.J., Nakata, J.S., Koyanagi, S.K., and Uribe, J.O., 2005, A closer look at recent deep Mauna Loa seismicity [abs.]: Eos, Transactions, American Geophysical Union, v. 86, no. 52, Fall Meeting Supplement, Abstract V21D0649.

Poland, M.P., 2006, InSAR observations of surface deformation associated with volcanotectonic activity at Kīlauea and Mauna Loa volcanoes, Hawai i [abs.]: Eos, Transactions, American Geophysical Union, v. 87, no. 52, Fall Meeting Supplement, Abstract G53A-0873.

Smithsonian Institution, 2002, Mauna Loa: Bulletin of the Global Volcanism Network, v. 27, no. 9.

Smithsonian Institution, 2004, Mauna Loa: Bulletin of the Global Volcanism Network, v. 27, no. 9 .

\title{
Mount St. Helens
}

\author{
1201-05-
}

Selected References

\section{0-1986 Eruption:}

Alidibirov, M.A., 1995, A model for the mechanism of the May 18, 1980 Mount St. Helens blast: Journal of Volcanology and Geothermal Research, v. 66, p. 217225.

Brantley, S.R., and Myers, B., 1997, Mount St. Helens-From the 1980 eruption to 1996: U.S. Geological Survey Open-File Report 97-70, 2 p.

Cashman, K.V., 1988, Crystallization of Mount St. Helens 1980-1986 dacite-A quantitative textural approach: Bulletin of Volcanology, v. 50, p. 194-209. 
Cashman, K.V., 1992, Groundmass crystallization of Mount St. Helens dacite, 19801986 - A tool for interpreting shallow magmatic processes: Contributions to Mineralogy and Petrology, v. 109, p. 431-449.

Christiansen, R.L., 1980, Eruption of Mt. St. Helens-Volcanology: Nature, v. 285, p. 531-533.

Endo, E.T., Dzurisin, D., and Swanson, D.A., 1990, Geophysical and observational constraints for ascent rates of dacitic magma at Mount St. Helens, in Ryan, M.P., ed., Magma transport and storage: New York, John Wiley and Sons, p. 317-334.

Fink, J.H., Malin, M.C., and Anderson, S.W., 1990, Intrusive and extrusive growth of the Mount St. Helens lava dome: Nature, v. 348, p. 435-437.

Fisher, R.V., 1990, Transport and deposition of a pyroclastic surge across an area of high relief_-The 18 May 1980 eruption of Mount St. Helens, Washington: Geological Society of America Bulletin, v. 102, p. 1038-1054.

Gerlach, T.M., and McGee, K.A., 1994, Total sulfur dioxide emissions and pre-eruption vapor saturated magma at Mount St. Helens, 1980-88: Geophysical Research Letters, v. 21, p. 2833-2836.

Glicken, H., 1996, Rockslide-debris avalanche of May 18, 1980, Mount St. Helens, Washington: U.S. Geological Survey Open-File Report 96-677, unpaginated.

Lipman, P.W., and Mullineaux, D.R., eds., 1981, The 1980 eruptions of Mount St. Helens, Washington: U.S. Geological Survey Professional Paper 1250, 844 p.

Malone, S.D., 1990, Mount St. Helens, the 1980 re-awakening and continuing seismic activity: Geoscience Canada, v. 17, p. 146-150.

McGee, K.A., 1992, Volcanic-plume data from Mount St. Helens during 1980-88: U.S. Geological Survey Open-File Report 92-361, 24 p.

McGee, K.A., and Casadevall, T.J., 1994, A compilation of sulfur dioxide and carbon dioxide emission-rate data from Mount St. Helens during 1980-1988: U.S. Geological Survey Open-File Report 94-212, 19 p.

Newhall, C.G., 2000, Mount St. Helens, master teacher: Science, v. 288, no. 5469, p. 1181-1183.

Pallister, J.S., Hoblitt, R.P., Crandell, D.R., and Mullineaux, D.R., 1992, Mount St. Helens a decade after the 1980 eruptions-Magmatic models, chemical cycles, and a revised hazards assessment: Bulletin of Volcanology, v. 54, p. 126-146. 
Rutherford, M.J., Sigurdsson, H., Carey, S., and Davis, A., 1985, The May 18, 1980, eruption of Mount St. Helens, I-Melt composition and experimental phase equilibria: Journal of Geophysical Research, v. 90, p. 2929-2947.

Sisson, T.W., 1995, Blast ashfall deposit of May 18, 1980, at Mount St. Helens, Washington: Journal of Volcanology and Geothermal Research, v. 66, p. 203-216.

Swanson, D.A., 1990, A decade of dome growth at Mount St. Helens, 1980-90: Geoscience Canada, v. 17, p. 154-157.

Swanson, D.A., and Holcomb, R.T., 1990, Regularities in growth of the Mount St. Helens dacite dome 1980-1986, in Fink, J.H., ed., Lava flows and domes, emplacement mechanisms and hazard implications: Berlin, Springer-Verlag, International Association of Volcanology and Chemistry of the Earth's Interior, Proceedings in Volcanology 2, p. 3-24.

Weaver, C.S., Zollweg, J.E., and Malone, S.D., 1983, Deep earthquakes beneath Mount St. Helens-Evidence for magmatic gas transport?: Science, v. 221, p.1391-1394.

\section{Comprehensive References}

\section{9-1990 Eruption}

Mastin, L., 1992, Correlation between atmospheric precipitation and recent explosions at Mount St. Helens, Washington: Earthquakes and Volcanoes, v. 23, p. 74-76.

Mastin, L.G., 1994, Explosive tephra emissions at Mount St. Helens, 1989-1991-The violent escape of magmatic gas following storms?: Geological Society of America Bulletin, v. 106, p. 175-185.

Mastin, L.G., and Myers, B., 1992, Shallow explosion-like seismicity and steam-and-ash emissions at Mount St. Helens, August 1989-June1991: Washington Geology, v. 20, p. $12-18$.

Moran, S.C., 1994, Seismicity at Mount St. Helens, 1987-1992-Evidence for repressurization of an active magmatic system: Journal of Geophysical Research, v. 99, p. 4341-4354.

Smithsonian Institution, 1989, Mount St. Helens: Scientific Event Alert Network (SEAN) Bulletin, v. 14, nos. 8, 10, 11 and 12.

Smithsonian Institution, 1990, Mount St. Helens: Bulletin of the Global Volcanism Network, v. 15 , no. 4.

Wolf, E.W., and Malone, S.D., 1993, Mount St. Helens, in Annual report of the world volcanic eruptions in 1990: Bulletin of Volcanic Eruptions, no. 30, p. 71-73. 
Wolf, E.W., Malone, S.D., and Jonientz-Trisler, C., 1992, Mount St. Helens, in Annual report of the world volcanic eruptions in 1989: Bulletin of Volcanic Eruptions, no. 29 , p. $76-78$.

\section{Comprehensive References}

1990-1991 Eruption

Ellis, J.S., and Sullivan, T.J., 1991, ADPIC calculated volcanic ash cloud transport and fallout from the 20 December 1990 Mount Saint Helens puff [abs.], in Casadevall, T.J., ed., First international symposium on volcanic ash and aviation safety: U.S. Geological Survey Circular 1065, p. 18.

Mastin, L., 1992, Correlation between atmospheric precipitation and recent explosions at Mount St. Helens, Washington: Earthquakes and Volcanoes, v. 23, p. 74-76.

Mastin, L.G., 1994, Explosive tephra emissions at Mount St. Helens, 1989-1991-The violent escape of magmatic gas following storms?: Geological Society of America Bulletin, v. 106, p. 175-185.

Mastin, L.G., and Myers, B., 1992, Shallow explosion-like seismicity and steam-and-ash emissions at Mount St. Helens, August 1989-June1991: Washington Geology, v. 20, p. 12-18.

Moran, S.C., 1994, Seismicity at Mount St. Helens, 1987-1992-Evidence for repressurization of an active magmatic system: Journal of Geophysical Research, v. 99, p. 4341-4354.

Smithsonian Institution, 1990, Mount St. Helens: Bulletin of the Global Volcanism Network, v. 15, nos. 10 and 11.

Smithsonian Institution, 1991, Mount St. Helens: Bulletin of the Global Volcanism Network, v. 16, no. 1.

Wolf, E.W., and Malone, S.D., 1993, Mount St. Helens, in Annual report of the world volcanic eruptions in 1990: Bulletin of Volcanic Eruptions, no. 30, p. 71-73.

Wolf, E.W., and Malone, S.D., 1994, Mount St. Helens, in Annual report of the world volcanic eruptions in 1991: Bulletin of Volcanic Eruptions, no. 31, p. 88-90.

Comprehensive References

\section{Unrest}

Smithsonian Institution, 1995, Mount St. Helens: Bulletin of the Global Volcanism Network, v. 20, nos. 9 and 11/12. 
Smithsonian Institution, 1996, Mount St. Helens: Bulletin of the Global Volcanism Network, v. 21, no. 6 .

Comprehensive References

1998 Unrest

Smithsonian Institution, 1998, Mount St. Helens: Bulletin of the Global Volcanism Network, v. 23, nos. 5, 6 and 7.

Selected References

\title{
2004-2008 Eruption
}

Iverson, R.M., Dzurisin, D., Gardner, C.A., Gerlach, T.M., LaHusen, R.G., Lisowski, M., Major, J.J., Malone, S.D., Messerich, J.A., Moran, S.C., Pallister, J.S., Qamar, A.I., Schilling, S.P., and Vallance, J.W., 2006, Dynamics of seismogenic volcanic extrusion at Mount St. Helens in 2004-05: Nature, v. 444, p. 439-443.

Rowe, M.C., Thornber, C.R., Gooding, D.J., and Pallister, J.S., 2008, Catalog of Mount St. Helens 2004-2005 tephra samples with major- and trace-element geochemistry: U.S. Geological Survey Open-File Report 2008-1131, 11 p.

Sherrod, D.R., Scott, W.E., and Stauffer, P.H., eds., 2008, A volcano rekindled-The renewed eruption of Mount St. Helens, 2004-2006: U.S. Geological Survey Professional Paper 1750, in press.

Thornber, C.R., Pallister, J.S., Rowe, M.C., McConnell, S., Herriott, T.M., Eckberg, A., Stokes, W.C., Cornelius, D.J., Conrey, R.M., Hannah, T., Taggart, J.E., Jr., Adams, M., Lamothe, P.J., Budahn, J.R., and Knaack, C.M., 2008, Catalog of Mount St. Helens 2004-2007 dome samples with major- and trace-element chemistry: U.S. Geological Survey Open-File Report 2008-1130, 12 p.

\section{Mount Hood}

\author{
1202-01-
}

Comprehensive References

\section{Unrest}

Anonymous, 1990, Seismic activity brief at Mount Hood: Washington Geologic Newsletter, v. 18, p. 14.

Malone, S.D., 1996, Volcanic earthquake hazards in the Pacific Northwest [abs.]: Geological Society of America Abstracts with Programs, Cordilleran Section Meeting, v. 28, no. 5, p. 88.

Rite, A., and Iyer, H.M., 1981, July 1980 Mt. Hood earthquake swarm: U.S. Geological Survey Open-File Report 81-48, 22 p. 
Smithsonian Institution, 1980, Mount Hood: Scientific Event Alert Network (SEAN) Bulletin, v. 5, no. 7.

Comprehensive References

\section{Unrest}

Jones, J., and Malone, S.D., 2005, Mount Hood earthquake activity-Volcanic or tectonic origins?: Bulletin of the Seismological Society of America, v. 95, no. 3, p. $818-832$.

Norris, R.D., Weaver, C.S., Meagher, K.L., Qamar, A., and Blakely, R.J., 1999, Earthquake swarms at Mount Hood; relation to geologic structure [abs.]: Seismological Research Letters, v. 70, no. 2, p. 218.

Smithsonian Institution, 1999, Mount Hood: Bulletin of the Global Volcanism Network, v. 24 , no. 1 .

Comprehensive References

\section{Unrest}

Jones, J., and Malone, S.D., 2005, Mount Hood earthquake activity-Volcanic or tectonic origins?: Bulletin of the Seismological Society of America, v. 95, no. 3, p. 818-832.

Smithsonian Institution, 2001, Mount Hood: Bulletin of the Global Volcanism Network, v. 26 , no. 36 .

Comprehensive References

\section{Unrest}

Jones, J., and Malone, S.D., 2005, Mount Hood earthquake activity-Volcanic or tectonic origins?: Bulletin of the Seismological Society of America, v. 95, no. 3, p. 818-832.

Saar, M., and Manga, M., 2002, Seismicity induced by groundwater recharge at Mt. Hood, Oregon, and its implications for hydrogeologic properties [abs.]: Eos, Transactions, American Geophysical Union, v. 83, no. 47, Fall Meeting Supplement, Abstract G51A-0944.

Saar, M., and Manga, M., 2003a, Fluid flow and the state of stress at Mt. Hood, Oregon, inferred from microseismicity induced by groundwater recharge [abs.]: European Geophysical Society, Geophysical Research Abstracts, v. 5, p. 02375. 
Saar, M.O., and Manga, M., 2003b, Seismicity induced by seasonal groundwater recharge at Mt. Hood, Oregon: Earth and Planetary Science Letters, v. 214, p. 605-618.

Smithsonian Institution, 2002, Mount Hood: Bulletin of the Global Volcanism Network, v. 27 , no. 7 .

\section{South Sister}

1202-08-

\section{Comprehensive References}

\section{8-Present Unrest}

Dzurisin, D., Endo, E.T., Iwatsubo, E.Y., Lisowski, M., Poland, M.P., and Wicks, C.W., 2003, New results from a proposed PBO Cascade volcano cluster-II, InSAR, GPS, and tilt-leveling data from the Three Sisters area, central Oregon [abs.]: Geological Society of America Abstracts with Programs, v. 35, no. 6, p. 563.

Dzurisin, D., Lisowski, M., Moran, S.C., Wicks, C.W., Poland, M.P., and Endo, E.T., 2004, An ongoing episode of magmatic inflation at the Three Sisters volcanic center, central Oregon Cascade Range-Inferences from recent geodetic and seismic observations [abs.]: Eos, Transactions, American Geophysical Union, v. 85, no. 47, Abstract G42A-04.

Dzurisin, D., Lisowski, M., Wicks, C.W., Poland, M.P., and Endo, E.T., 2006, Geodetic observations and modeling of magmatic inflation at the Three Sisters volcanic center, central Oregon Cascade Range, USA: Journal of Volcanology and Geothermal Research, v. 150 , p. 35-54.

Evans, W.C., Ingebritsen, S.E., Wicks, C.W., Mariner, R.H., Kennedy, B.M., and van Soest, M.C., 2002, Magma intrusion rate in the Three Sisters area of the central Oregon Cascades inferred by different methods [abs.]: Geological Society of America Abstracts with Programs, v. 34, no. 5, p. 91.

Evans, W.C., Mariner, R.H., Ingebritsen, S.E., Kennedy, B.M., van Soest, M.C., and Huebner, M.A., 2002, Report of hydrologic investigations in the Three Sisters area of central Oregon, summer 2001: U.S. Geological Survey Water-Resources Investigations Report 02-4061, $13 \mathrm{p}$.

Evans, W.C., van Soest, M.C., Mariner, R.H., Hurwitz, S., Ingebritsen, S.E., Wicks, C.W., Jr., and Schmidt, M.E., 2004, Magmatic intrusion west of Three Sisters, central Oregon, USA - The perspective from spring chemistry: Geology, v. 32, p. 69-72.

Gerlach, T.M., McGee, K.A., and Doukas, M.P, 2002, $\mathrm{CO}_{2}$ and $\mathrm{H}_{2} \mathrm{~S}$ in the air over the ground-swelling area west of South Sister Volcano, central Oregon Cascade 
Range [abs.]: Geological Society of America Abstracts with Programs, v. 34, no. 5, p. 91.

Ingebritsen, S.E., Evans, W.C., Mariner, R.H., Schmidt, M., and Hurwitz, S., 2002, Long- and short-term intrusion rates in the Three Sisters region, central Oregon Cascade Range [abs.]: Geological Society of America Abstracts with Programs, v. 34, no. 6, p. 526-527.

Lisowski, M., Dzurisin, D., Endo, E.T., Poland, M.P., and Iwatsubo, E.Y., 2002, What's up in the Cascades? I-Three Sisters Volcanic Center, Central Oregon [abs.]: Eos, Transactions, American Geophysical Union, v. 83, p. 47, Fall Meeting Supplement, Abstract T12A-1294.

Lisowski, M., Dzurisin, D., and Wicks, C.W., 2007, Continuing inflation at Three Sisters volcanic center, central Oregon Cascade Range, USA, from GPS, InSAR, and leveling observations [abs.]: Eos, Transactions, American Geophysical Union, v. 88, p. 52, Fall Meeting Supplement, Abstract V53C-1425.

Moran, S.C., 2004, Seismic monitoring at Cascade volcanic centers, 2004-Status and recommendations: U.S. Geological Survey Scientific Investigations Report 2004$5211,28 \mathrm{p}$.

Scott, W.E., 2002, USGS response to ongoing crustal uplift at Three Sisters volcanic center, Oregon [abs.]: Geological Society of America Abstracts with Programs, v. 34 , no. 5 , p. 91 .

Smithsonian Institution, 2001, South Sister: Bulletin of the Global Volcanism Network, v. 26 , no. 5 .

Smithsonian Institution, 2002, South Sister: Bulletin of the Global Volcanism Network, v. 27 , no. 6 .

Smithsonian Institution, 2004, South Sister: Bulletin of the Global Volcanism Network, v. 29 , no. 6 .

Smithsonian Institution, 2005, South Sister: Bulletin of the Global Volcanism Network, v. 30 , no. 12 .

van Soest, M.C., Evans, W.C., Mariner, R.H., Kennedy, B.M., and Schmidt, M.E., 2003, The geochemistry of the geothermal and hydrologic system of the Separation Creek drainage, Three Sisters area, central Oregon, Cascades [abs.]: Geological Society of America Abstracts with Programs, v. 35, no. 6, p. 321.

Wicks, C.W., Dzurisin, D., Ingebritsen, S., Thatcher, W., Lu, Z., and Iverson, J., 2001, Magmatic activity beneath the quiescent Three Sisters volcanic center, central Oregon Cascade Range, USA, inferred from Satellite InSAR [abs.]: Eos, 
Transactions, American Geophysical Union, v. 82, p. 47, Fall Meeting

Supplement, Abstract G31C-0155.

Wicks, C.W., Jr., Dzurisin, D., Ingebritsen, S., Thatcher, W., Lu, Z., and Iverson, J., 2002a, Magmatic activity beneath the quiescent Three Sisters volcanic center, central Oregon Cascade Range, USA: Geophysical Research Letters, v. 29, no. 7, p. 1122, doi 10.1029/2001GL014205.

Wicks, C.W., Jr., Dzurisin, D., Ingebritsen, S.E., Thatcher, W.R., Lu, Z., and Iverson, J., 2002b, Ongoing magma intrusion beneath the Three Sisters volcanic center, central Oregon Cascade Range, USA, inferred from satellite InSAR [abs.]:

Geological Society of America Abstracts with Programs, v. 34, no. 5, p. 90-91.

\section{Medicine Lake}

1203-02-

Comprehensive References

\section{8-1989 Unrest}

Dzurisin, D., Donnelly-Nolan, J.M., Evans, J.R., and Walter, S.R, 1991, Crustal subsidence, seismicity, and structure near Medicine Lake volcano, California: Journal of Geophysical Research, v. 96, no. B10, p. 16319-16333.

Poland, M., Bürgmann, R., Dzurisin, D., Lisowski, M., Masterlark, T., Owen, S., and Fink, J., 2006, Constraints on the mechanism of long-term, steady subsidence at Medicine Lake volcano, northern California, from GPS, leveling, and InSAR: Journal of Volcanology and Geothermal Research, v. 150, p. 55-78.

Smithsonian Institution, 1988, Medicine Lake: Scientific Event Alert Network (SEAN) Bulletin, v. 13, nos. 9, 10 and 11.

\section{Long Valley Caldera}

120314-A

Selected References

\section{0-Present Unrest}

Battaglia, M., Segall, P., and Roberts, C., 2003, The mechanics of unrest at Long Valley caldera, California, 2-Constraining the nature of the source using geodetic and micro-gravity data: Journal of Volcanology and Geothermal Research, v. 127, p. 219-245.

Cook, A.C., Hainsworth, L.J., Sorey, M.L., Evans, W.C., and Southon, J.R., 2001, Radiocarbon studies of plant leaves and tree rings from Mammoth Mountain, $\mathrm{CA}-\mathrm{A}$ long-term record of magmatic $\mathrm{CO}_{2}$ release: Chemical Geology, v. 177, p. 117-131. 
Dreger, D.S., Tkalcic, H., and Johnston, M., 2000, Dilational processes accompanying earthquakes in the Long Valley Caldera: Science, v. 288, no. 5463, p. 122-125.

Evans, W.C., Sorey, M.L., Cook, A.C., Kennedy, B.M., Shuster, D.L., Colvard, E.M., White, L.D., and Huebner, M.A., 2002, Tracing and quantifying magmatic carbon discharge in cold groundwaters - Lessons learned from Mammoth Mountain, USA: Journal of Volcanology and Geothermal Research, v. 114, p. 291-312.

Ewert, J.W., and Harpel, C.J., 2000, Bibliography of literature pertaining to Long Valley Caldera and associated volcanic fields: U.S. Geological Survey Open-File Report 00-221, $156 \mathrm{p}$.

Foulger, G.R., Julian, B.R., Hill, D.P., Pitt, A.M., Malin, P.E., and Shalev, E., 2004, Nondouble-couple microearthquakes at Long Valley caldera, California, provide evidence for hydraulic fracturing: Journal of Volcanology and Geothermal Research, v. 132, p. 45-71.

Gerlach, T.M., Doukas, M.P., McGee, K.A., and Kessler, R., 2001, Soil efflux and total emission rates of magmatic $\mathrm{CO}_{2}$ at the Horseshoe Lake tree kill, Mammoth Mountain, California, 1995-1999: Chemical Geology, v. 177, p. 101-116.

Hill, D.P., 2006, Unrest in Long Valley Caldera, California, 1978-2004, in Troise, C., De Natale, G., and Kilburn, C.R.J., eds., Mechanisms of activity and unrest at large calderas: Geological Society, London, Special Publication 269, p. 1-24.

Hill, D.P., Langbein, J.O., and Prejean, S., 2003, Relations between seismicity and deformation during unrest in Long Valley Caldera, California, from 1995 through 1999: Journal of Volcanology and Geothermal Research, v. 127, p. 175-193.

Hough, S.E., Dollar, R.S., and Johnson, P., 2000, The 1998 earthquake sequence south of Long Valley Caldera, California-Hints of magmatic involvement: Bulletin of the Seismological Society of America, v. 90, no. 3, p. 752-763.

Langbein, J.O., 2003, Deformation of the Long Valley Caldera, California-Inferences from measurements from 1988 to 2001: Journal of Volcanology and Geothermal Research, v. 127, p. 247-267.

Mukhopadhyay, B., 2002, Water-Rock interactions in the basement beneath Long Valley Caldera-An oxygen isotope study of the Long Valley Exploratory Well drill cores: Journal of Volcanology and Geothermal Research, v. 116, p. 325-359.

Newman, A.V., Dixon, T.H., and Gourmelen, N., 2006, A four-dimensional viscoelastic deformation model for Long Valley Caldera, California, between 1995 and 2000: Journal of Volcanology and Geothermal Research, v. 150, p. 244-269. 
Newman, A.V., Dixon, T.H., Ofoegbu, G.I., and Dixon, J.E., 2001, Geodetic and seismic constraints on recent activity at Long Valley Caldera, California-Evidence for viscoelastic rheology: Journal of Volcanology and Geothermal Research, v. 105, p. 183-206.

Prejean, S.G., and Ellsworth, W.L., 2001, Observations of earthquake source parameters at $2 \mathrm{~km}$ depth in the Long Valley Caldera, eastern California: Bulletin of the Seismological Society of America, v. 91, no. 2, p. 165-177.

Roeloffs, E., Sneed, M., Galloway, D.L., Sorey, M.L., Farrar, C.D., Howle, J.F., and Hughes, J., 2003, Water-level changes induced by local and distant earthquakes at Long Valley caldera, California: Journal of Volcanology and Geothermal Research, v. 127, p. 269-303.

Rogie, J.D., Kerrick, D.M., Sorey, M.L., Chiodini, G., and Galloway, D.L., 2001, Dynamics of carbon dioxide emission at Mammoth Mountain, California: Earth and Planetary Science Letters, v. 188, p. 535-541.

Sorey, M.L., McConnell, V.S., and Roeloffs, E., 2003, Summary of recent research in Long Valley Caldera, California: Journal of Volcanology and Geothermal Research, v. 127, p. 165-173.

Stephens, J.C., and Hering, J.G., 2002, Comparative characterization of volcanic ash soils exposed to decade-long elevated carbon dioxide concentrations at Mammoth Mountain, California: Chemical Geology, v. 186, p. 301-313.

Tiampo, K.F., Rundle, J.B., Fernandez, J., and Langbein, J.O., 2000, Spherical and ellipsoidal volcanic sources at Long Valley caldera, California, using a genetic algorithm inversion technique: Journal of Volcanology and Geothermal Research, v. 102, p. 189-206.

Tizzani, P., Berardino, P., Casu, F., Euillades, P., Manzo, M., Ricciardi, G.P., Zeni, G., and Lanari, R., 2007, Surface deformation of Long Valley caldera and Mono Basin, California, investigated with the SBAS-InSAR approach: Remote Sensing of Environment, v. 108, p. 277-289.

\section{Yellowstone Caldera}

1205-01-

Selected References

\section{0-Present Unrest}

Arnet, F., Kahle, H., Klingele, E., Smith, R.B., Meertens, C.M., and Dzurisin, D., 1997, Temporal gravity and height changes of the Yellowstone caldera, 1977-1994: Geophysical Research Letters, v. 24, no. 22, p. 2741-2744. 
Clark, J.F., and Turekian, K.K., 1990, Time scale of hydrothermal water-rock reactions in Yellowstone National Park based on radium isotopes and radon: Journal of Volcanology and Geothermal Research, v. 40, p. 169-180.

Dobson, P.F., Kneafsey, T.J., Hulen, J., and Simmons, A., 2003, Porosity, permeability, and fluid flow in the Yellowstone geothermal system, Wyoming: Journal of Volcanology and Geothermal Research, v. 123, p. 313-324.

Dzurisin, D., Wicks, C.W., Jr., Thatcher, W., 1999, Renewed uplift at the Yellowstone Caldera measured by leveling surveys and satellite radar interferometry: Bulletin of Volcanology, v. 61, no. 6, p. 349-355.

Dzurisin, D., and Yamashita, K.M., 1987, Vertical surface displacements at Yellowstone Caldera, Wyoming, 1976-1986: Journal of Geophysical Research, v. 92, no. B13, p. $13753-13766$.

Dzurisin, D., Yamashita, K.M., and Kleinman, J.W., 1994, Mechanisms of crustal uplift and subsidence at the Yellowstone caldera, Wyoming: Bulletin of Volcanology, $v$. 56, no. 4, p. 261-270.

Evans, W.C., Bergfeld, D., van Soest, M.C., Huebner, M.A., Fitzpatrick, J., and Revesz, K.M., 2006, Geochemistry of low-temperature springs northwest of Yellowstone caldera-Seeking the link between seismicity, deformation, and fluid flow: Journal of Volcanology and Geothermal Research, v. 154, p. 169-180.

Finn, C.A., and Morgan, L.A., 2002, High-resolution aeromagnetic mapping of volcanic terrain, Yellowstone National Park: Journal of Volcanology and Geothermal Research, v. 115, p. 207-231.

Friedman, I., and Norton, D.R., 1990, Anomalous chloride flux discharges from Yellowstone National Park: Journal of Volcanology and Geothermal Research, v. 42 , p. 225-234.

Hellman, M.J., and Ramsey, M.S., 2004, Analysis of hot springs and associated deposits in Yellowstone National Park using ASTER and AVIRIS remote sensing: Journal of Volcanology and Geothermal Research, v. 135, p. 195-219.

Hurwitz, S., Lowenstern, J.B., and Heasler, H., 2007, Spatial and temporal geochemical trends in the hydrothermal system of Yellowstone National Park-Inferences from river solute fluxes: Journal of Volcanology and Geothermal Research, v. 162, p. 149-171.

Husen, S., Smith, R.B., and Waite, G.P., 2004, Evidence for gas and magmatic sources beneath the Yellowstone volcanic field from seismic tomographic imaging: Journal of Volcanology and Geothermal Research, v. 131, p. 397-410. 
Lowenstern, J.B., Smith, R.B., and Hill, D.P., 2006, Monitoring super-volcanoesGeophysical and geochemical signals at Yellowstone and other large caldera systems: Philosophical Transactions of the Royal Society A, v. 364, p. 2055-2072.

Meertens, C.M., and Smith, R.B., 1991, Crustal deformation of the Yellowstone caldera from first GPS measurements—1987-1989: Geophysical Research Letters, v. 18, no. 9 , p. 1763-1766.

Morgan, L.A., ed., 2007, Integrated geoscience studies in the greater Yellowstone areaVolcanic, tectonic, and hydrothermal processes in the Yellowstone geoecosystem: U.S. Geological Survey Professional Paper 1717, 532 p.

Morgan, L.A., Shanks, W.C., III, Lovalvo, D.A., Johnson, S.Y., Stephenson, W.J., Pierce, K.L., Harlan, S.S., Finn, C.A., Lee, G., Webring, M., Schulze, B., Duhn, J., Sweeney, R., and Balistrieri, L., 2003, Exploration and discovery in Yellowstone Lake-Results from high-resolution sonar imaging, seismic reflection profiling, and submersible studies: Journal of Volcanology and Geothermal Research, v. 122, p. 221-242.

Parry, W.T., and Bowman, J.R., 1990, Chemical and stable isotopic models for Boundary Creek warm springs, southwestern Yellowstone National Park, Wyoming: Journal of Volcanology and Geothermal Research, v. 43, p. 133-157.

Pierce, K.L., and Morgan, L.A., 1992, The track of the Yellowstone hot spotVolcanism, faulting, and uplift: Geological Society of America Memoir 179, ch. $1,52 \mathrm{p}$.

Sheppard, D.S., Truesdell, A.H., and Janik, C.J., 1992, Geothermal gas compositions in Yellowstone National Park, USA: Journal of Volcanology and Geothermal Research, v. 51, p. 79-93.

Smith, R.B., and Braile, L.W., 1994, The Yellowstone hotspot: Journal of Volcanology and Geothermal Research, v. 61, p. 121-187.

Smith, R.B., Reilinger, R., Meertens, C., Hollis, J., Holdahl, S., Dzurisin, D., Gross, W., and Klingele, E., 1989, What's moving at Yellowstone?-The 1987 crustal deformation survey from GPS, leveling, precision gravity, and trilateration: Eos, Transactions, American Geophysical Union, v. 70, p. 113-125.

Strasser, P., Strasser, S., and Pulliam, B., 1989, Investigations of patterns of minor behavior of Steamboat geyser, 1982-1984: Geyer Observation and Study Association Transactions, v. 2, p. 43-70 (see GOSA Web site).

Waite, G.P., and Smith, R.B., 2002, Seismic evidence for fluid migration accompanying subsidence of the Yellowstone caldera: Journal of Geophysical Research, v. 107, no. B9, p. 2177-2192, doi:10.1029/2001JB000586. 
Washington State University, 2006, Scientific research and science in Yellowstone National Park: Washington State University Library, Bibliographic database, [available at http://www.wsulibs.wsu.edu/yellowstone/, last updated November $13,2006]$.

Werner, C., and Brantley, S., 2003, $\mathrm{CO}_{2}$ emissions from the Yellowstone volcanic system: Geochemistry, Geophysics, Geosystems, v. 4, no. 7, 27 p.

Werner, C., Brantley, S.L., and Boomer, K., 2000, $\mathrm{CO}_{2}$ emissions related to the Yellowstone volcanic system, 2-Statistical sampling, total degassing, and transport mechanisms: Journal of Geophysical Research, v. 105, no. B5, p. 1083110846.

White, D.E., Hutchinson, R.A., and Smith, T.E.C., 1988, The geology and remarkable thermal activity of Norris Geyser Basin, Yellowstone National Park, Wyoming: U.S. Geological Survey Professional Paper 1456, 84 p.

Wicks, C.W., Jr., Thatcher, W., and Dzurisin, D., 1998, Migration of fluids beneath Yellowstone Caldera inferred from satellite radar interferometry: Science, New Series, v. 282, no. 5388, p. 458-462.

Wicks, C.W., Thatcher, W., Dzurisin, D., and Svarc, J., 2006, Uplift, thermal unrest and magma intrusion at Yellowstone caldera: Nature, v. 440, p. 72-75.

Xu, Y., Schoonen, M.A.A., Nordstrom, D.K., Cunningham, K.M., and Ball, J.W., 2000, Sulfur geochemistry of hydrothermal waters in Yellowstone National Park, Wyoming, USA, II-Formation and decomposition of thiosulfate and polythionate in Cinder Pool: Journal of Volcanology and Geothermal Research, v. 97, p. 407-423.

\section{Kiska}

1101-02-

\section{Comprehensive References \\ 1990 Eruption}

Coombs, M.L., White, S.M., and Scholl, D.W., 2007, Massive edifice failure at Aleutian arc volcanoes: Earth and Planetary Science Letters, v. 256, p. 403-418.

Miller, T.P., McGimsey, R.G., Richter, D.H., Riehle, J.R., Nye, C.J., Yount, M.E., and Dumoulin, J.A., 1998, Catalogue of the historically active volcanoes of Alaska: U.S. Geological Survey Open-File Report 98-582, 104 p. 
Seliverstov, N.I., Yogodzinski, E., and Reeder, J.W., 1993, Kiska, in Annual report of the world volcanic eruptions in 1990: Bulletin of Volcanic Eruptions, no. 30, p. 6061. [appears in Bulletin of Volcanology, v. 55, 91-page supplement, March 1993]

Smithsonian Institution, 1990, Kiska: Bulletin of the Global Volcanism Network, v. 15, no. 5 .

\section{Sugarloaf Peak (Semisopochnoi)}

1101-06-

Comprehensive References

1987 Eruption

Miller, T.P., McGimsey, R.G., Richter, D.H., Riehle, J.R., Nye, C.J., Yount, M.E., and Dumoulin, J.A., 1998, Catalogue of the historically active volcanoes of Alaska: U.S. Geological Survey Open-File Report 98-582, 104 p.

Reeder, J.W., 1990, Sugarloaf, in Annual report of the world volcanic eruptions in 1987: Bulletin of Volcanic Eruptions, v. 27, p. 36. [appears in Bulletin of Volcanology, v. 52, 80-page supplement, October 1990]

Smithsonian Institution, 1987, Semisopochnoi: Scientific Event Alert Network (SEAN) Bulletin, v. 12, no. 4.

Comprehensive References

\section{Gareloi Volcano}

1101-07-

\section{Eruption}

Miller, T., 1982, Gareloi, in Annual report of the world volcanic eruptions in 1980: Bulletin of Volcanic Eruptions, no. 20, p. 67-68.

Miller, T.P., McGimsey, R.G., Richter, D.H., Riehle, J.R., Nye, C.J., Yount, M.E., and Dumoulin, J.A., 1998, Catalog of the historically active volcanoes of Alaska: U.S. Geological Survey Open-File Report 98-582, 104 p.

Sedlacek, W.A., Mroz, E.J., and Heiken, G., 1981, Stratospheric sulfate from the Gareloi eruption, 1980: contribution to the "ambient" aerosol by a poorly documented volcanic eruption: Geophysical Research Letters, v. 8, no. 7, p. 761-764.

Smithsonian Institution, 1980, Gareloi: Scientific Event Alert Network (SEAN) Bulletin, v. 5, nos. 8-9 and 11 . 
Comprehensive References

$\underline{1982}$ Eruption

Kienle, J., Billington, S., and Mutschlecner, P., 1984, Gareloi, in Annual report of the world volcanic eruptions in 1982: Bulletin of Volcanic Eruptions, no. 22, p. 59. [appears in Bulletin of Volcanology, v. 49, 52-page supplement, January 1987]

Miller, T.P., McGimsey, R.G., Richter, D.H., Riehle, J.R., Nye, C.J., Yount, M.E., and Dumoulin, J.A., 1998, Catalog of the historically active volcanoes of Alaska: U.S. Geological Survey Open-File Report 98-582, 104 p.

Smithsonian Institution, 1982, Gareloi: Scientific Event Alert Network (SEAN) Bulletin v. 7 , no. 2 .

Comprehensive References

1987 Eruption

Browne, B.L., Coombs, M., and Larsen, J., 2004, Preliminary geology of Gareloi volcano, Western Aleutian Islands (Alaska) [abs.]: Eos, Transactions, American Geophysical Union, v. 85, no. 47, Fall Meeting Supplement, Abstract V43E-1454.

Caplan-Auerbach, J., and Prejean, S.G., 2005, High levels of non-eruptive seismicity at Mount Gareloi Volcano, Alaska [abs.]: Eos, Transactions, American Geophysical Union, v. 86, no. 52, Fall Meeting Supplement, Abstract V33A-0673.

Miller, T.P., McGimsey, R.G., Richter, D.H., Riehle, J.R., Nye, C.J., Yount, M.E., and Dumoulin, J.A., 1998, Catalog of the historically active volcanoes of Alaska: U.S. Geological Survey Open-File Report 98-582, 104 p.

Reeder, J.W., 1990, Gareloi, in Annual report of the world volcanic eruptions in 1987, Bulletin of Volcanic Eruptions, no. 27, p. 37. [appears in Bulletin of Volcanology, v. 52, 80-page supplement, October 1990]

Smithsonian Institution, 1987, Gareloi: Scientific Event Alert Network (SEAN) Bulletin, v. 12 , no. 8 .

\section{Comprehensive References}

\section{Eruptions}

Miller, T.P., McGimsey, R.G., Richter, D.H., Riehle, J.R., Nye, C.J., Yount, M.E., and Dumoulin, J.A., 1998, Catalog of the historically active volcanoes of Alaska: U.S. Geological Survey Open-File Report 98-582, 104 p. 
Reeder, J.W., 1992, Gareloi, in Annual report of the world volcanic eruptions in 1989, Bulletin of Volcanic Eruptions, no. 29, p. 70. [appears in Bulletin of Volcanology, v. 54, 101-page supplement, January 1992]

\section{Tanaga}

Comprehensive References

1101-08-

\section{Unrest}

Coombs, M.L., McGimsey, R.G., and Browne, B.L., 2007, Preliminary volcano-hazard assessment for the Tanaga volcanic cluster, Tanaga Island, Alaska: U.S. Geological Survey Scientific Investigations Report 2007-5094, 33 p.

Dixon, J.P., Stihler, S.D., Power, J.A., Tytgat, G., Estes, S., and McNutt, S.R., 2006, Catalog of earthquake hypocenters at Alaskan volcanoes - January 1 through December 31, 2005: U.S. Geological Survey Open-File Report 2006-1264, p. 78.

McGimsey, R.G., Neal, C.A., Dixon, J.P., and Ushakov, S., 2007, 2005 Volcanic activity in Alaska, Kamchatka, and the Kurile Islands-Summary of events and response of the Alaska Volcano Observatory: U.S. Geological Survey Scientific Investigations Report 2007-5269, $94 \mathrm{p}$.

Smithsonian Institution, 2006, Tanaga: Bulletin of the Global Volcanism Network, v. 31, no. 1.

\section{Kanaga Volcano}

1101-11-

Comprehensive References

1994-1995 Eruption

McGimsey, R.G., and Neal, C.A., 1996, 1995 volcanic activity in Alaska-Summary of events and response of the Alaska Volcano Observatory: U.S. Geological Survey Open-File Report 96-738, 25 p.

Miller, T.P., McGimsey, R.G., Richter, D.H., Riehle, J.R., Nye, C.J., Yount, M.E., and Dumoulin, J.A., 1998, Catalog of the historically active volcanoes of Alaska: U.S. Geological Survey Open-File Report 98-582, 104 p.

Neal, C.A., Doukas, M.P., and McGimsey, R.G., 1995, Volcanic activity in AlaskaSummary of events and response of the Alaska Volcano Observatory 1994: U.S. Geological Survey Open-File Report 95-271, 20 p. 
Neal, C.A., McGimsey, R.G., and Doukas, M.P., 1996, Volcanic activity in AlaskaSummary of events and response of the Alaska Volcano Observatory 1993: U.S. Geological Survey Open-File Report 96-24, 21 p.

Smithsonian Institution, 1993, Kanaga: Global Volcanism Network Bulletin, v. 18, no. 12.

Smithsonian Institution, 1994, Kanaga: Global Volcanism Network Bulletin, v. 19, nos. $1,2,3,4,5,6,7,9$ and 11 .

Smithsonian Institution, 1995, Kanaga: Global Volcanism Network Bulletin, v. 20, nos. 4,6 and 8.

Waythomas, C.F., Miller, T.P., and Nye, C.J., 2001, Geology and late Quaternary eruptive history of Kanaga volcano, a calc-alkaline stratovolcano in the western Aleutian Islands, Alaska: U.S. Geological Survey Professional Paper 1678, 18 p.

Waythomas, C.F., Miller, T.P., and Nye, C.J., 2002, Preliminary volcano-hazard assessment for Kanaga Volcano, Alaska: U.S. Geological Survey Open-File Report 02-397, 34 p.

\title{
Kasatochi Volcano
}

\author{
1101-11-
}

Selected References

\section{Eruption}

Arnoult, K.M., Jr., Olson, J.V., Szuberla, C.A., Garcés, M., Fee, D., McNutt, S.R., and Hedlin, M.A., 2008, Infrasound observations of the recent explosive eruptions of Okmok and Kasatochi volcanoes, Alaska [abs.]: Eos, Transactions, American Geophysical Union, v. 89, no. 53, Fall Meeting Supplement, Abstract A53B0262.

Buchheit, R.M., and Ford, J.C., 2008, Biological monitoring in the central Aleutian Islands, Alaska in 2008-Summary appendices: U.S. Fish and Wildlife Service Report AMNWR 08/12, Homer, AK, 141 p.

Dean, K., Webley, P.W., Lovick, J., Puchrik, R., Bailey, J.E., Dehn, J., and Valcic, L., 2008, Alaska Volcano Observatory's satellite remote sensing of the Okmok and Kasatochi 2008 eruptions [abs.]: Eos, Transactions, American Geophysical Union, v. 89, no. 53, Fall Meeting Supplement, Abstract A53B-0265.

Izbekov, P.E., 2008, Petrology of the 2008 eruption of Kasatochi volcano, Alaska [abs.]: Eos, Transactions, American Geophysical Union, v. 89, no. 53, Fall Meeting Supplement, Abstract A53B-0264. 
Ruppert, N.A., Hansen, R.A., West, M., Prejean, S., 2008, Seismic swarm associated with the 2008 eruption of Kasatochi volcano, Alaska [abs]: Eos, Transactions, American Geophysical Union, v. 89, no. 53, Fall Meeting Supplement, Abstract A53B-0261.

Smithsonian Institution, 2008, Kasatochi, Bulletin of the Global Volcanism Network, v. 33 , no. 7.

Yang, K., Krotkov, N.A., Krueger, A.J., Carn, S.A., and Bhartia, P.K., 2008, OMI Measurements of sulfur dioxide abundances and altitudes of the volcanic plumes from eruptions of Okmok and Kasatochi in 2008 [abs.]: Eos, Transactions, American Geophysical Union, v. 89, no. 53, Fall Meeting Supplement, Abstract A53B-0269.

\title{
Korovin/Atka Volcano
}

\author{
1101-16-
}

Comprehensive References

\section{Eruption}

Miller, T.P., McGimsey, R.G., Richter, D.H., Riehle, J.R., Nye, C.J., Yount, M.E., and Dumoulin, J.A., 1998, Catalog of the historically active volcanoes of Alaska: U.S. Geological Survey Open-File Report 98-582, 104 p.

Reeder, J.W., 1990, Kliuchef, in Annual report of the world volcanic eruptions in 1987: Bulletin of Volcanic Eruptions, v. 27, p. 39-40. [appears in Bulletin of Volcanology, v. 52, 80-page supplement, October 1990]

Reeder, J.W., 1990, Korovin, in Annual report of the world volcanic eruptions in 1987: Bulletin of Volcanic Eruptions, v. 27, p. 38-39. [appears in Bulletin of Volcanology, v. 52, 80-page supplement, October 1990]

Smithsonian Institution, 1987, Atka: Scientific Event Alert Network (SEAN) Bulletin v. 12 , no. 3 .

\section{Comprehensive References}

\section{Eruption}

McGimsey, R.G., Neal, C.A., and Girina, O., 2003, 1998 volcanic activity in Alaska and Kamchatka-Summary of events and response of the Alaska Volcano Observatory: U.S. Geological Survey Open-File Report 03-423, 38 p.

Smithsonian Institution, 1998, Atka, Bulletin of the Global Volcanism Network, v. 23, no. 6. 
Comprehensive References

2005 Unrest

Dixon, J.P., Stihler, S.D., Power, J.A., Tytgat, G., Estes, S., and McNutt, S.R., 2006, Catalog of earthquake hypocenters at Alaskan volcanoes-January 1 through December 31, 2005: U.S. Geological Survey Open-File Report 2006-1264, 78 p., available at http://pubs.usgs.gov/of/2006/1264/

McGimsey, R.G., Neal, C.A., Dixon, J.P., and Ushakov, S., 2007, 2005 Volcanic activity in Alaska, Kamchatka, and the Kurile Islands-Summary of events and response of the Alaska Volcano Observatory: U.S. Geological Survey Scientific Investigations Report 2007-5269, 94 p.

Comprehensive References

$\underline{2006}$ Eruption

Dixon, J.P., Stihler, S.D., Power, J.A., and Searcy, C., 2008, Catalog of earthquake hypocenters at Alaskan volcanoes-January 1 through December 31, 2006: U.S. Geological Survey Data Series 326, 79 p.

Smithsonian Institution, 2006, Atka: Bulletin of the Global Volcanism Network, v. 31, nos. 2 and 11.

\section{Seguam}

Comprehensive References

1101-18-

\section{Eruption}

Doukas, M.P., McGimsey, R.G., and Dorava, J.M., 1995, A video of 10 years of volcanic activity in Alaska-1983 to 1992 [abs.]: Geological Society of America, Abstracts with Programs, v. 27, no. 5, p. 15.

Jicha, B.R., and Singer, B.S., 2006, Volcanic history and magmatic evolution of Seguam Island, Aleutian Island arc, Alaska: Geological Society of America Bulletin, v. 118 , no. $7 / 8$, p. $805-822$.

Masterlark, T., and Lu, Z., 2002, Tomography of coupled poroelastic and magmaintrusion deformation sources, revealed by InSAR - Application to Seguam Volcano [abs.]: Eos, Transactions, American Geophysical Union, v. 83, no. 47, Fall Meeting Supplement, Abstract G51A-0950.

McGimsey, R.G., 1995, Seguam, in Annual report of the world volcanic eruptions in 1992: Bulletin of Volcanic Eruptions, no. 32, p. 87. [appears in Bulletin of Volcanology, v. 57, 99-page supplement, March 1995] 
McGimsey, R.G., and Miller, T.P., 1995, Quick reference to Alaska's active volcanoes and listing of historical eruptions, 1760-1994: U.S. Geological Survey Open-File Report OF 95-0520, $13 \mathrm{p}$.

Miller, T.P., McGimsey, R.G., Richter, D.H., Riehle, J.R., Nye, C.J., Yount, M.E., and Dumoulin, J.A., 1998, Catalog of the historically active volcanoes of Alaska: U.S. Geological Survey Open-File Report 98-582, 104 p.

Neal, C.A., McGimsey, R.G., and Doukas, M.P., 1995, 1992 volcanic activity in Alaska-Summary of events and response of the Alaska Volcano Observatory: U.S. Geological Survey Open-File Report 95-83, 26 p.

Price, E.J., 2004, Dynamic deformation of Seguam Island, Aleutian Islands, Alaska, 1993-2000-Implications for magmatic and hydrothermal processes: Journal of Geophysical Research, v. 109, B04202, doi:10.1029/2003JB002671, 19 p.

Smithsonian Institution, 1992, Seguam: Bulletin of the Global Volcanism Network v. 17, no. 12 .

\section{Comprehensive References}

\section{Eruption}

Jicha, B.R., and Singer, B.S., 2006, Volcanic history and magmatic evolution of Seguam Island, Aleutian Island arc, Alaska: Geological Society of America Bulletin, v. 118, no. $7 / 8$, p. $805-822$.

McGimsey, R.G., and Miller, T.P., 1995, Quick reference to Alaska's active volcanoes and listing of historical eruptions, 1760-1994: U.S. Geological Survey Open-File Report 95-0520, 13 p.

Miller, T.P., McGimsey, R.G., Richter, D.H., Riehle, J.R., Nye, C.J., Yount, M.E., and Dumoulin, J.A., 1998, Catalog of the historically active volcanoes of Alaska: U.S. Geological Survey Open-File Report 98-582, 104 p.

Neal, C.A., 1996, Seguam, in Annual report of the world volcanic eruptions in 1993: Bulletin of Volcanic Eruptions, no. 33, p. 90-91. [appears in Bulletin of Volcanology, v. 58, 132-page supplement, March 1996]

Neal, C.A., McGimsey, R.G., and Doukas, M.P., 1996, Volcanic activity in AlaskaSummary of events and response of the Alaska Volcano Observatory 1993: U.S. Geological Survey Open-File Report 96-24, 21 p.

Price, E.J., 2004, Dynamic deformation of Seguam Island, Aleutian Islands, Alaska, 1993-2000 - Implications for magmatic and hydrothermal processes: Journal of Geophysical Research, v. 109, B04202, doi:10.1029/2003JB002671, 19 p. 
Smithsonian Institution, 1993, Seguam: Bulletin of the Global Volcanism Network v. 18, nos., 5,7 , and 8 .

\section{Amukta}

1101-19-

Comprehensive References

1987 Eruption

Miller, T.P., McGimsey, R.G., Richter, D.H., Riehle, J.R., Nye, C.J., Yount, M.E., and Dumoulin, J.A., 1998, Catalog of the historically active volcanoes of Alaska: U.S. Geological Survey Open-File Report 98-582, 104 p.

Reeder, J.W., 1990, Amukta, in Annual report of the world volcanic eruptions in 1987: Bulletin of Volcanic Eruptions, no. 27, p. 40. [appears in Bulletin of Volcanology, v. 52, 91-page supplement, March 1990]

Smithsonian Institution, 1987, Amukta: Scientific Event Alert Network (SEAN) Bulletin, v. 12 , no. 8 .

Comprehensive References

1996 Eruption

Neal, C.A., and McGimsey, R.G., 1997, 1996 volcanic activity in Alaska and Kamchatka-Summary of events and response of the Alaska Volcano Observatory: U.S. Geological Survey Open-File Report 97-433, 33 p.

McGimsey, R.G., and Wallace, K.L., 1999, 1997 volcanic activity in Alaska and Kamchatka - Summary of events and response of the Alaska Volcano Observatory: U.S. Geological Survey Open-File Report 99-448, 41 p.

Miller, T.P., McGimsey, R.G., Richter, D.H., Riehle, J.R., Nye, C.J., Yount, M.E., and Dumoulin, J.A., 1998, Catalog of the historically active volcanoes of Alaska: U.S. Geological Survey Open-File Report 98-582, 104 p.

Smithsonian Institution, 1996, Amukta: Global Volcanism Network Bulletin, v. 21, no. 9.

\section{Cleveland}

1101-24-

Comprehensive References

\section{$\underline{1984 \text { Eruption }}$}

Reeder, J.W., 1987, Cleveland, in Annual report of the world volcanic eruptions in 1984, Bulletin of Volcanic Eruptions, no. 24, p. 37-38. [appears in Bulletin of Volcanology, v. 49, 71-page supplement, March 1987] 
Comprehensive References

1986 Eruption

Miller, T.P., McGimsey, R.G., Richter, D.H., Riehle, J.R., Nye, C.J., Yount, M.E., and Dumoulin, J.A., 1998, Catalog of the historically active volcanoes of Alaska: U.S. Geological Survey Open-File Report 98-582, 104 p.

Reeder, J.W., 1989, Cleveland, in Annual report of the world volcanic eruptions in 1986: Bulletin of Volcanic Eruptions, no. 26, p. 45-47. [appears in Bulletin of Volcanology, v. 51, 73-page supplement, January 198]

Smithsonian Institution, 1986, Cleveland: Scientific Event Alert Network (SEAN) Bulletin, v. 11, nos. 4 and 6.

Comprehensive References

$\underline{1987 \text { Eruption }}$

Miller, T.P., McGimsey, R.G., Richter, D.H., Riehle, J.R., Nye, C.J., Yount, M.E., and Dumoulin, J.A., 1998, Catalog of the historically active volcanoes of Alaska: U.S. Geological Survey Open-File Report 98-582, 104 p.

Reeder, J.W., 1990, Cleveland, in Annual report of the world volcanic eruptions in 1987: Bulletin of Volcanic Eruptions, no. 27, p. 41-44. [appears in Bulletin of Volcanology, v. 52, 91-page supplement, March 1990]

Smithsonian Institution, 1987, Cleveland: Scientific Event Alert Network (SEAN) Bulletin, v. 12, nos. 6-8.

Comprehensive References

1994 Eruption

Neal, C.A., Doukas, M.P., and McGimsey, R.G., 1995, Volcanic activity in Alaska and Kamchatka-Summary of events and response of the Alaska Volcano Observatory 1994: U.S. Geological Survey Open-File Report 95-271, 20 p.

Nicolaysen, K.P., Bridges, D., and Swapp, S., 2005, Crustal control on crystallization depths? Preliminary evidence from Mt. Cleveland, Chuginadak Island, Eastern Aleutian arc [abs.]: Eos, Transactions, American Geophysical Union, v. 86, no. 52, Fall Meeting Supplement, Abstract V21D-0655.

Miller, T.P., McGimsey, R.G., Richter, D.H., Riehle, J.R., Nye, C.J., Yount, M.E., and Dumoulin, J.A., 1998, Catalog of the historically active volcanoes of Alaska: U.S. Geological Survey Open-File Report 98-582, 104 p. 
Smithsonian Institution, 1994, Cleveland: Bulletin of the Global Volcanism Network, v. 19 , nos. 5 and 6.

\section{Comprehensive References}

1997 Eruption

McGimsey, R.G., and Wallace, K., 1999, 1997 volcanic activity in Alaska and Kamchatka-Summary of events and response of the Alaska Volcano Observatory: U.S. Geological Survey Open-File Report 99-448, 42 p.

Selected References

\section{Eruption}

Dean, K.G., Dehn, J., Papp, K.R., Smith, S., Izbekov, P., Peterson, R., Kearney, C., and Steffke, A., 2004, Integrated satellite observations of the 2001 eruption of Mt. Cleveland, Alaska: Journal of Volcanology and Geothermal Research, v. 135, p. 51-73.

Gu, Y., Rose, W.I., Schneider, D.J., Bluth, G.J.S., and Watson, I.M., 2005, Advantageous GOES IR results for ash mapping at high latitudes-Cleveland eruptions 2001: Geophysical Research Letters, v. 32, L02305, doi:10.1029/2004GL021651, 5 p.

McGimsey, R.G., Neal, C.A., and Girina, O., 2004, 2001 volcanic activity in Alaska and Kamchatka-Summary of events and response of the Alaska Volcano Observatory: U.S. Geological Survey Open-File Report 2004-1453, 57 p.

Simpson, J.J., Hufford, G.L., Pieri, D., Servranckx, R., Berg, J.S., and Bauer, C., 2002, The February 2001 eruption of Mount Cleveland, Alaska - Case study of an aviation hazard: American Meteorological Society, v. 17, p. 691-704.

Smith, S.J., Dehn, J., and Moore, R.B., 2003, Analysis of volcanic deposits from the 2001 eruption of Mt. Cleveland, Alaska using multisensory satellite data and field observations [abs.]: Eos, Transactions, American Geophysical Union, v. 84, no. 46, Fall Meeting Supplement, Abstract V51F-0349.

Smithsonian Institution, 2001, Cleveland: Bulletin of the Global Volcanism Network, v. 26, nos. 1 and 4.

Watson, I.M., Realmuto, V.J., Rose, W.I., Prata, A.J., Bluth, G.J.S., Gu, Y., Bader, C.E., and $\mathrm{Yu}, \mathrm{T} ., 2004$, Thermal infrared remote sensing of volcanic emissions using the moderate resolution imaging spectroradiometer: Journal of Volcanology and Geothermal Research, v. 135, nos.1 and 2, p. 75-89. 


\section{Selected References}

\section{$\underline{2005}$ Eruption}

Bridges, D.L., and Nicolaysen, K.P., 2005, Eruption of alkaline basalts prior to the calcalkaline lavas of Mt. Cleveland volcano, Aleutian Arc, Alaska [abs.]: Eos, Transactions, American Geophysical Union, v. 86, no. 52, Fall Meeting Supplement, Abstract V31C-0636.

Dixon, J.P., Stihler, S.D., Power, J.A., Tytgat, G., Estes, S., and McNutt, S.R., 2006, Catalog of earthquake hypocenters at Alaskan volcanoes-January 1 through December 31, 2005: U.S. Geological Survey Open-File Report 2006-1264, 78 p.

McGimsey, R.G., Neal, C.A., Dixon, J.P., and Ushakov, S., 2007, 2005 volcanic activity in Alaska, Kamchatka, and the Kurile Islands-Summary of events and response of the Alaska Volcano Observatory: U.S. Geological Survey Scientific Investigations Report 2007-5269, 106 p.

Smithsonian Institution, 2005, Cleveland: Bulletin of the Global Volcanism Network, v. 30, no. 9 .

Comprehensive References

$\underline{2006}$ Eruption

Smithsonian Institution, 2006, Cleveland: Bulletin of the Global Volcanism Network, v. 31 , nos. $1,6,7$, and 9 .

Comprehensive References

2007-2008 Eruption

Cervelli, P.F., and Cameron, C.E., 2008, Causation or coincidence? The correlations in time and space of the 2008 eruptions of Cleveland, Kasatochi, and Okmok Volcanoes, Alaska [abs.]: Eos, Transactions, American Geophysical Union, v. 89, no. 53, Fall Meeting Supplement, Abstract A53B-0278.

Smithsonian Institution, 2008, Cleveland: Bulletin of the Global Volcanism Network, v. 33 , nos. 2 and 7.

\section{Okmok}

1101-29-

Comprehensive References

\section{Eruption}

Miller, T.P., McGimsey, R.G., Richter, D.H., Riehle, J.R., Nye, C.J., Yount, M.E., and Dumoulin, J.A., 1998, Catalog of the historically active volcanoes of Alaska: U.S. Geological Survey Open-File Report 98-0582, 104 p. 
Reeder, J.W., 1987, Okmok, in Annual report of the world volcanic eruptions in 1984:

Bulletin of Volcanic Eruptions, no. 24, p. 55-56. [appears in Bulletin of

Volcanology, v. 49, 71-page supplement, March 1987]

Comprehensive References

1983 Eruption

Miller, T.P., McGimsey, R.G., Richter, D.H., Riehle, J.R., Nye, C.J., Yount, M.E., and Dumoulin, J.A., 1998, Catalog of the historically active volcanoes of Alaska: U.S. Geological Survey Open-File Report 98-0582, 104 p.

Reeder, J.W., 1986, Okmok, in Annual report of the world volcanic eruptions in 1983:

Bulletin of Volcanic Eruptions, no. 23, p. 35-36 and 52-53. [appears in Bulletin of Volcanology, v. 48, 44-page supplement, January 1986]

Smithsonian Institution, 1983, Okmok: Scientific Event Alert Network (SEAN) Bulletin, v. 8 , no. 8 .

\section{Comprehensive References}

\section{6-1988 Eruption}

Miller, T.P., McGimsey, R.G., Richter, D.H., Riehle, J.R., Nye, C.J., Yount, M.E., and Dumoulin, J.A., 1998, Catalog of the historically active volcanoes of Alaska: U.S. Geological Survey Open-File Report 98-0582, 104 p.

Reeder, J.W., 1989, Okmok, in Annual report of the world volcanic eruptions in 1986: Bulletin of Volcanic Eruptions, no. 26, p. 47-48. [appears in Bulletin of Volcanology, v. 51, 73-page supplement, January 1989]

Reeder, J.W., 1990, Okmok, in Annual report of the world volcanic eruptions in 1987: Bulletin of Volcanic Eruptions, no. 27, p. 44-46. [appears in Bulletin of Volcanology, v. 52, 91-page supplement, March 1990]

Reeder, J.W., 1991, Okmok, in Annual report of the world volcanic eruptions in 1988: Bulletin of Volcanic Eruptions, no. 28, p. 58-60. [appears in Bulletin of Volcanology, v. 53, 108-page supplement, March 1991]

Smithsonian Institution, 1986, Okmok: Scientific Event Alert Network (SEAN) Bulletin, v. 11 , no. 12 .

Smithsonian Institution, 1987, Okmok: Scientific Event Alert Network (SEAN) Bulletin, v. 12 , nos. $1,3,6,7,11$ and 12 .

Smithsonian Institution, 1988, Okmok: Scientific Event Alert Network (SEAN) Bulletin, v. 13 , no. 2 . 


\section{Selected References}

\section{Eruption}

Lu, Z., Fielding, E., Patrick, M.R., and Trautwein, C.M., 2003, Estimating lava volume by precision combination of multiple baseline spaceborne and airborne interferometric synthetic aperture radar-The 1997 eruption of Okmok volcano, Alaska: IEEE transactions on Geoscience and Remote Sensing, v. 41, p. 14281436.

Lu, Z., Mann, D., Freymueller, J.T., and Meyer, D.J., 2000, Synthetic aperture radar interferometry of Okmok volcano, Alaska-Radar observations: Journal of Geophysical Research, v. 105, no. B5, p. 10791-10806.

Lu, Z., Masterlark, T., and Dzurisin, D., 2005, Interferometric synthetic aperture radar study of Okmok volcano, Alaska, 1992-2003-Magma supply dynamics and postemplacement lava flow deformation: Journal of Geophysical Research, v. 110, doi:10.1029/2004JB003148, 18 p.

Mann, D., Freymueller, J., and Lu, Z., 2002, Deformation associated with the 1997 eruption of Okmok volcano, Alaska: Journal of Geophysical Research, v. 107, no. B4, p. 2072-2089.

McGimsey, R.G., and Wallace, K., 1999, 1997 volcanic activity in Alaska and Kamchatka-Summary of events and response of the Alaska Volcano Observatory: U.S. Geological Survey Open-File Report 99-448, 42 p.

Miller, T.P., McGimsey, R.G., Richter, D.H., Riehle, J.R., Nye, C.J., Yount, M.E., and Dumoulin, J.A., 1998, Catalog of the historically active volcanoes of Alaska: U.S. Geological Survey Open-File Report 98-0582, 104 p.

Miyagi, Y., Freymueller, J., Kimata, F., Sato, T., and Mann, D., 2006, Rapid inflation caused by shallow magmatic activities at Okmok volcano, Alaska, detected by GPS campaigns 2000-2003 [abs.]: Eos, Transactions, American Geophysical Union, v. 87, no. 52, Fall Meeting Supplement, Abstract G53A-0865.

Moxey, L., Dehn, J., Papp, K., Patrick, M., and Guritz, R., 2001, The 1997 eruption of Okmok volcano, Alaska, a synthesis of remotely sensed data [abs.]: Eos, Transactions, American Geophysical Union, v. 82, no. 47, Fall Meeting Supplement, Abstract V42C-1033.

Patrick, M.R., Dehn, J., Papp, K.R., Lu, Z., Dean, K., Moxey, L., Izbekov, P., and Guritz, R., 2003, The 1997 eruption of Okmok volcano, Alaska-A synthesis of remotely sensed imagery: Journal of Volcanology and Geothermal Research, v. 127, p. 87105. 


\section{Selected References}

\section{$\underline{2008 \text { Eruption }}$}

Corradini, S., Merucci, L., and Prata, F., 2008, Volcanic ash and $\mathrm{SO}_{2}$ in the Kasatochi and Okmok eruptions - Interference and impact on quantitative retrievals [abs.]: Eos, Transactions, American Geophysical Union, v. 89, no. 53, Fall Meeting Supplement, Abstract A53B-0268.

Dean, K., Webley, P.W., Lovick, J., Puchrik, R., Bailey, J.E., Dehn, J., and Valcic, L., 2008, Alaska Volcano Observatory's satellite remote sensing of the Okmok and Kasatochi 2008 eruptions [abs.]: Eos, Transactions, American Geophysical Union, v. 89, no. 53, Fall Meeting Supplement, Abstract A53B-0265.

Haney, M.M., Fournier, T., and Searcy, C., 2008, Seismic estimates of the depth of the magma chamber and low-frequency tremor during the 2008 eruption of Okmok Volcano, Alaska [abs.]: Eos, Transactions, American Geophysical Union, v. 89, no. 53, Fall Meeting Supplement, Abstract A51J-04.

Larsen, J.F., Neal, C.A., and Schaefer, J.R., 2008, Preliminary overview of the geology, petrology, and geochemistry of the July-August 2008 eruption of Okmok Volcano, Alaska [abs.]: Eos, Transactions, American Geophysical Union, v. 89, no. 53, Fall Meeting Supplement, Abstract A51J-03.

Lu, Z., Dzurisin, D., and Rykhus, R., 2008, InSAR monitoring of the 2008 eruption at Okmok volcano, Alaska [abs.]: Eos, Transactions, American Geophysical Union, v. 89, no. 53, Fall Meeting Supplement, Abstract A1J-05.

Yang, K., Krotkov, N.A., Krueger, A.J., Carn, S.A., and Bhartia, P.K., 2008, OMI measurements of sulfur dioxide abundances and altitudes of the volcanic plumes from eruptions of Okmok and Kasatochi in 2008 [abs.]: Eos, Transactions, American Geophysical Union, v. 89, no. 53, Fall Meeting Supplement, Abstract A53B-0269.

\section{Comprehensive References}

\section{Bogoslof}

1101-30-

\section{Eruption}

Harbin, M.L., 1994, Observations of the 1992 lava dome, Bogoslof Island, eastern Aleutian Arc, Alaska [abs.]: Eos, Transactions, American Geophysical Union, v. 75, no. 44, p. 737.

McGimsey, R.G., Neal, C.A., and Doukas, M.P., 1995, 1992 volcanic activity in Alaska-Summary of events and response of the Alaska Volcano Observatory: U.S. Geological Survey Open-File Report 95-83, 26 p. 
Miller, T.P., McGimsey, R.G., Richter, D.H., Riehle, J.R., Nye, C.J., Yount, M.E., and Dumoulin, J.A., 1998, Catalog of the historically active volcanoes of Alaska: U.S. Geological Survey Open-File Report 98-0582, 104 p.

Shaishnikoff, L., Reeder, J.W., and Mowatt, T.C., 1992, The dome-forming July 1992 eruption of Bogoslof Island, Alaska [abs.]: Eos, Transactions, American Geophysical Union, v. 73, no. 43, p. 636.

Smithsonian Institution, 1992, Bogoslof: Bulletin of the Global Volcanism Network, v. 17 , nos. 6 and 7.

\section{Makushin}

1101-31-

Selected References

1980 Eruption

Arce, G.N., and Economides, M.J., 1982, Analysis of volcanic hazards from Makushin Volcano, Unalaska Island: New Zealand Geothermal Workshop, 4, Proceedings, p. 93-99.

Miller, T.P., McGimsey, R.G., Richter, D.H., Riehle, J.R., Nye, C.J., Yount, M.E., and Dumoulin, J.A., 1998, Catalog of the historically active volcanoes of Alaska: U.S. Geological Survey Open-File Report 98-0582, 104 p.

Reeder, J.W., 1982, Hydrothermal resources of the northern part of Unalaska Island, Alaska: Alaska Department of Natural Resources Open-File Report 163, 20 p.

Shackelford, D.C., 1982, Makushin, in Annual report of the world volcanic eruptions in 1980: Bulletin of Volcanic Eruptions, no. 20, p. 68. [appears in Bulletin of Volcanology, v. 45, 101-page supplement, December 1982]

Smithsonian Institution, 1980, Makushin: Scientific Event Alert Network (SEAN) Bulletin, v. 5, no. 7.

Selected References

\section{Eruption}

Beget, J.E., Nye, C.J., and Bean, K.W., 2000, Preliminary volcano-hazard assessment for Makushin Volcano, Alaska: Alaska Department of Natural Resources Report of Investigation 2000-4, 26 p.

Lu, Z., Power, J.A., McConnell, V.S., Wicks, C., Jr., and Dzurisin, D., 2001, Preeruptive inflation and surface interferometric coherence characteristics revealed by satellite 
radar interferometry at Makushin Volcano, Alaska-1993-2000: Journal of Geophysical Research, v. 107, 2266, doi:10.1029/2001JB000970, 13 p.

McGimsey, R.B., and Neal, C.A., 1996, 1995 volcanic activity in Alaska and Kamchatka-Summary of events and response of the Alaska Volcano Observatory: U.S. Geological Survey Open-File Report 96-738, 23 p.

Miller, T.P., McGimsey, R.G., Richter, D.H., Riehle, J.R., Nye, C.J., Yount, M.E., and Dumoulin, J.A., 1998, Catalog of the historically active volcanoes of Alaska: U.S. Geological Survey Open-File Report 98-0582, 104 p.

Smithsonian Institution, 1995, Makushin: Bulletin of the Global Volcanism Network, v. 20, no. 1 .

\section{Selected References}

\section{0-2001 Unrest}

Bridges, D.L., and Gao, S.S., 2006, Spatial variation of seismic $b$-values beneath Makushin volcano, Unalaska Island, Alaska: Earth and Planetary Science Letters, v. 245 , p. $408-415$.

Dixon, J.P., Stihler, S.D., Power, J.A., Tytgat, G., Estes, S., Moran, S.C., Paskievitch, J., and McNutt, S.R., 2002, Catalog of earthquake hypocenters at Alaskan volcanoes-January 1, 2000 through December 31, 2001: U.S. Geological Survey Open-File Report 02-0342, 56 p.

Lu, Z., Power, J.A., McConnell, V.S., Wicks, W.C., Jr., and Dzurisin, D., 2001, Preeruptive inflation and surface interferometric coherence characteristics revealed by satellite radar interferometry at Makushin Volcano, Alaska-19932000: Journal of Geophysical Research, v. 107, 2266, doi:10.1029/2001JB000970, $13 \mathrm{p}$.

McGimsey, R.G., Neal, C.A., and Girina, O., 2004: 2001 volcanic activity in Alaska and Kamchatka-Summary of events and response of the Alaska Volcano Observatory: U.S. Geological Survey Open-File Report 2004-1453, 53 p.

Smithsonian Institution, 1995, Makushin: Bulletin of the Global Volcanism Network, v. 26, no. 6 . 


\section{Akutan}

1101-32-

\section{Comprehensive References}

\section{Eruption}

Miller, T.P., McGimsey, R.G., Richter, D.H., Riehle, J.R., Nye, C.J., Yount, M.E., and Dumoulin, J.A., 1998, Catalog of the historically active volcanoes of Alaska: U.S. Geological Survey Open-File Report OF 98-0582, 104 p.

Shackelford, D.C., 1982, Akutan, in Annual report of the world volcanic eruptions in 1980: Bulletin of Volcanic Eruptions, no. 20, p. 69. [appears in Bulletin of Volcanology, v. 45, 101-page supplement, December 1982]

Smithsonian Institution, 1980, Akutan: Scientific Event Alert Network (SEAN) Bulletin, v. 5 , no. 9 .

\section{Comprehensive References}

\section{2-1983 Eruption}

Reeder, J.W., 1986, Akutan, in Annual report of the world volcanic eruptions in 1983: Bulletin of Volcanic Eruptions, no. 23, p. 37, 53-54. [appears in Bulletin of Volcanology, v. 48, 63-page supplement, March 1986]

Waythomas, C.F., 1998, Late Holocene caldera formation and stratigraphic framework of Holocene volcaniclastic deposits, Akutan Volcano, East-Central Aleutian Islands, Alaska [abs.]: Eos, Transactions, American Geophysical Union, Fall Meeting Supplement, Abstract V72C-16.

Waythomas, C.F., 1999, Stratigraphic framework of Holocene volcaniclastic deposits, Akutan Volcano, east-central Aleutian Islands, Alaska: Bulletin of Volcanology, v. 61 , no. 3 , p. 141-161.

Comprehensive References

\section{$\underline{1986 \text { Eruption }}$}

Miller, T.P., 1987a, Three volcanoes erupt in Alaska: Earthquakes and Volcanoes, v. 19, no. 6, p. 192-198.

Miller, T.P., 1987b, Three volcanoes erupt in Alaska, in Fiscal year 1986, U.S. Geological Survey Yearbook, p. 58-60.

Reeder, J.W., 1989, Akutan, in Annual report of the world volcanic eruptions in 1986: Bulletin of Volcanic Eruptions, no. 26, p. 49-51. [appears in Bulletin of Volcanology, v. 51, 73-page supplement, March 1989] 
Smithsonian Institution, 1986, Akutan: Scientific Event Alert Network (SEAN) Bulletin v. 11 , nos. $4,5,8$ and 9 .

Comprehensive References

1987 Eruption

Miller, T.P., McGimsey, R.G., Richter, D.H., Riehle, J.R., Nye, C.J., Yount, M.E., and Dumoulin, J.A., 1998, Catalog of the historically active volcanoes of Alaska: U.S. Geological Survey Open-File Report 98-0582, 104 p.

Reeder, J.W., 1990, Akutan, in Annual report of the world volcanic eruptions in 1987: Bulletin of Volcanic Eruptions, no. 27, p. 48-50. [appears in Bulletin of Volcanology, v. 52, 80-page supplement, October 1990]

Smithsonian Institution, 1987, Akutan: Scientific Event Alert Network (SEAN) Bulletin v. 12, nos. 1, 2 and 6 .

Waythomas, C.F., 1998, Late Holocene caldera formation and stratigraphic framework of Holocene volcaniclastic deposits, Akutan Volcano, East-Central Aleutian Islands, Alaska [abs.]: Eos, Transactions, American Geophysical Union, Fall Meeting Supplement, Abstract V72C-16.

Waythomas, C.F., 1999, Stratigraphic framework of Holocene volcaniclastic deposits, Akutan Volcano, east-central Aleutian Islands, Alaska: Bulletin of Volcanology, v. 61 , no. 3, p. 141-161.

Comprehensive References

1988 Eruption

Miller, T.P., McGimsey, R.G., Richter, D.H., Riehle, J.R., Nye, C.J., Yount, M.E., and Dumoulin, J.A., 1998, Catalog of the historically active volcanoes of Alaska: U.S. Geological Survey Open-File Report OF 98-0582, 104 p.

Reeder, J.W., 1991, Akutan, in Annual report of the world volcanic eruptions in 1988: Bulletin of Volcanic Eruptions, no. 28, p. 60-66. [appears in Bulletin of Volcanology, v. 53, 108-page supplement, January 1991]

Smithsonian Institution, 1988, Akutan: Scientific Event Alert Network (SEAN) Bulletin, v. 13, nos. 4-7.

Comprehensive References

1989 Eruption

Miller, T.P., McGimsey, R.G., Richter, D.H., Riehle, J.R., Nye, C.J., Yount, M.E., and Dumoulin, J.A., 1998, Catalog of the historically active volcanoes of Alaska: U.S. Geological Survey Open-File Report 98-0582, 104 p. 
Reeder, J.W., 1992, Akutan, in Annual report of the world volcanic eruptions in 1989:

Bulletin of Volcanic Eruptions, no. 29, p. 71-72. [appears in Bulletin of

Volcanology, v. 54, 101-page supplement, January 1992]

Smithsonian Institution, 1989, Akutan: Scientific Event Alert Network (SEAN) Bulletin, v. 14 , no. 4 .

Waythomas, C.F., 1998, Late Holocene caldera formation and stratigraphic framework of Holocene volcaniclastic deposits, Akutan Volcano, East-Central Aleutian Islands, Alaska [abs.]: Eos, Transactions, American Geophysical Union, Fall Meeting Supplement, Abstract V72C-16.

Waythomas, C.F., 1999, Stratigraphic framework of Holocene volcaniclastic deposits, Akutan Volcano, east-central Aleutian Islands, Alaska: Bulletin of Volcanology, v. 61 , no. 3, p. 141-161.

\section{Comprehensive References}

\section{Eruptions}

Miller, T.P., McGimsey, R.G., Richter, D.H., Riehle, J.R., Nye, C.J., Yount, M.E., and Dumoulin, J.A., 1998, Catalog of the historically active volcanoes of Alaska: U.S. Geological Survey Open-File Report 98-0582, 104 p.

Reeder, J.W., 1993, Akutan, in Annual report of the world volcanic eruptions in 1990: Bulletin of Volcanic Eruptions, no. 30, p. 61-62. [appears in Bulletin of Volcanology, v. 55, 91-page supplement, March 1993]

Smithsonian Institution, 1990, Akutan: Global Volcanism Network Bulletin, v. 15, no. 9

Comprehensive References

1991 Eruption

McGimsey, G., 1993, Volcanic activity in Alaska-September 1991-September 1992: Earthquakes and Volcanoes, v. 24, no. 2, p. 60-73.

Miller, T.P., McGimsey, R.G., Richter, D.H., Riehle, J.R., Nye, C.J., Yount, M.E., and Dumoulin, J.A., 1998, Catalog of the historically active volcanoes of Alaska: U.S. Geological Survey Open-File Report 98-0582, 104 p.

Reeder, J.W., 1994, Akutan, in Annual report of the world volcanic eruptions in 1991: Bulletin of Volcanic Eruptions, no. 31, p. 81-83. [appears in Bulletin of Volcanology, v. 56, 117-page supplement, March 1994]

Smithsonian Institution, 1991, Akutan: Bulletin of the Global Volcanism Network, v. 16, no. 11 . 
Comprehensive References

1992 Eruption

McGimsey, G., 1993, Volcanic activity in Alaska-September 1991-September 1992:

Earthquakes and Volcanoes, v. 24, no. 2, p. 60-73.

McGimsey, R.G., 1995, Akutan, in Annual report of the world volcanic eruptions in 1992: Bulletin of Volcanic Eruptions, no. 32, p. 91-92. [appears in Bulletin of Volcanology, v. 57, 119-page supplement, March 1995]

Miller, T.P., McGimsey, R.G., Richter, D.H., Riehle, J.R., Nye, C.J., Yount, M.E., and Dumoulin, J.A., 1998, Catalog of the historically active volcanoes of Alaska: U.S. Geological Survey Open-File Report 98-0582, 104 p.

\section{Selected References}

\section{Eruptions}

McGimsey, R.G., Neal, C.A., and Doukas, M.P., 1995, 1992 volcanic activity in Alaska-Summary of events and response of the Alaska Volcano Observatory: U.S. Geological Survey Open-File Report 95-83, 26 p.

Miller, T.P., McGimsey, R.G., Richter, D.H., Riehle, J.R., Nye, C.J., Yount, M.E., and Dumoulin, J.A., 1998, Catalog of the historically active volcanoes of Alaska: U.S. Geological Survey Open-File Report 98-0582, 104 p.

Smithsonian Institution, 1992, Akutan: Bulletin of the Global Volcanism Network, v. 17, nos. 3-4 and 11.

Stelling, P.L., 1996, Recent eruptive products of Akutan Volcano, Akutan Island, Alaska [abs.]: Eos, Transactions, American Geophysical Union, v. 77, no. 46, p. 771.

Waythomas, C.F., 1999, Stratigraphic framework of Holocene volcaniclastic deposits, Akutan Volcano, east-central Aleutian Islands, Alaska: Bulletin of Volcanology, v. 61 , no. 3 , p. $141-161$.

\section{Selected References}

\section{Unrest}

Keith, T.E.C., Nye, C.J., Eichelberger, J.C., Miller, T.P., and Power, J.A., 1996, March 1996 seismic crisis at Akutan Volcano, central Aleutian Arc, Alaska [abs.]: Eos, Transactions, American Geophysical Union, v. 77, no. 46, p. 815.

Lu, Z., Wicks, C., Jr., Kwoun, O., Power, J.A., and Dzurisin, D., 2005, Surface deformation associated with the March 1996 earthquake swarm at Akutan Island, Alaska, revealed by C-band ERS and L-band JERS radar interferometry: Canadian Journal of Remote Sensing, v. 31, no. 1, p. 7-20. 
Lu, Z., Wicks, C., Jr., Power, J.A., and Dzurisin, D., 2000, Ground deformation associated with the March 1996 earthquake swarm at Akutan volcano, Alaska, revealed by satellite radar interferometry: Journal of Geophysical Research, v. 105 , no. B9, p. 21483-21495.

McNutt, S.R., and Marzocchi, W., 2004, Simultaneous earthquake swarms and eruption in Alaska, Fall 1996-Statistical significance and inference of a large aseismic slip event: Bulletin of the Seismological Society of America, v. 94, no. 5, p. 18311841.

Miller, T.P., McGimsey, R.G., Richter, D.H., Riehle, J.R., Nye, C.J., Yount, M.E., and Dumoulin, J.A., 1998, Catalog of the historically active volcanoes of Alaska: U.S. Geological Survey Open-File Report 98-0582, 104 p.

Neal, C.A., and McGimsey, R.G., 1997, 1996 volcanic activity in Alaska and Kamchatka-Summary of events and response of the Alaska Volcano Observatory: U.S. Geological Survey Open-File Report 97-433, 33 p.

Power, J.A., Paskievitch, J.F., Richter, D.H., McGimsey, R.G., Stelling, P L., Jolly, A.D., and Fletcher, H.J., 1996, 1996 seismicity and ground deformation at Akutan Volcano, Alaska [abs.]: Eos, Transactions, American Geophysical Union, v. 77, no. 46, p. 514.

Rykhus, R., Lu, Z., Wicks, C., Power, J., Dzurisin, D., and Masterlark, T., 2002, Surface deformation over Akutan Island, Alaska, during the 1996 seismic swarm, revealed by both C-band ERS and L-band JERS radar interferometry [abs.]: Eos, Transactions, American Geophysical Union, v. 83, no. 47, Fall Meeting Supplement, Abstract T12A-1292.

Waythomas, C.F., 1999, Stratigraphic framework of Holocene volcaniclastic deposits, Akutan Volcano, east-central Aleutian Islands, Alaska: Bulletin of Volcanology, v. 61, no. 3 , p. $141-161$.

\section{Westdahl}

1101-34-

Selected References

\section{1-1992 Eruption}

Dixon, J.P., Power, J.A., and Stihler, S.D., 2005, Seismic Observations of Westdahl volcano and Western Unimak Island Alaska-1999-2005 [abs.]: Eos, Transactions, American Geophysical Union, v. 86, p. 52, Fall Meeting Supplement, Abstract S11B-0169. 
Lu, Z., Masterlark, T., Dzurisin, D., Rykhus, R., and Wicks, C., Jr., 2003, Magma supply dynamics at Westdahl volcano, Alaska, modeled from satellite radar interferometry: Journal of Geophysical Research, v. 108, no. B7, 2354, doi:10.1029/2002JB002311, $22 \mathrm{p}$.

Lu, Z., Rykhus, R., Masterlark, T., and Dean, K.G., 2004, Mapping recent lava flows at Westdahl Volcano, Alaska, using radar and optical satellite imagery: Remote Sensing of the Environment, v. 91, p. 345-353.

McGimsey, G., 1993, Volcanic activity in Alaska-September 1991-September 1992: Earthquakes and Volcanoes, v. 24, no. 2, p. 60-73.

McGimsey, R.G., Neal, C.A., and Doukas, M.P., 1995, Volcanic activity in AlaskaSummary of events and response of the Alaska Volcano Observatory 1992: U.S. Geological Survey Open-File Report 95-83, 26 p.

Miller, T.P., McGimsey, R.G., Richter, D.H., Riehle, J.R., Nye, C.J., Yount, M.E., and Dumoulin, J.A., 1998, Catalog of the historically active volcanoes of Alaska: U.S. Geological Survey Open-File Report 98-0582, 104 p.

Mouginis-Mark, P.J., Rowland, S.K., and Smith, G.A., 1992, ERS-1 radar data for Aleutian and Alaskan volcanoes [abs.]: Eos, Transactions, American Geophysical Union, v. 73, no. 43, p. 613-614.

Reeder, J.W., and Doukas, M., 1994, Westdahl, in Annual report of the world volcanic eruptions in 1991: Bulletin of Volcanic Eruptions, no. 31, p. 83-86. [appears in Bulletin of Volcanology, v. 56, 117-page supplement, March 1994]

Smithsonian Institution, 1991a, Westdahl: Scientific Event Alert Network (SEAN) Bulletin, v. 16, no. 11.

Smithsonian Institution, 1991b, Westdahl: Bulletin of the Global Volcanism Network, v. 16, no. 12.

Smithsonian Institution, 1992, Westdahl: Bulletin of the Global Volcanism Network, v. 17 , no. 1.

\section{Comprehensive References}

\section{6-1987 Eruption}

\section{Shishaldin}

1101-36-

Miller, T.P., McGimsey, R.G., Richter, D.H., Riehle, J.R., Nye, C.J., Yount, M.E., and Dumoulin, J.A., 1998, Catalog of the historically active volcanoes of Alaska: U.S. Geological Survey Open-File Report 98-0582, 104 p. 
Reeder, J.W., 1989, Shishaldin, in Annual report of the world volcanic eruptions in 1986:

Bulletin of Volcanic Eruptions, no. 26, p. 51-53. [appears in Bulletin of

Volcanology, v. 51, 73-page supplement, March 1989]

Reeder, J.W., 1990, Shishaldin, in Annual report of the world volcanic eruptions in 1987: Bulletin of Volcanic Eruptions, no. 27, p. 50-51. [appears in Bulletin of Volcanology, v. 52, 80-page supplement, October 1990]

Smithsonian Institution, 1986, Shishaldin: Scientific Event Alert Network (SEAN)

Bulletin, v. 11, nos. 4, 5, 8, 9 and 12.

Smithsonian Institution, 1987, Shishaldin: Scientific Event Alert Network (SEAN)

Bulletin, v. 12, no. 2.

Comprehensive References

1995-1996 Eruption

McGimsey, R.G., and Neal, C.A., 1996, volcanic activity in Alaska and KamchatkaSummary of events and response of the Alaska Volcano Observatory 1995: U.S. Geological Survey Open-File Report 96-734, 25 p.

McGimsey, R.G., and Wallace, K., 1999, 1997 volcanic activity in Alaska and Kamchatka-Summary of events and response of the Alaska Volcano Observatory: U.S. Geological Survey Open-File Report 99-448, 42 p.

Miller, T.P., McGimsey, R.G., Richter, D.H., Riehle, J.R., Nye, C.J., Yount, M.E., and Dumoulin, J.A., 1998, Catalog of the historically active volcanoes of Alaska: U.S. Geological Survey Open-File Report 98-0582, 104 p.

Moran, S.C., Kwoun, O., Masterlark, T., and Lu, Z., 2006, On the absence of InSARdetected volcano deformation spanning the 1995-1996 and 1999 eruptions of Shishaldin Volcano, Alaska: Journal of Volcanology and Geothermal Research, v. 150, nos. 1-3, p. 119-131.

Neal, C.A., and McGimsey, R.G., 1997, 1996 volcanic activity in Alaska and Kamchatka-Summary of events and response of the Alaska Volcano Observatory: U.S. Geological Survey Open-File Report 97-433, 33 p.

Smithsonian Institution, 1995, Shishaldin: Bulletin of the Global Volcanism Network, v. 20, nos. 5, 11 and 12 .

Smithsonian Institution, 1996, Shishaldin: Bulletin of the Global Volcanism Network, v. 21, no. 1 . 
Selected References

\section{Eruption}

Beget, J., Nye, C., Gardner, J., Devine, J., and Stelling, P., 1999, Deposits of the 1999 Eruptions of Shishaldin Volcano, Unimak Island, Alaska [abs.]: Eos, Transactions, American Geophysical Union, v. 86, no. 49, Fall Meeting Supplement, Abstract V32A-09.

Caplan-Auerbach, J., and McNutt, S.R., 2003, New insights into the 1999 eruption of Shishaldin volcano, Alaska, based on acoustic data: Bulletin of Volcanology, v. 65 , p. 405-417.

Caplan-Auerbach, J., McNutt, S.R., Vergniolle, S., and Boichu, M., 2002, Acoustic Recordings of Strombolian and Subplinian Activity at Shishaldin Volcano, Alaska [abs.]: Eos, Transactions, American Geophysical Union, v. 83, Spring Meeting, Abstract V52A-10.

Dehn, J., Dean, K.G., Engle, K., and Izbekov, P., 2002, Thermal precursors in satellite images of the 1999 eruption of Shishaldin volcano: Bulletin of Volcanology, v. 64 , p. $525-534$.

Keith, T.C., Eichelberger, J.C., and Nye, C.J., 1999, The 1999 eruption of Shishaldin Volcano, Alaska-A successful example of "remote" monitoring [abs.]: Eos, Transactions, American Geophysical Union, v. 86, no. 49, Fall Meeting Supplement, Abstract V32A-04.

Masterlark, T., Lu, Z., Moran, S., and Wicks, C.W., 2001, Inflation rate of Shishaldin Volcano inferred from two-way stress coupling [abs.]: Eos, Transactions, American Geophysical Union, v. 82, no. 47, Fall Meeting Supplement, Abstract S21B-0584.

McGimsey, R.G., Neal, C.A., and Girina, O., 2004, 1999 volcanic activity in Alaska and Kamchatka-Summary of events and response of the Alaska Volcano Observatory: U.S. Geological Survey Open-File Report 2004-1033, 50 p.

McNutt, S.R., Dehn, J., and Gardner, J., 2000, Phreatic explosions at Shishaldin Volcano, Alaska, September 1999 to August 2000 [abs.]: Eos, Transactions, American Geophysical Union, v. 81, no. 48, Fall Meeting Supplement, Abstract V22B-12.

Moran, S.C., Stihler, S.D., and Power, J.A., 2002, A tectonic earthquake sequence preceding the April-May 1999 eruption of Shishaldin Volcano, Alaska: Bulletin of Volcanology, v. 64, p. 520-524.

Nye, C.J., Keith, T.E.C., Eichelberger, J.C., Miller, T.P., McNutt, S.R., Moran, S., Schneider, D.J., Dehn, J., and Schaefer, J.R., 2002, The 1999 eruption of 
Shishaldin Volcano, Alaska-Monitoring a distant eruption: Bulletin of Volcanology, v. 64, p. 507-519.

Schneider, D.J., Moran, S.C., and Nye, C.J., 1999, Volcanic clouds from the 1999 eruption of Shishaldin Volcano, Alaska - Comparisons of satellite, seismic, and geologic observations [abs.]: Eos, Transactions, American Geophysical Union, v. 80, no. 46, Fall Meeting Supplement, Abstract V32A-08.

Stelling, P., Beget, J., Nye, C., Gardner, J., Devine, J.D., and George, R.M.M., 2002, Geology and petrology of ejecta from the 1999 eruption of Shishaldin Volcano, Alaska: Bulletin of Volcanology, v. 64, p. 548-561.

Thompson, G., McNutt, S.R., and Tytgat, G., 2002, Three distinct regimes of volcanic tremor associated with the eruption of Shishaldin Volcano, Alaska 1999: Bulletin of Volcanology, v. 64, p. 535-547.

Vergniolle, S., Boichu, M., and Caplan-Auerbach, J., 2004, Acoustic measurements of the 1999 basaltic eruption of Shishaldin volcano, Alaska, 1- Origin of Strombolian activity: Journal of Volcanology and Geothermal Research, v. 137, nos. 1-3, p. 109-134.

Vergniolle, S., and Caplan-Auerbach, J., 2004, Acoustic measurements of the 1999 basaltic eruption of Shishaldin volcano, Alaska, 2-Precursor to the subplinian phase: Journal of Volcanology and Geothermal Research, v. 137, nos. 1-3, p. 135151.

Vergniolle, S., and Caplan-Auerbach, J., 2006, Basaltic thermals and subplinian plumes - Constraints from acoustic measurements at Shishaldin volcano, Alaska: Bulletin of Volcanology, v. 68, p. 611-630.

\section{Selected References}

\section{9-2000 Unrest}

Caplan-Auerbach, J., and Petersen, T., 2005, Repeating coupled earthquakes at Shishaldin Volcano, Alaska: Journal of Volcanology and Geothermal Research, v. 145, p. 151-172.

Neal, C.A., McGimsey, R.G., and Chubarova, O., 2004, 2000 volcanic activity in Alaska and Kamchatka-Summary of events and response of the Alaska Volcano Observatory: U.S. Geological Survey Open-File Report 2004-1034, 37 p.

Petersen, T., Caplan-Auerbach, J., McNutt, S.R., 2006, Sustained long-period seismicity at Shishaldin Volcano, Alaska: Journal of Volcanology and Geothermal Research, v. 151, p. 365-381. 
Smithsonian Institution, 2000, Shishaldin: Bulletin of the Global Volcanism Network, v. 25 , nos. 2 and 8.

\section{Selected References}

\section{Unrest}

Dixon, J.P., Stihler, S.D., Power, J.A., Tytgat, G., Moran, S.C., Sanchez, J.E., McNutt, S.R., and Paskievitch, J., 2003, Catalog of earthquake hypocenters at Alaskan volcanoes-January 1 through December 31, 2002: U.S. Geological Survey Open-File Report 03-0267, 58 p.

Petersen, T., 2007, Swarms of repeating long-period earthquakes at Shishaldin Volcano, Alaska, 2001-2004: Journal of Volcanology and Geothermal Research, v. 166, p. 177-192.

Smithsonian Institution, 2002, Shishaldin: Bulletin of the Global Volcanism Network, v. 27 , no. 5 .

\section{Comprehensive References}

\section{Eruption}

Neal, C.A., McGimsey, R.G., Dixon, J., and Melnikov, D., 2005, 2004 volcanic activity in Alaska and Kamchatka-Summary of events and response of the Alaska Volcano Observatory: U.S. Geological Survey Open-File Report 2005-1308, 71 p.

Petersen, T., 2007, Swarms of repeating long-period earthquakes at Shishaldin Volcano, Alaska, 2001-2004: Journal of Volcanology and Geothermal Research, v. 166, p. 177-192.

Petersen, T., and McNutt, S.R., 2007, Seismo-acoustic signals associated with degassing explosions recorded at Shishaldin Volcano, Alaska, 2003-2004: Bulletin of Volcanology, v. 69, no. 5, p. 527-536, doi: 10.1007/s00445-006-0088-z.

Smithsonian Institution, 2004, Shishaldin: Bulletin of the Global Volcanism Network, v. 29 , no. 6 .

\section{Comprehensive References}

\section{$\underline{2005 \text { Unrest }}$}

Dixon, J.P., Stihler, S.D., Power, J.A., Tytgat, G., Estes, S., and McNutt, S.R., 2006, Catalog of earthquake hypocenters at Alaskan volcanoes-January 1 through December 31, 2005: U.S. Geological Survey Open-File Report 2006-1264, 78 p.

McGimsey, R.G., Neal, C.A., Dixon, J.P., 2007, 2005 volcanic activity in Alaska, Kamchatka, and the Kurile Islands - Summary of events and response of the 
Alaska Volcano Observatory: U.S. Geological Survey Open-File Report 2007$5269,106 \mathrm{p}$.

\section{Dutton}

1102-011

Comprehensive References

\section{Unrest}

Davies, J.N., Taber, J., and Miller, T.P., 1988, Seismicity and geology of Mount Dutton, a volcano near the tip of the Alaska Peninsula [abs.]: Eos, Transactions, American Geophysical Union, v. 69, no. 44, p. 1507.

Miller, T.P., Chertkoff, D.G., Eichelberger, J.C., and Coombs, M.L., 1999, Mount Dutton volcano, Alaska-Aleutian arc analog to Unzen volcano, Japan: Journal of Volcanology and Geothermal Research, v. 89, p. 275-301.

Miller, T.P., McGimsey, R.G., Richter, D.H., Riehle, J.R., Nye, C.J., Yount, M.E., and Dumoulin, J.A., 1998, Catalog of the historically active volcanoes of Alaska: U.S. Geological Survey Open-File Report 98-0582, 104 p.

Smithsonian Institution, 1988, Dutton: Scientific Event Alert Network (SEAN) Bulletin v. 13 , nos. 7 and 8 .

Yount, M.E., Miller, T., Jacob, K.H., Reeder, J., and Power, J., 1991, Mt. Dutton, in Annual report of the world volcanic eruptions in 1988: Bulletin of Volcanic Eruptions, no. 28, p. 97-98. [appears in Bulletin of Volcanology, v. 53, 108-page supplement, January 1991]

\section{Pavlof}

1102-03-

Selected References

\section{Eruption}

McNutt, S.R., 1986, Observations and analysis of B-type earthquakes, explosions, and volcanic tremor at Pavlof Volcano, Alaska: Bulletin of the Seismological Society of America, v. 76, no. 1, p. 153-175.

McNutt, S.R., 1987a, Eruption characteristics and cycles at Pavlof volcano, Alaska, and their relation to regional earthquake activity: Journal of Volcanology and Geothermal Research, v. 31, p. 239-267.

McNutt, S.R., 1987b, Volcanic tremor at Pavlof volcano, Alaska, October 1973-April 1986: Pure and Applied Geophysics, v. 125, no. 6, 27 p. 
McNutt, S.R., 2004, Eruptions of Pavlof Volcano, Alaska, and their possible modulation by ocean load and tectonic stresses - Re-evaluation of the hypothesis based on new data from 1984-1998: Pure and Applied Geophysics, v. 155, no. 2-4, p. 701712.

McNutt, S.R., and Beavan, R.J., 1987, Eruptions of Pavlof Volcano and their possible modulation by ocean load and tectonic stresses: Journal of Geophysical Research, v. 92 , no. B11, p. 11509-11523.

Miller, T.P., McGimsey, R.G., Richter, D.H., Riehle, J.R., Nye, C.J., Yount, M.E., and Dumoulin, J.A., 1998, Catalog of the historically active volcanoes of Alaska: U.S. Geological Survey Open-File Report 98-0582, 104 p.

Smithsonian Institution, 1980, Pavlof: Scientific Event Alert Network (SEAN) Bulletin, v. 5 , nos. 7 and 11 .

\section{Selected References}

\section{Eruption}

McNutt, S.R., 1986, Observations and analysis of B-type earthquakes, explosions, and volcanic tremor at Pavlof Volcano, Alaska: Bulletin of the Seismological Society of America, v. 76, no. 1, p. 153-175.

McNutt, S.R., 1987a, Eruption characteristics and cycles at Pavlof volcano, Alaska, and their relation to regional earthquake activity: Journal of Volcanology and Geothermal Research, v. 31, p. 239-267.

McNutt, S.R., 1987b, Volcanic tremor at Pavlof volcano, Alaska, October 1973-April 1986: Pure and Applied Geophysics, v. 125, no. 6, 27 p.

McNutt, S.R., 2004, Eruptions of Pavlof Volcano, Alaska, and their possible modulation by ocean load and tectonic stresses-Re-evaluation of the hypothesis based on new data from 1984-1998: Pure and Applied Geophysics, v. 155, nos. 2-4, p. 701-712.

McNutt, S.R., and Beavan, R.J., 1987, Eruptions of Pavlof Volcano and their possible modulation by ocean load and tectonic stresses: Journal of Geophysical Research, v. 92, no. B11, p. 11509-11523.

Miller, T.P., McGimsey, R.G., Richter, D.H., Riehle, J.R., Nye, C.J., Yount, M.E., and Dumoulin, J.A., 1998, Catalog of the historically active volcanoes of Alaska: U.S. Geological Survey Open-File Report 98-0582, 104 p.

Smithsonian Institution, 1981, Pavlof: Scientific Event Alert Network (SEAN) Bulletin, v. 6 , no. 9 . 


\section{Selected References}

\section{$\underline{1983 \text { Eruptions }}$}

McNutt, S.R., 1986, Observations and analysis of B-type earthquakes, explosions, and volcanic tremor at Pavlof Volcano, Alaska: Bulletin of the Seismological Society of America, v. 76, no. 1, p. 153-175.

McNutt, S.R., 1987a, Eruption characteristics and cycles at Pavlof volcano, Alaska, and their relation to regional earthquake activity: Journal of Volcanology and Geothermal Research, v. 31, p. 239-267.

McNutt, S.R., 1987b, Volcanic tremor at Pavlof volcano, Alaska, October 1973-April 1986: Pure and Applied Geophysics, v. 125, no. 6, 27 p.

McNutt, S.R., 1999, Eruptions of Pavlof Volcano, Alaska, and their possible modulation by ocean load and tectonic stresses - Re-evaluation of the hypothesis based on new data from 1984-1998: Pure and Applied Geophysics, v. 155, nos. 2-4, p. 701-712.

McNutt, S.R., and Beavan, R.J., 1987, Eruptions of Pavlof Volcano and their possible modulation by ocean load and tectonic stresses: Journal of Geophysical Research, v. 92 , no. B11, p. 11509-11523.

Miller, T.P., McGimsey, R.G., Richter, D.H., Riehle, J.R., Nye, C.J., Yount, M.E., and Dumoulin, J.A., 1998, Catalog of the historically active volcanoes of Alaska: U.S. Geological Survey Open-File Report 98-0582, 104 p.

Smithsonian Institution, 1983, Pavlof: Scientific Event Alert Network (SEAN) Bulletin, v. 8 , nos. 10-12.

\section{Selected References}

\section{6-1988 Eruption}

McNutt, S.R., 1986, Observations and analysis of B-type earthquakes, explosions, and volcanic tremor at Pavlof Volcano, Alaska: Bulletin of the Seismological Society of America, v. 76, no. 1, p. 153-175.

McNutt, S.R., 1987a, Eruption characteristics and cycles at Pavlof volcano, Alaska, and their relation to regional earthquake activity: Journal of Volcanology and Geothermal Research, v. 31, p. 239-267.

McNutt, S.R., 1987b, Volcanic tremor at Pavlof volcano, Alaska, October 1973-April 1986: Pure and Applied Geophysics, v. 125, no. 6, 27 p.

McNutt, S.R., 1999, Eruptions of Pavlof Volcano, Alaska, and their possible modulation by ocean load and tectonic stresses-Re-evaluation of the hypothesis based on 
new data from 1984-1998: Pure and Applied Geophysics, v. 155, nos. 2-4, p. 701-712.

McNutt, S.R., and Beavan, R.J., 1987, Eruptions of Pavlof Volcano and their possible modulation by ocean load and tectonic stresses: Journal of Geophysical Research, v. 92, no. B11, p. 11509-11523.

McNutt, S.R., Miller, T.P., and Taber, J.J., 1991, Geological and seismological evidence of increased explosivity during the 1986 eruptions of Pavlof volcano, Alaska: Bulletin of Volcanology, v. 53, p. 86-98.

Miller, T.P., McGimsey, R.G., Richter, D.H., Riehle, J.R., Nye, C.J., Yount, M.E., and Dumoulin, J.A., 1998, Catalog of the historically active volcanoes of Alaska: U.S. Geological Survey Open-File Report 98-0582, 104 p.

Smithsonian Institution, 1986, Pavlof: Scientific Event Alert Network (SEAN) Bulletin, v. 11 , nos. $3,4,5,6,7,8,10,11$ and 12 .

Smithsonian Institution, 1987, Pavlof: Scientific Event Alert Network (SEAN) Bulletin, v. 12 , nos. $1,3,5,6,7,8,9,10$ and 11 .

Smithsonian Institution, 1988, Pavlof: Scientific Event Alert Network (SEAN) Bulletin, v. 13 , nos. 2,7 and 8 .

Comprehensive References

1990 Eruption

Miller, T.P., McGimsey, R.G., Richter, D.H., Riehle, J.R., Nye, C.J., Yount, M.E., and Dumoulin, J.A., 1998, Catalog of the historically active volcanoes of Alaska: U.S. Geological Survey Open-File Report 98-0582, 104 p.

Reeder, J.W., McNutt, S.R., and Abers, G.A., 1993, Pavlof, in Annual report of the world volcanic eruptions in 1990: Bulletin of Volcanic Eruptions, no. 30, p. 64-65. [appears in Bulletin of Volcanology, v. 55, 91-page supplement, March 1993]

\section{Selected References}

\section{6-1997 Eruption}

Garcés, M.A., and Hansen, R.A., 1998, Waveform analysis of seismoacoustic signals radiated during the Fall 1996 eruption of Pavlof volcano, Alaska: Geophysical Research Letters, v. 25, no. 7, p. 1051-1054.

Garcés, M.A., McNutt, S.R., Hansen, R.A., and Eichelberger, J.C., 2000, Application of wave-theoretical seismoacoustic models to the interpretation of explosion and eruption tremor signals radiated by Pavlof volcano, Alaska: Journal of Geophysical Research, v. 105, no. B2, p. 3039-3058. 
McGimsey, R.G., and Wallace, K., 1999, 1997 volcanic activity in Alaska and Kamchatka-Summary of events and response of the Alaska Volcano Observatory: U.S. Geological Survey Open-File Report 99-448, 42 p.

McNutt, S.R., 1999, Eruptions of Pavlof volcano, Alaska, and their possible modulation by ocean load and tectonic stresses - Re-evaluation of the hypothesis based on new data from 1984-1998: Pure and Applied Geophysics, v. 155, p. 701-712.

Neal, C.A., and McGimsey, R.G., 1997, 1996 volcanic activity in Alaska and Kamchatka-Summary of events and response of the Alaska Volcano Observatory: U.S. Geological Survey Open-File Report 97-433, 33 p.

Roach, A.L., Benoit, J.P., Dean, K.G., and McNutt, S.R., 2001, The combined use of satellite and seismic monitoring during the 1996 eruption of Pavlof volcano, Alaska: Bulletin of Volcanology, v. 62, p. 385-399.

\section{Selected References}

\section{Eruption}

McNutt, S.R., 2007, The 2007 eruption of Pavlof volcano, Alaska [abs.]: Eos, Transactions, American Geophysical Union, v. 88, no. 52, Fall Meeting Supplement, Abstract V52B-08.

McNutt, S., and Waythomas, C., 2008, Spatter construct-Ice interaction and lahar generation-An example from Pavlof Volcano, Alaska [abs.]: IAVCEI 2008 Abstracts, August 17-22, Reykjavik, Iceland, p. 79.

Venzke, E., Sennert, S.K., and Wunderman, R., 2007, Smithsonian Institution's Global Volcanism Network-Summary of recent volcanic activity: Bulletin of Volcanology, doi 10.1007/s00445-007-0188-4.

Wessels, R.L., Schneider, D., Ramsey, M., and Mangan, M.T., 2007, ASTER observations of 2000-2007 thermal features at Pavlof Volcano and Mt. Hague (Emmons Lake Volcanic Center), Alaska [abs.]: Eos, Transactions, American Geophysical Union, v. 88, no. 52, Fall Meeting Supplement, Abstract V41A0399.

Smithsonian Institution, 2007, Shishaldin: Bulletin of the Global Volcanism Network, v. 32 , no. 8 . 


\title{
Veniaminof
}

\section{Selected References}

\author{
1102-07-
}

\section{3-1984; 1984 Eruption}

Miller, T.P., McGimsey, R.G., Richter, D.H., Riehle, J.R., Nye, C.J., Yount, M.E., and Dumoulin, J.A., 1998, Catalog of the historically active volcanoes of Alaska: U.S. Geological Survey Open-File Report 98-0582, 104 p.

Miller, T., Yount, E., and McNutt, S., 1986, Veniaminof, in Annual report of the world volcanic eruptions in 1983: Bulletin of Volcanic Eruptions, no. 23, p. 39. [appears in Bulletin of Volcanology, v. 48, 25-page supplement, January 1987]

Smithsonian Institution, 1983, Veniaminof: Scientific Event Alert Network (SEAN) Bulletin, v. 8, nos. 5, 6, 7, 8, 9, 10, 11 and 12 .

Smithsonian Institution, 1984, Veniaminof: Scientific Event Alert Network (SEAN) Bulletin, v. 9, nos. 1, 2, 3, 4, 5, 8, 11 and 12 .

Waythomas, C., Miller, T.P., Welch, B., Calvert, A., Bacon, C.R., and Wallace, K.L., 2007, Volcano-glacier interactions at Mount Veniaminof Volcano, a large icefilled caldera on the Alaska Peninsula [abs.]: Geological Society of America Abstracts with Programs, v. 39, no. 4, p. 20.

Yount, M.E., and Miller, T.P., 1987, Hazard implications of the 1983-1984 eruption of Mt. Veniaminof [abs.]: Geologic Hazards Symposium, Alaska Geological Society Symposium Agenda and Abstracts, Anchorage Alaska, May 12-15, 1987, unpaged.

Yount, M.E., Miller, T.P., Emanuel, R.P., and Wilson, F.H., 1985, Eruption in an icefilled caldera, Mount Veniaminof, Alaska Peninsula: in Bartsch-Winkler, S., and Reed, K.M., eds., The United States Geological Survey in Alaska; accomplishments during 1983: U.S. Geological Survey Circular 945, p 59-60.

Yount, E., Miller, T., Taber, J., and Hudnut, K., 1987, Veniaminof, in Annual report of the world volcanic eruptions in 1984: Bulletin of Volcanology, no. 24, p. 38-39. [appears in Bulletin of Volcanology, v. 49, 52-page supplement, January 1987]

\section{Selected References}

\section{3-1994 Eruption}

Dean, K., 1993, The 1993 eruption of Veniaminof Volcano, Alaska [abs.]: Eos, Transactions, American Geophysical Union, v. 74, no. 43, p. 74. 
Miller, T.P., McGimsey, R.G., Richter, D.H., Riehle, J.R., Nye, C.J., Yount, M.E., and Dumoulin, J.A., 1998, Catalog of the historically active volcanoes of Alaska: U.S. Geological Survey Open-File Report 98-0582, 104 p.

Neal, C.A., 1996, Veniaminof, in Annual report of the world volcanic eruptions in 1993: Bulletin of Volcanic Eruptions, no. 33, p. 94-96. [appears in Bulletin of Volcanology, v. 58, 132-page supplement, March 1996]

Neal, C.A., Doukas, M.P., and McGimsey, R.G., 1995, 1994 volcanic activity in Alaska-Summary of events and response of the Alaska Volcano Observatory: U.S. Geological Survey Open-File Report 95-0271, 18 p.

Neal, C.A., McGimsey, R.G., and Doukas, M.P., 1996, 1993 volcanic activity in Alaska-Summary of events and response of the Alaska Volcano Observatory: U.S. Geological Survey Open-File Report 96-24, 21 p.

\section{Selected References}

\section{Eruption}

Miller, T.P., McGimsey, R.G., Richter, D.H., Riehle, J.R., Nye, C.J., Yount, M.E., and Dumoulin, J.A., 1998, Catalog of the historically active volcanoes of Alaska: U.S. Geological Survey Open-File Report 98-0582, 104 p.

Neal, C.A., Doukas, M.P., and McGimsey, R.G., 1995, 1994 volcanic activity in Alaska-Summary of events and response of the Alaska Volcano Observatory: U.S. Geological Survey Open-File Report 95-271, 20 p.

Neal, C.A., McGimsey, R.G., and Doukas, M.P., 1996, 1993 volcanic activity in Alaska-Summary of events and response of the Alaska Volcano Observatory: U.S. Geological Survey Open-File Report 96-24, 21 p.

Selected References

\section{2-2003 Eruption}

McGimsey, R.G., Neal, C.A., and Girina, O., 2005, 2003 volcanic activity in Alaska and Kamchatka-Summary of events and response of the Alaska Volcano Observatory: U.S. Geological Survey Open-File Report 2005-1310, 62 p.

Neal, C.A., McGimsey, R.G., and Girina, O., 2004, 2002 volcanic activity in Alaska and Kamchatka-Summary of events and response of the Alaska Volcano Observatory: U.S. Geological Survey Open-File Report 2004-1058, 55 p.

Smithsonian Institution, 2002, Veniaminof: Bulletin of the Global Volcanism Network, v. 27 , no. 10 
Smithsonian Institution, 2003, Veniaminof: Bulletin of the Global Volcanism Network, v. 28 , nos. 1 and 3

\section{Selected References}

\section{$\underline{2004}$ Eruption}

Neal, C.A., McGimsey, R.G., Dixon, J., and Melnikov, D., 2005, 2004 volcanic activity in Alaska and Kamchatka-Summary of events and response of the Alaska Volcano Observatory: U.S. Geological Survey Open-File Report 2005-1308, 71 p.

Sanchez, J.J., and McNutt, S.R., 2004, Seismicity of Mt. Veniaminof, AlaskaImplications for an active magmatic system [abs.]: Eos, Transactions, American Geophysical Union, v. 85, no. 47, Fall Meeting Supplement, Abstract V14B-07.

Smithsonian Institution, 2004, Veniaminof: Bulletin of the Global Volcanism Network, v. 29 , no. 6 .

\section{Selected References}

\section{Eruptions}

De Angelis, S., and McNutt, S.R., 2005, Eruption and earthquake activity at Mt. Veniaminof, Alaska, during January-February 2005 [abs.]: Eos, Transactions, American Geophysical Union, v. 86, p. 52.

De Angelis, S., and McNutt, S.R., 2007, Observations of volcanic tremor during the January-February 2005 eruption of Mt. Veniaminof, Alaska: Bulletin of Volcanology, v. 69, p. 927-940.

DeRoin, N., McNutt, S.R., Williams, E., 2005, Seismic, webcam and satellite observations of eruptions at Veniaminof Volcano, Alaska, January-February 2005 [abs]: Eos, Transactions, American Geophysical Union, v. 86, p. 52, Fall Meeting Supplement, Abstract V21C-0616.

McGimsey, R.G., Neal, C.A., and Dixon, J.P., 2007, 2005 volcanic activity in Alaska, Kamchatka, and the Kurile Islands - Summary of events and response of the Alaska Volcano Observatory: U.S. Geological Survey Open-File Report 20075269, $106 \mathrm{p}$.

Smithsonian Institution, 2005, Veniaminof: Bulletin of the Global Volcanism Network, v. 30 , no. 2 . 
Comprehensive References

$\underline{2006}$ Eruption

Dixon, J.P., Stihler, S.D., Power, J.A., and Searcy, C., 2008, Catalog of earthquake hypocenters at Alaskan volcanoes-January 1 through December 31, 2006: U.S. Geological Survey Data Series 326, 79 p.

Smithsonian Institution, 2006, Veniaminof: Bulletin of the Global Volcanism Network, v. 31 , nos. 3 and 8 .

Comprehensive References

$\underline{2008 \text { Eruption }}$

Smithsonian Institution, 2008, Veniaminof: Bulletin of the Global Volcanism Network, v. 33 , no. 5 .

\section{Chiginagak}

1102-11-

Comprehensive References

\section{7-1998 Unrest}

McGimsey, R.G., Neal, C.A., and Girina, O., 2003, 1998 volcanic activity in Alaska and Kamchatka-Summary of events and response of the Alaska Volcano Observatory: U.S. Geological Survey Open-File Report 03-423, 38 p.

McGimsey, R.G., and Wallace, K., 1999, 1997 volcanic activity in Alaska and Kamchatka-Summary of events and response of the Alaska Volcano Observatory: U.S. Geological Survey Open-File Report 99-448, 42 p.

Miller, T.P., McGimsey, R.G., Richter, D.H., Riehle, J.R., Nye, C.J., Yount, M.E., and Dumoulin, J.A., 1998, Catalog of the historically active volcanoes of Alaska: U.S. Geological Survey Open-File Report 98-0582, 104 p.

Smithsonian Institution, 1997, Chiginagak: Bulletin of the Global Volcanism Network, v. 22 , no. 11 .

Smithsonian Institution, 1998, Chiginagak: Bulletin of the Global Volcanism Network, v. 23 , nos. 1,3 and 8.

Comprehensive References

2004-2005 Unrest

Giles, J., 2008, Volcano spews lethal acid brew: New Scientist, v. 199, no. 2664, p. 14. 
McGimsey, R.G., Neal, C.A., and Dixon, J.P., 2007, 2005 volcanic activity in Alaska, Kamchatka, and the Kurile Islands - Summary of events and response of the Alaska Volcano Observatory: U.S. Geological Survey Open-File Report 2007$5269,106 \mathrm{p}$.

Neal, C.A., McGimsey, R.G., Dixon, J., and Melnikov, D., 2005, 2004 volcanic activity in Alaska and Kamchatka-Summary of events and response of the Alaska Volcano Observatory: U.S. Geological Survey Open-File Report 2005-1308, 71 p.

Pfeffer, M., and Schaefer, J., 2008, Modeling the phytotoxic gas flow released during the crater lake breakout of Chiginagak Volcano [abs.]: IAVCEI 2008 Abstracts, August 17-22, Reykjavik, Iceland, p. 71.

Schaefer, J.R., 2006, The 2005 crater lake formation, lahar, acidic flood, and caustic aerosol and gas release from Chiginagak Volcano, Alaska [abs.]: Geological Society of America Abstracts with Programs, Cordilleran Section Annual Meeting, v. 38, no. 5, p. 29.

Schaefer, J.R., Scott, W.E., Evans, W.C., Jorgenson, J., McGimsey, R.G., and Wang, B., 2008, The 2005 catastrophic acid crater lake drainage, lahar, and acidic aerosol formation at Mount Chiginagak volcano, Alaska, USA - Field observations and preliminary water and vegetation chemistry results: Geochemistry Geophysics Geosystems, v. 9, no. 7, 29 p. Q07018, doi:10.1029/2007GC001900.

Schaefer, J.R., Scott, W.E., McGimsey, R.G., and Jorgenson, J., 2005, 2005 crater lake formation, lahar, acidic flood, and gas emission from Chiginagak Volcano, Alaska [abs.]: Eos, Transactions, American Geophysical Union, v. 86, no. 52, Fall Meeting Supplement, Abstract V21E-0675.

\section{Martin}

1102-14-

Comprehensive References

\section{Unrest}

Dixon, J.P., Prejean, S.G., and Power, J.A., 2007, The January 2006 volcanic-tectonic earthquake swarm at Mount Martin, Alaska [abs.]: Seismological Research Letters, v. 78, no. 2, p. 255.

Dixon, J.P., Stihler, S.D., Power, J.A., and Searcy, C., 2008, Catalog of earthquake hypocenters at Alaskan volcanoes-January 1 through December 31, 2006: U.S. Geological Survey Data Series 326, 79 p. 


\section{Fourpeaked}

\section{Comprehensive References}

1102-26-

\section{Eruption}

Cervelli, P.F., and West, M., 2007, The 2006 eruption of Fourpeaked volcano, Katmai National Park, Alaska [abs.]: Eos, Transactions, American Geophysical Union, v. 88, no. 52, Fall Meeting Supplement, Abstract V31E-0719.

Dixon, J.P., Stihler, S.D., Power, J.A., and Searcy, C., 2008, Catalog of earthquake hypocenters at Alaskan volcanoes_January 1 through December 31, 2006: U.S. Geological Survey Data Series 326, 79 p.

Smithsonian Institution, 2006, Fourpeaked: Bulletin of the Global Volcanism Network, v. 31, no. 9 .

Werner, C., Doukas, M., Cervelli, P., and Carn, S.A., 2008, Gas emissions related to heightened activity at Fourpeaked Volcano, 2006-2007, Katmai National Park, Alaska [abs.]: IAVCEI 2008 Abstracts, August 17-22, Reykjavik, Iceland, p. 33.

Zielinski, S., 2006, In brief-Explosion at dormant Alaskan volcano: Eos, Transactions, American Geophysical Union, v. 87, no. 41, p. 435, doi:10.1029/2006EO410008.

\section{Ukinrek Maars/Ugashik-Peulik}

1102-131/1102-13-

Selected References

\section{Unrest}

Lu, Z., Wicks, C., Jr., Dzurisin, D., Power, J.A., Moran, S.C., and Thatcher, W., 2002, Magmatic inflation at a dormant stratovolcano-1996-1998 activity at Mount Peulik volcano, Alaska, revealed by satellite radar interferometry: Journal of Geophysical Research, v. 107, no. B7, 13 p.

Lu, Z., Wicks, C., Dzurisin, D., Power, J.A., and Thatcher, W., 2000, Satellite radar interferometry detected surface deformation at a dormant Aleutian volcano [abs.]: Eos, Transactions, American Geophysical Union, v. 81, no. 48, Fall Meeting Supplement, Abstract V21B-09.

McGimsey, R.G., Neal, C.A., and Girina, O., 2003, 1998 volcanic activity in Alaska and Kamchatka - Summary of events and response of the Alaska Volcano Observatory: U.S. Geological Survey Open-File Report 03-423, 38 p.

Miller, T.P., McGimsey, R.G., Richter, D.H., Riehle, J.R., Nye, C.J., Yount, M.E., and Dumoulin, J.A., 1998, Catalog of the historically active volcanoes of Alaska: U.S. Geological Survey Open-File Report 98-0582, 104 p. 
Moran, S.C., Haeussler, P., and Power, J., 2001, Seismic studies in the Mount Peulik/Becharof Lake area, Alaska [abs.]: Earthscope science meeting, 4 p.

Ort, M.H., Wohletz, K.H., Neal, C.A., and McConnell, V.S., 1995, Mechanics of magma/ water interaction, Ukinrek Maars, Alaska [abs.] in International Union of Geodesy and Geophysics, General Assembly, 21, International Union of Geodesy and Geophysics: XXI general assembly, p. 467.

Smithsonian Institution, 1998, Ukinrek Maars: Bulletin of the Global Volcanism Network, v. 23, nos. 4 and 5.

\title{
Selected References
}

\section{$\underline{1986 \text { Eruption }}$}

\section{Augustine}

\author{
1103-01-
}

Getahun, A., Reed, M.H., and Symonds, R., 1996, Mount St. Augustine volcano fumarole wall rock alteration-Mineralogy, zoning, composition and numerical models of its formation process: Journal of Volcanology and Geothermal Research, v. 71, p. 73-107.

Holasek, R.E., and Rose, W.I., 1991, Anatomy of 1986 Augustine volcano eruptions as recorded by multispectral image processing of digital AVHRR weather satellite data: Bulletin of Volcanology, v. 53, p. 420-435.

Kienle, J., Kowalik, Z., and Murty, T.S., 1987, Tsunamis generated by eruptions from Mount St. Augustine Volcano, Alaska: Science, v. 236, no. 4807, p. 1442-1447.

Kleist, T., 1986, Augustine Volcano erupts quietly: Science News, v. 130, no. 10, p. 149.

Kodosky, L., and Keskinen, M., 1990, Fumarole distribution, morphology, and encrustation mineralogy associated with the 1986 eruptive deposits of Mount St. Augustine, Alaska: Bulletin of Volcanology, v. 52, p. 175-185.

Kodosky, L.G., Motyka, R.J., and Symonds, R.B., 1991, Fumarolic emissions from Mount St. Augustine, Alaska-1979-1984 degassing trends, volatile sources and their possible role in eruptive style: Bulletin of Volcanology, v. 53, p. 381-394.

Masterlark, T., Lu, Z., and Rykhus, R., 2006, Thickness distribution of a cooling pyroclastic flow deposit on Augustine Volcano, Alaska-Optimization using InSAR, FEMs, and an adaptive mesh algorithm: Journal of Volcanology and Geothermal Research, v. 150, p. 186-201. 
Power, J., 1988, Seismicity associated with the 1986 eruption of Augustine Volcano, Alaska: University of Alaska, unpub. master's thesis $142 \mathrm{p}$.

Roman, D.C., Cashman, K.V., Gardner, C.A., Wallace, P.J., and Donovan, J.J., 2006, Storage and interaction of compositionally heterogeneous magmas from the 1986 eruption of Augustine Volcano, Alaska: Bulletin of Volcanology, v. 68, p. 240254, doi:10.1007/s00445-005-0003-z.

Rose, W.I., Heiken, G., Wohletz, K., Eppler, D., Barr, S., Miller, T., Chuan, R.L., and Symonds, R.B., 1988, Direct rate measurements of eruption plumes at Augustine Volcano-A problem of scaling and uncontrolled variables: Journal of Geophysical Research, v. 93, no. B5, p. 4485-4499.

Swanson, S.E., and Kienle, J., 1988, The 1986 eruption of Mount St. Augustine-Field test of hazard evaluation: Journal of Geophysical Research, v. 93, no. B5, p. 4500-4520.

Symonds, R.B., Rose, W.I., Gerlach, T.M., Briggs, P.H., and Harmon, R.S., 1990, Evaluation of gases, condensates, and $\mathrm{SO}_{2}$ emissions from Augustine volcano, Alaska - The degassing of a Cl-rich volcanic system: Bulletin of Volcanology, v. 52 , p. $355-374$.

\section{Selected References}

\section{5-2006 Eruption}

Bull, K.F., Vallance, J.W., and Coombs, M.L., 2006, Pyroclastic flows, lahars, and mixed avalanches generated during the 2005-2006 eruption of Augustine Volcano, Alaska [abs.]: Eos, Transactions, American Geophysical Union, v. 87, no. 52, Fall Meeting Supplement, Abstract V41F-07.

Cervelli, P.F., Fournier, T., Freymueller, J., and Power, J.A., 2006, Ground deformation associated with the precursory unrest and early phases of the January 2006 eruption of Augustine Volcano, Alaska: Geophysical Research Letters, v. 33, 5 p., doi:10.1029/2006GL027219.

Dean, K.G., Dehn, J., Wallace, K.L., Prata, F., and Cahill, C.F., 2006, The distribution and movement of volcanic ash and $\mathrm{SO}_{2}$ observed in satellite data from the eruption of Augustine Volcano, 2006 [abs.]: Eos, Transactions, American Geophysical Union, v. 87, no. 52, Fall Meeting Supplement, Abstract V41F-05.

McGee, K.A., Doukas, M.P., McGimsey, R.G., Neal, C.A., and Wessels, R.L., 2008, Atmospheric contribution of gas emissions from Augustine volcano, Alaska during the 2006 eruption: Geophysical Research Letters, v. 35, L03306, doi:10.1029/2007GL032301, 5 p. 
McGimsey, R.G., Neal, C.A., and Dixon, J.P., 2007, 2005 volcanic activity in Alaska, Kamchatka, and the Kurile Islands - Summary of events and response of the Alaska Volcano Observatory: U.S. Geological Survey Open-File Report 20075269,106 p.

Nye, C.J., 2006, Introduction to Augustine Volcano and overview of the 2006 eruption [abs.]: Eos, Transactions, American Geophysical Union, v. 87, no. 52, Fall Meeting Supplement, Abstract V41F-01.

Power, J.A., and Lalla, D.J., 2006, Seismic observations of the Augustine magmatic system: 1970-2006 [abs.]: Eos, Transactions, American Geophysical Union v. 87, no. 52, Fall Meeting Supplement, Abstract V41F-03.

Power, J.A., Nye, C.J., Coombs, M.L., Wessels, R.L., Cervelli, P.F., Dehn, J., Wallace, K.L., Freymueller, J.T., and Doukas, M.P., 2006, The reawakening of Alaska's Augustine Volcano: Eos, Transactions, American Geophysical Union, v. 87, no. 37, doi:10.1029/2006EO370002.

Wallace, K., Neal, C., and McGimsey, G., 2006, Timing, distribution, and character of tephra fall from the 2005-2006 eruption of Augustine Volcano, Alaska [abs.]: Eos, Transactions, American Geophysical Union, v. 87, no. 52, Fall Meeting Supplement, Abstract V41F-06.

\section{Selected References}

\section{Iliamna}

\section{6-1997 Unrest}

McGimsey, R.G., and Wallace, K., 1999, 1997 volcanic activity in Alaska and Kamchatka-Summary of events and response of the Alaska Volcano Observatory: U.S. Geological Survey Open-File Report 99-448, 42 p.

McNutt, S.R., and Marzocchi, W., 2004, Simultaneous earthquake swarms and eruption in Alaska, Fall 1996-Statistical significance and inference of a large aseismic slip event: Bulletin of the Seismological Society of America, v. 94, no. 5, p. 18311841.

Neal, C.A., and McGimsey, R.G., 1997, 1996 volcanic activity in Alaska and Kamchatka-Summary of events and response of the Alaska Volcano Observatory: U.S. Geological Survey Open-File Report 97-433, 33 p.

Roman, D.C., Power, J.A., Moran, S.C., Cashman, K.V., Doukas, M.P., Neal, C.A., and Gerlach, T.M., 2004, Evidence for dike emplacement beneath Iliamna Volcano, Alaska in 1996: Journal of Volcanology and Geothermal Research, v. 130, p. 265284. 
Smithsonian Institution, 1996, Iliamna: Bulletin of the Global Volcanism Network, v. 21, nos. $8,9,10$ and 12 .

Smithsonian Institution, 1997, Iliamna: Bulletin of the Global Volcanism Network, v. 22, no. 9.

\section{Redoubt}

1103-03-

\section{Selected References}

\section{9-1990 Eruption}

Benz, H.M., Chouet, B.A., Dawson, P.B., Lahr, J.C., Page, R.A., and Hole, J.A., 1996, Three-dimensional P and S wave velocity structure of Redoubt Volcano, Alaska: Journal of Geophysical Research, v. 101, no. B4, p. 8111-8128.

Brantley, S.R., ed., 1990, The eruption of Redoubt Volcano, Alaska, December 14,1989August 31,1990: U.S. Geological Survey Circular 1061, 39 p.

Browne, B.L., and Gardner, J.E., 2006, The influence of magma ascent path on the texture, mineralogy, and formation of hornblende reaction rims: Earth and Planetary Science Letters, v. 246, no. 3-4, p. 161-176.

Heffter, J.L., Stunder, B.J.B., and Rolph, G.D., 1990, Long-range forecast trajectories of volcanic ash from Redoubt Volcano eruptions: Bulletin of the American Meteorological Society, v. 71, no. 12, p. 1731-1738.

Hobbs, P.V., Radke, L.F., Lyons, J.H., Ferek, R.J., Coffman, D.J., and Casadevall, T.J., 1991, Airborne measurements of particle and gas emissions from the 1990 volcanic eruptions of Mount Redoubt: Journal of Geophysical Research, v. 96, no. D10, p. 18735-18752.

Miller, T.P., and Chouet, B.A., eds., 1994, The 1989-1990 eruptions of Redoubt Volcano: Journal of Volcanology and Geothermal Research, v. 62, p. 1-530.

Morrissey, M., 1997, Long-period seismicity at Redoubt Volcano, Alaska, 1989-1990 related to magma degassing: Journal of Volcanology and Geothermal Research, v. 75 , p. 321-335.

Morrissey, M.M., and Chouet, B.A., 1997, A numerical investigation of choked flow dynamics and its application to the triggering mechanism of long-period events at Redoubt Volcano, Alaska: Journal of Geophysical Research, v. 102, no. B4, p. 7965-7983. 
Munoz, O., Volten, H., Hovenier, J.W., Veihelmann, B., van der Zande, W.J., Waters, L.B.F.M, and Rose, W.I., 2004, Scattering matrices of volcanic ash particles of Mount St. Helens, Redoubt, and Mount Spurr Volcanoes: Journal of Geophysical Research, v. 109, D16201.

Stephens, C.D., and Chouet, B.A., 2001, Evolution of the December 14, 1989 precursory long-period event swarm at Redoubt Volcano, Alaska: Journal of Volcanology and Geothermal Research, v. 109, p. 133-148.

Wolf, K., Jr., and Eichelberger, J.C., 1997, Syneruptive mixing, degassing, and crystallization at Redoubt Volcano, eruption of December, 1989 to May 1990: Journal of Volcanology and Geothermal Research, v. 75, p. 19-37.

\section{Comprehensive References}

\section{Unrest}

Smithsonian Institution, 2008, Redoubt: Bulletin of the Global Volcanism Network, v. 33, no. 11 .

\section{Spurr}

1103-04-

Selected References

\section{Eruption}

Gardner, C.A., Cashman, K.V., and Neal, C.A., 1998, Tephra-fall deposits from the 1992 eruption of Crater Peak, Alaska-Implications of clast textures for eruptive processes: Bulletin of Volcanology, v. 59, p. 537-555.

Jolly, A.D., Page, R.A., and Power, J.A., 1994, Seismicity and stress in the vicinity of Mount Spurr volcano, south central Alaska: Journal of Geophysical Research, v. 99, no. B8, p. 15,305-15,318.

Keith, T.E.C., ed., The 1992 Eruptions of Crater Peak Vent, Mount Spurr Volcano, Alaska: U.S. Geological Survey Bulletin 2139, 220 p.

Krotkov, N.A., Torres, O., Seftor, C., Krueger, A.J., Kostinski, A., Rose, W.I., Bluth, G.J.S., Schneider, D., and Schaefer, S.J., 1999, Comparison of TOMS and AVHRR volcanic ash retrievals from the August 1992 eruption of Mount Spurr: Geophysical Research Letters, v. 26, no. 4, p. 455-458.

McGimsey, R.G., Neal, C.A., and Riley, C.M., 2001, Areal distribution, thickness, mass, volume, and grain size of tephra-fall deposits from the 1992 eruptions of Crater Peak Vent, Mt. Spurr Volcano, Alaska: U.S. Geological Survey Open-File Report 01-370, $38 \mathrm{p}$. 
McNutt, S.R., and Davis, C.M., 2000, Lightning associated with the 1992 eruptions of Crater Peak, Mount Spurr Volcano, Alaska: Journal of Volcanology and Geothermal Research, v. 102, p. 45-65.

Power, J.A., Jolly, A.D., Nye, C.J., and Harbin, M.L., 2002, A conceptual model of the Mount Spurr magmatic system from seismic and geochemical observations of the 1992 Crater Peak eruption sequence: Bulletin of Volcanology, v. 64, p. 206-218.

Power, J.A., Villasensor, A., and Benz, H.M., 1998, Seismic image of the Mount Spurr magmatic system: Bulletin of Volcanology, v. 60, p. 27-37.

Rose, W.I., Bluth, G.J.S., Schneider, D.J., Ernst, G.G.J., Riley, C.M., Henderson, L.J., and McGimsey, R.G., 2001, Observations of volcanic clouds in their first few days of atmospheric residence-The 1992 eruptions of Crater Peak, Mount Spurr Volcano, Alaska: The Journal of Geology, v. 109, p. 677-694

Roman, D.C., Moran, S.C., Power, J.A., and Cashman, K.V., 2004, Temporal and spatial variation of local stress fields before and after the 1992 eruptions of Crater Peak Vent, Mount Spurr Volcano, Alaska: Bulletin of the Seismological Society of America, v. 94, no. 6, p. 2366-2379.

Waythomas, C.F., 2001, Formation and failure of volcanic debris dams in the Chakachatna River valley associated with eruptions of the Spurr volcanic complex, Alaska: Geomorphology, v. 39, p. 111-129.

Wiemer, S., and McNutt, S.R., 1997, Variations in the frequency-magnitude distribution with depth in two volcanic areas: Mount St. Helens, Washington, and Mt. Spurr, Alaska: Geophysical Research Letters, v. 24, no. 2, p. 189-192.

Comprehensive References

2004-2005 Unrest

Coombs, M.L., Neal, C.A., Wessels, R.L., and McGimsey, R.G., 2005, Geothermal disruption of summit glaciers at Mount Spurr Volcano, 2004-6-An unusual manifestation of volcanic unrest: U.S. Geological Survey Professional Paper 1732-B, $33 \mathrm{p}$.

De Angelis, S., and McNutt, S. R., 2005, Degassing and hydrothermal activity at Mt. Spurr, Alaska during the summer of 2004 inferred from the complex frequencies of long-period events: Geophysical Research Letters, v. 32, L12312, doi:10.1029/2005GL022618, 4 p.

Dixon, J.P., Stihler, S.D., Power, J.A., Tytgat, G., Estes, S., and McNutt, S.R., 2006, Catalog of earthquake hypocenters at Alaskan volcanoes - January 1 through December 31, 2005: U.S. Geological Survey Open-File Report 2006-1264, 78 p. 
Dixon, J.P., Stihler, S.D., Power, J.A., Tytgat, G., Estes, S., Prejean, S., Sanchez, J.J., Sanches, R., McNutt, S.R., and Paskievitch, J., 2005, Catalog of earthquake hypocenters at Alaskan volcanoes_-January 1 through December 31, 2004: U.S. Geological Survey Open-File Report 2005-1312, 74 p.

McGimsey, R.G., Neal, C.A., and Dixon, J.P., 2007, 2005 volcanic activity in Alaska, Kamchatka, and the Kurile Islands-Summary of events and response of the Alaska Volcano Observatory: U.S. Geological Survey Open-File Report 2007$5269,106 \mathrm{p}$.

Neal, C.A., Coombs, M., Wessels, R., and McGimsey, R.G., 2007, Volcanic disruption of summit ice at Mount Spurr Volcano, Alaska, 2004-2007 [abs.]: Geological Society of America, Abstracts with Programs, v. 39, no. 4, p. 20.

Neal, C.A., McGimsey, R.G., Dixon, J., and Melnikov, D., 2005, 2004 volcanic activity in Alaska and Kamchatka-Summary of events and response of the Alaska Volcano Observatory: U.S. Geological Survey Open-File Report 2005-1308, 71 p.

Power, J.A., 2004, Renewed unrest at Mount Spurr Volcano, Alaska [abs.]: Eos, Transactions, American Geophysical Union, v. 85, no. 43, p. 434, doi:10.1029/2004EO430004.

Smithsonian Institution, 2004, Spurr: Bulletin of the Global Volcanism Network, v. 29, no. 10.

Comprehensive References

Agrigan

0804-16=

\section{Unrest}

Mitchell, E.C., 2005, Volatile chemistry, and nitrogen sources and fluxes, in subduction zones-Insights from the Izu-Bonin-Mariana Arc: University of Liverpool, M.E.SCI Thesis, $120 \mathrm{p}$.

Shaw, A.M., Hauri, E.H., Hilton, D.R., Fischer, T.P., Stern, R.J., Wade, J., and Plank, T., 2004, Insights into arc fluid budgets from Mariana melt inclusions [abs.]:

Goldschmidt Conference, Copenhagen, Abstract 1.2.23, p. A45.

Smithsonian Institution, 1990, Agrigan: Scientific Event Alert Network (SEAN) Bulletin, v. 15 , nos. 7,9 and 10 . 
Comprehensive References

Pagan

0804-17=

\section{1-1985 Eruption}

Banks, N.G., Koyanagi, R.B., Sinton, J.M., and Honma, K.T., 1984, The eruption of Mount Pagan volcano, Mariana Islands, 15 May 1981: Journal of Volcanology and Geothermal Research, v. 22, p. 225-269.

Ernest Raj, P., and Devara, P.C.S., 1997, Seasonal/latitudinal variations in the satellite observed aerosol properties in the stratosphere and upper troposphere during the eruption of Alaid and Pagan: Indian Journal of Radio and Space Physics, v. 26, no. 5 , p. 256-263.

Ernst, G.G.J., Davis, J.P., and Sparks, S.J., 1994, Bifurcation of volcanic plumes in a crosswind: Bulletin of Volcanology, v. 56, no. 3, p. 159-169.

Sawada, Y., 1983, Analysis of eruption clouds by the 1981 eruptions of Alaid and Pagan volcanoes with GMS images: Papers in Meteorology and Geophysics, v. 34, p. 307-324.

Smithsonian Institution, 1981, Pagan: Scientific Event Alert Network (SEAN) Bulletin, v. 6 , nos. $4,5,6,9$ and 11 .

Smithsonian Institution, 1982, Pagan: Scientific Event Alert Network (SEAN) Bulletin, v. 7 , nos. 2 and 11 .

Smithsonian Institution, 1983, Pagan: Scientific Event Alert Network (SEAN) Bulletin, v. 8 , nos. $3,8,9$ and 10 .

Smithsonian Institution, 1984, Pagan: Scientific Event Alert Network (SEAN) Bulletin, v. 9 , no. 4.

Smithsonian Institution, 1985, Pagan: Scientific Event Alert Network (SEAN) Bulletin, v. 10 , no. 4 .

Trusdell, F.A., Moore, R.B., and Sako, M.K., 2006, Preliminary geologic map of Mount Pagan Volcano, Pagan Island, Commonwealth of the Northern Mariana Islands: U.S. Geological Survey Open-File Report 2006-1386, 32 p.

Comprehensive References

1987 Eruption

Smithsonian Institution, 1987, Pagan: Scientific Event Alert Network (SEAN) Bulletin, v. 12 , no. 8 . 
Comprehensive References

1988 Eruption

Smithsonian Institution, 1988, Pagan: Scientific Event Alert Network (SEAN) Bulletin, v. 13 , nos. 2 and $8-10$.

Comprehensive References

1992 Eruption

Smithsonian Institution, 1992, Pagan: Bulletin of the Global Volcanism Network, v. 17, no. 6.

Comprehensive References

1993 Eruption

Koyanagi, R., Kojima, G., Chong, F., and Chong, R., 1993, Seismic monitoring of earthquakes and volcanoes in the Northern Mariana Islands-1993 summary report: Prepared for the Office of the Governor, Commonwealth of the Northern Mariana Islands, Capitol Hill, Saipan MP 96950, 34 p.

Sako, M.K., Trusdell, F.A., Koyanagi, R.Y., Kojima, G., and Moore, R.B., 1995, Volcanic investigations in the Commonwealth of the Northern Mariana islands, April to May 1994: U.S. Geological Survey Open-File Report 94-705, 57 p.

Smithsonian Institution, 1993, Pagan: Bulletin of the Global Volcanism Network, v. 18, nos. 3,5 and 8 .

Comprehensive References

$\underline{2006}$ Eruption

Marske, J.P., Trusdell, F.A., Garcia, M.O., and Pietruszka, A.J., 2007, Island-arc magmatic processes beneath South Pagan volcano, Northern Mariana Islands [abs.]: Eos, Transactions, American Geophysical Union, v. 88, no. 52, Fall Meeting Supplement, Abstract V43D-1640.

Smithsonian Institution, 2007, Pagan: Bulletin of the Global Volcanism Network, v. 32, no. 1.

\section{Anatahan}

0804-20=

Comprehensive References

1990 Unrest

Moore, R.B., Koyanagi, R.Y., Sako, M.K., Trusdell, F.A., Kojima, G., Ellorda, R.L., and Zane, S., 1994, Volcanologic investigations in the Commonwealth of the 
Northern Mariana Islands, September-October 1990: U.S. Geological Survey Open-File Report 91-320, 31 p.

Rowland, S.K., Lockwood, J.P, Trusdell, F.A., Moore, R.B., Sako, M.K., Koyanagi, R.Y, and Kojima, G., 2005, Anatahan, Northern Mariana Islands-Reconnaissance geological observations during and after the volcanic crisis of spring 1990, and monitoring prior to the May 2003 eruption: Journal of Volcanology and Geothermal Research, v. 146, p. 26-59,

Sako, M.K., Trusdell, F.A., Koyanagi, R.Y., Kojima, G., and Moore, R.B., 1995, Volcanic investigations in the Commonwealth of the Northern Mariana Islands, April to May 1994: U.S. Geological Survey Open-File Report 94-705, 57 p.

Smithsonian Institution, 1990, Anatahan: Bulletin of the Global Volcanism Network, v. 15 , nos. 3, 4, 6, 9 and 10.

Comprehensive References

1993 Unrest

Smithsonian Institution, 1993, Anatahan: Bulletin of the Global Volcanism Network, v. 18 , nos. 5 and 8.

Selected References

$\underline{2003}$ Eruption

Hilton, D.R., Pallister, J.S., and Pua, R.M., eds., 2005, The 2003 eruption of Anatahan volcano, Commonwealth of the Northern Mariana Islands: Journal of Volcanology and Geothermal Research, v. 146, p. 1-256.

Smithsonian Institution, 2003, Anatahan: Bulletin of the Global Volcanism Network, v. 28, nos. 4, 5, 6, 7 and 9.

Comprehensive References

2004-2005 Eruption

Hendricks, T.P., 2006, Early detection of the 5 April 2005 Anatahan Volcano eruption using the Guam WSR-88D: NWA Journal of Operational Meteorology, v. EJ8, 11 p.

Smithsonian Institution, 2004, Anatahan: Bulletin of the Global Volcanism Network, v. 29 , nos. $4,5,8$ and 12 .

Smithsonian Institution, 2005, Anatahan: Bulletin of the Global Volcanism Network, v. 30 , nos. 2, 4, 7 and 8 . 
Comprehensive References

$\underline{2006}$ Eruption

Smithsonian Institution, 2006, Anatahan: Bulletin of the Global Volcanism Network, v. 31 , no. 5 .

Comprehensive References

$\underline{2007 \text { Eruption }}$

Smithsonian Institution, 2007, Anatahan: Bulletin of the Global Volcanism Network, v. 32 , nos. 2 and 12.

Comprehensive References

2008 Unrest

MODIS Rapid Response Team, NASA Earth Observatory Homepage, [available at http://earthobservatory.nasa.gov/, last accessed September 1, 2008].

Smithsonian Institution, 2008, Anatahan: Bulletin of the Global Volcanism Network, v. 33 , no. 12.

\section{Ahyi \\ 0804-141}

Comprehensive References

\section{Eruption}

Embley, R.W., Baker, E.T., Chadwick, W.W., Jr., Lupton, J.E., Resing, J.A., Massoth, G.J., and Nakamura, K., 2004, Explorations of Mariana Arc volcanoes reveal new hydrothermal systems: Eos, Transactions, American Geophysical Union, v. 85, no. 4 , p. 37-44.

Smithsonian Institution, 2001, Ahyi: Bulletin of the Global Volcanism Network, v. 26, no. 5.

\section{Sarigan}

0804-192

Comprehensive References

\section{Unrest}

Heeszel, D.S., Wiens, D.A., Shore, P.J., Shiobara, H., and Sugioka, H., 2005, Earthquake swarms detected by the Mariana SUBFAC seismograph deployment: Submarine volcanic activity and tectonic deformation of the Mariana microplate [abs.]: Eos 
Transactions, American Geophysical Union, v. 86, no. 52, Fall Meeting

Supplement, Abstract T53A-1406.

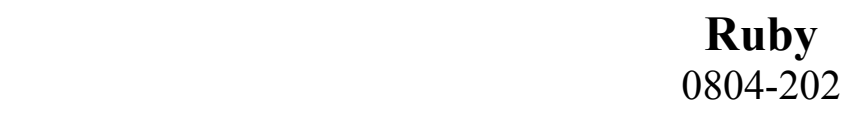

Comprehensive References

1995 Eruption

Smithsonian Institution, 1995, Ruby: Bulletin of the Global Volcanism Network, v. 20, no. 10.

\section{Selected References}

\section{NW Rota-1}

0804-211

\section{4-2008 Eruption}

Chadwick, W.W., Jr., Cashman, K.V., Embley, R.W., Matsumoto, H., Dziak R.P., de Ronde, C.E.J., Lau, T.K., Deardorff, N.D., and Merle, S.G., 2008, Direct video and hydrophone observations of submarine explosive eruptions at NW Rota-1 volcano, Mariana arc: Journal of Geophysical Research, v. 113, 23 p. doi:10.1029/2007JB005215.

Deardroff, N., Cashman, K.V., Chadwick, W.W., and Embley, R.W., 2007, Plume and pyroclast dynamics observed during a submarine explosive eruption at NW Rota1, Mariana Arc [abs.]: Eos, Transactions, American Geophysical Union, v. 85, no. 52, Fall Meeting Supplement, Abstract V24B-07.

Embley, R.W., Baker, E.T., Chadwick, W.W., Jr., Lupton, J.E., Resing, J.A., Massoth, G.J., and Nakamura, K., 2004, Explorations of Mariana Arc volcanoes reveal new hydrothermal systems: Eos, Transactions, American Geophysical Union, v. 85, p. 37,40 .

Embley, R.W., Chadwick, W.W., Jr., Baker, E.T., Butterfield, D.A., Resing, J.A., de Ronde, C.E.J., Tunnicliffe, V., Lupton, J.E., Juniper, S.K., Rubin, K.H., Stern, R.J., Lebon, G.T., Nakamura, K., Merle, S.G., Hein, J.R., Wiens, D.A., and Tamura, Y., 2006, Long-term eruptive activity at a submarine arc volcano: Nature Letters, v. 441, p. 494-497.

Lebon, G., Resing, J., Baker, E., Embley, R., and Lupton, J., 2004, Chemical characteristics of plumes above and around NW-Rota submarine volcano: Before and during the March 2004 eruption [abs.]: Eos, Transactions, American Geophysical Union, v. 85, no. 47, Fall Meeting Supplement, Abstract V41B1386. 
NOAA Vents Program, 2004, Submarine ring of fire 2004, Mariana arc submarine volcanoes, R/V Thomas G. Thompson Cruise TN167, March 27-April 17: NOAA Vents Program final cruise report, available at http://oceanexplorer.noaa.gov/explorations/04fire/logs/summary/media/marianas 2004cruisereport.pdf, last accessed September 9, 2008].

Okamura, K., Yanai, K., Sohrin, Y., Ishibashi, J., Watanabe, M., and Ura, T., 2004, In situ observations of dissolved Manganese in hydrothermal vent plumes at Mariana trough [abs.]: Eos, Transactions, American Geophysical Union, v. 85, no. 47, Fall Meeting Supplement, Abstract V41B-1391.

Resing, J.A., Lebon, G., Baker, E.T., Lupton, J.E., Embley, R.W., Massoth, G.J., Chadwick, W.W., Jr., and de Ronde, C.E.J., 2007, Venting of acid-sulfate fluids in a high-sulfidation setting at NW Rota-1 submarine volcano on the Mariana Arc: Economic Geology, v. 102, no. 6, p. 1047-1061.

Stern, R.J., Basu, N.K., Kohut, E., Hein, J., and Embley, R.W., 2004, Petrology and geochemistry of igneous rocks collected in association with ROV investigations of three hydrothermal sites in the Mariana Arc: NW Rota-1, E. Diamante, and NW Eifuku [abs.]: Eos, Transactions, American Geophysical Union, v. 85, no. 47, Fall Meeting Supplement, Abstract V43F-07. 